\title{
CHEMICAL ANALYSES OF WATER SAMPLES AND GEOPHYSICAL LOGS FROM CORED TEST HOLES DRILLED IN THE CENTRAL OKLAHOMA AQUIFER, OKLAHOMA
}

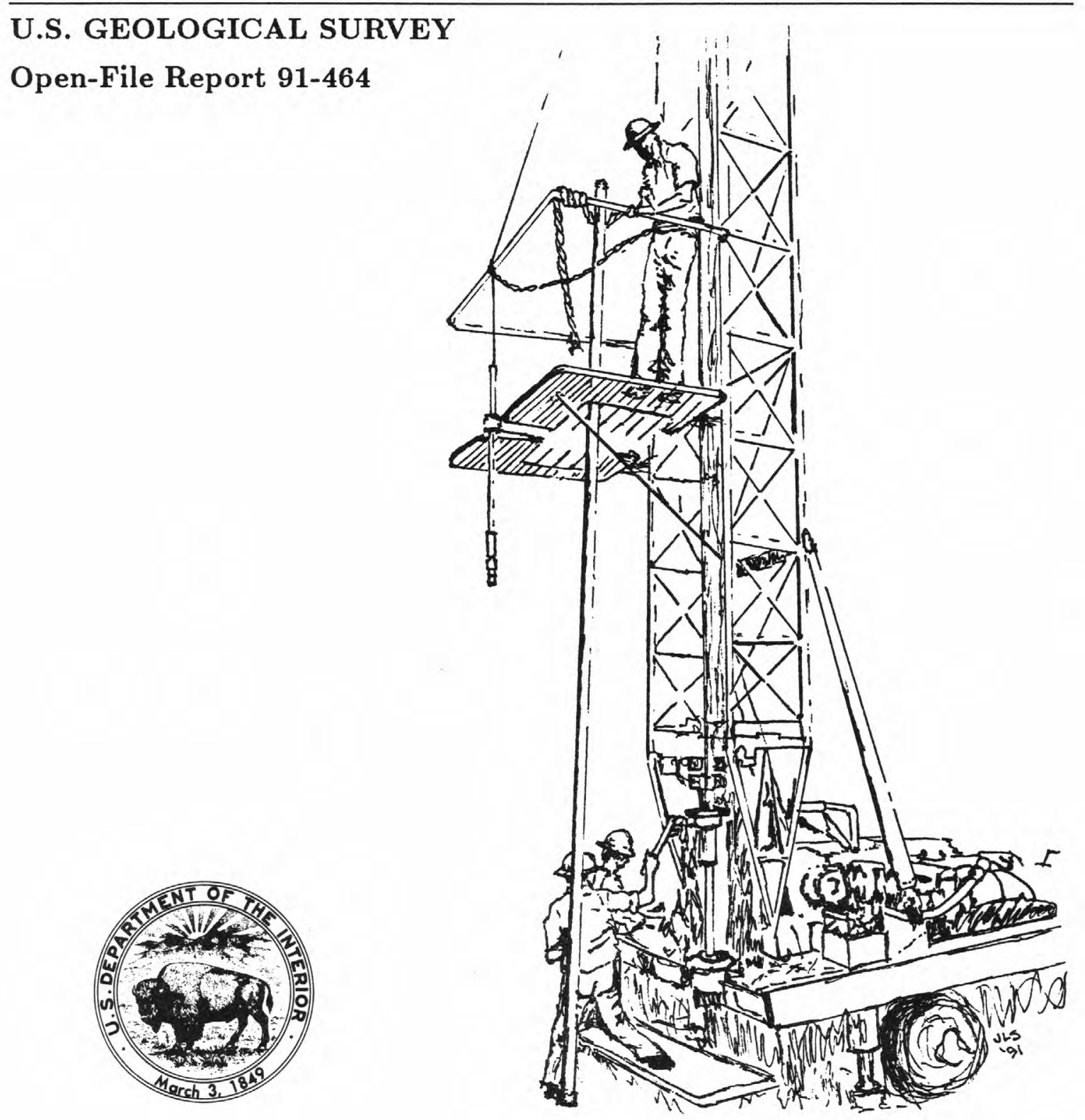

Test-hole drilling in the Central Oklahoma aquifer 



\section{CHEMICAL ANALYSES OF WATER SAMPLES AND GEOPHYSICAL LOGS FROM CORED TEST HOLES DRILLED IN THE CENTRAL OKLAHOMA AQUIFER, OKLAHOMA}

By Jamie L. Schlottmann and Ron A. Funkhouser

U.S. GEOLOGICAL SURVEY

Open-File Report 91-464

Prepared in cooperation with the ASSOCIATION OF CENTRAL OKLAHOMA GOVERNMENTS

$$
\begin{gathered}
\text { Oklahoma City, Oklahoma } \\
1991
\end{gathered}
$$




\section{U.S. DEPARTMENT OF THE INTERIOR}

MANUEL LUJAN, JR., Secretary

U.S. GEOLOGICAL SURVEY

Dallas L. Peck, Director

For additional information

write to:

District Chief

U.S. Geological Survey

Building 7, Broadway Executive Park $202 \mathrm{NW} 66^{\text {th }}$ Street

Oklahoma City, Oklahoma 73116
Copies of this report can

be purchased from:

Books and Open-File Reports

U.S. Geological Survey

Federal Center

Box 25425

Denver, Colorado 80225 


\section{CONTENTS}

Page

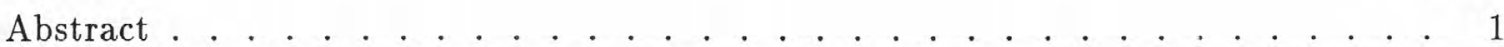

Introduction . . . . . . . . . . . . . . . . . . . . . . . 1

Purpose and scope . . . . . . . . . . . . . . . . . . . 3

Description and hydrogeology of the study unit . . . . . . . . . . . . . . . 3

Description of the NOTS Drilling Project . . . . . . . . . . . . . . 6

Explanation of the local identifier . . . . . . . . . . . . . . . 8

Water chemistry . . . . . . . . . . . . . . . . 8

Field methods . . . . . . . . . . . . . . . . . . . . 8

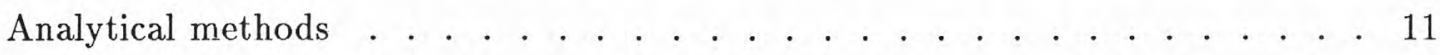

Analytical results . . . . . . . . . . . . . . . . . . 15

Geophysical $\log s$. . . . . . . . . . . . . . . . . . . . . . . 15

Methods . . . . . . . . . . . . . . . . 15

Mechanical $\log$. . . . . . . . . . . . . . . 15

Nuclear $\operatorname{logs}$. . . . . . . . . . . . . . . . . . . . . 15

Electric logs . . . . . . . . . . . . . . . . . . . 16

Description of $\log$ presentation . . . . . . . . . . . . . . . . 18

References cited ...................... 37

\section{ILLUSTRATIONS}

Figure 1-2. Maps showing:

1. Location of the Central Oklahoma aquifer and the study unit . . . . . 2

2. Geographic features of study unit and location of test-holes drilled in the Central Oklahoma aquifer ............ 4

3. Geologic map of central Oklahoma . . . . . . . . . . . . . . 5

4. Simplified diagram of packer and pump assembly to isolate and sample water from sandstone layers intercepted by the NOTS test holes . . . . . . . . . . . . . . . . . . . 9 
Figure 5-13. Geophysical logs for:

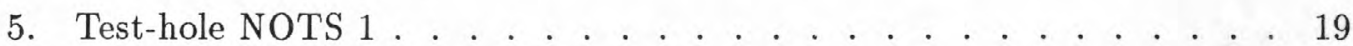

6. Test-hole NOTS $1 \mathrm{~A}$. . . . . . . . . . . . . . . . . . . . . . 21

7. Test-hole NOTS 2 . . . . . . . . . . . . . . . . . . 23

8. Test-hole NOTS 3 . . . . . . . . . . . . . . . . . . . 25

9. Test-hole NOTS 4 . . . . . . . . . . . . . . . . . . . . . . . . 27

10. Test-hole NOTS 5. . . . . . . . . . . . . . . . . . 29

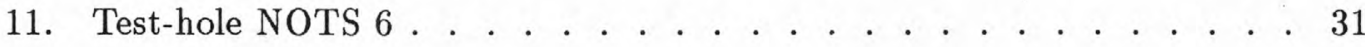

12. Test-hole NOTS 7 . . . . . . . . . . . . . . . . . . 33

13. Test-hole NOTS 7A . . . . . . . . . . . . . . . . . . . . 35

\section{TABLES}

Table 1. Correlation of major chronostratigraphic units, geologic units, and geohydrologic categories in central Oklahoma . . . . . . . . 6

2. Description of NOTS test holes and number of water-chemistry samples taken from intervals in each hole . . . . . . . . . . 7

3. Description of water-chemistry samples collected from NOTS test holes . . . . . . . . . . . . . . . . . . . 10

4. Summary of pumps and pumping times used to develop sampling intervals and collect water samples for NOTS test holes . . . . . 12

5. Field procedures for collection and preservation of water samples for laboratory analysis . . . . . . . . . . . . . . . . . . . 13

6. Listing of analytical methods used at the National Water Quality Laboratory . . . . . . . . . . . . . . . . 39

7. Properties and major constituents of water from NOTS test holes . . . 43

8-13. Listings of:

8. Concentrations of trace elements in water for NOTS test holes . . . . 47

9. Concentrations of arsenic in water from NOTS test holes . . . . . . 50

10. Concentrations of chromium in water from NOTS test holes . . . . . 51

11. Concentrations of selenium in water from NOTS test holes . . . . . . 52 
12. Concentrations of selected radionuclides in water from NOTS test holes . . . . . . . . . . . . . . . . . 53

13. $\delta$-values in permil for stable isotopes in water from NOTS test holes . . . . . . . . . . . . . . 58 


\title{
METRIC CONVERSION FACTORS
}

For readers who prefer metric (International System) units rather than inch-pound units (used in this report), the following conversion factors may be applied:

\begin{tabular}{rcl}
\hline Multiply inch-pound unit & \multicolumn{1}{c}{ By } & To obtain metric unit \\
\hline foot & 0.3048 & meter \\
gallon & 0.003785 & cubic meter \\
gallons per minute & 0.0000631 & cubic meters per second \\
\hline
\end{tabular}

Temperature in degrees Celcius $\left({ }^{\circ} \mathrm{C}\right)$ can be converted to degrees Fahrenheit $\left({ }^{\circ} \mathrm{F}\right)$ as follows:

$$
{ }^{\circ} \mathrm{F}=\left(1.8 \mathrm{X}{ }^{\circ} \mathrm{C}\right)+32
$$

\begin{abstract}
ALTITUDE DATUM
Sea level: In this report "sea level" refers to the National Geodetic Vertical Datum (NGVD) of 1929-a geodetic datum derived from a general adjustment of the first-order level nets of both the United States and Canada, formerly called Sea Level Datum of 1929.
\end{abstract}




\title{
CHEMICAL ANALYSES OF WATER SAMPLES AND GEOPHYSICAL LOGS FROM CORED TEST HOLES DRILLED IN THE CENTRAL OKLAHOMA AQUIFER, OKLAHOMA
}

\author{
By Jamie L. Schlottmann and Ron A. Funkhouser
}

\begin{abstract}
Chemical analyses of water from eight test holes and geophysical logs for nine test holes drilled in the Central Oklahoma aquifer are presented. The test holes were drilled to investigate local occurrences of potentially toxic, naturally occurring trace substances in ground water. These trace substances include arsenic, chromium, selenium, residual alphaparticle activities, and uranium. Eight of the nine test holes were drilled near wells known to contain large concentrations of one or more of the naturally occurring trace substances. One test hole was drilled in an area known to have only small concentrations of any of the naturally occurring trace substances.

Water samples were collected from one to eight individual sandstone layers within each test hole. A total of 28 water samples, including four duplicate samples, were collected. The temperature, $\mathrm{pH}$, specific conductance, alkalinity, and dissolved-oxygen concentrations were measured at the sample site. Laboratory determinations included major ions, nutrients, dissolved organic carbon, and trace elements (aluminum, arsenic, barium, beryllium, boron, cadmium, chromium, hexavalent chromium, cobalt, copper, iron, lead, lithium, manganese, mercury, molybdenum, nickel, selenium, silver, strontium, vanadium and zinc). Radionuclide activities and stable isotope $\delta$ values also were determined, including: gross-alpha-particle activity, gross-beta-particle activity, radium-226, radium-228, radon-222, uranium-234, uranium-235, uranium-238, total uranium, carbon-13/carbon-12, deuterium/hydrogen-1, oxygen-18/oxygen-16, and sulfur-34/sulfur-32. Additional analyses of arsenic and selenium species are presented for selected samples as well as analyses of density and iodine for two samples, tritium for three samples, and carbon-14 for one sample.

Geophysical logs for most test holes include caliper, neutron, gamma-gamma, naturalgamma logs, spontaneous potential, long- and short-normal resistivity, and single-point resistance. Logs for test-hole NOTS 7 do not include long- and short-normal resistivity, spontaneous-potential, or single-point resistivity. Logs for test-hole NOTS 7A include only caliper and natural-gamma logs.
\end{abstract}

\section{INTRODUCTION}

Studies of water and rock characteristics associated with arsenic, chromium, residual alpha-particle activity, selenium, and uranium in ground water of the Central Oklahoma aquifer, Oklahoma are part of the National Water-Quality Assessment (NAWQA) Program of the U.S. Geological Survey. The long-term goals of the NAWQA program are to: 


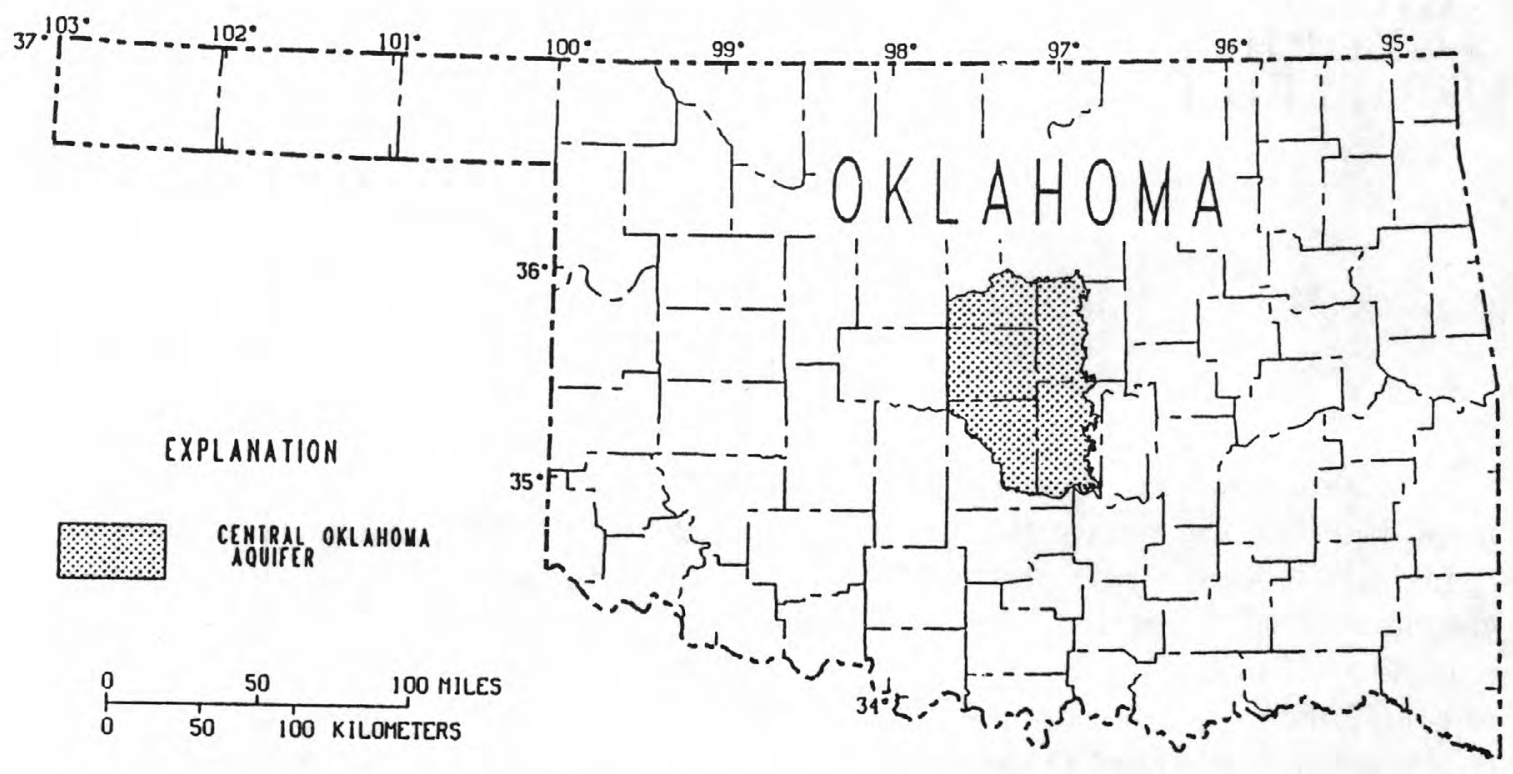

Figure 1.-Location of the Central Oklahoma aquifer and the study unit.

(1) Provide a nationally consistent description of current water-quality conditions for a large part of the Nation's water resources,

(2) Define long-term trends (or lack of trends) in water quality, and

(3) Identify, describe, and explain, as possible, the major factors that affect the observed water-quality conditions and trends.

The results of the NAWQA Program will be made available to water managers, policy makers, and the public, and will provide an improved scientific basis for evaluating the effectiveness of water-quality management programs (Hirsch and others, 1988).

The Central Oklahoma aquifer (fig. 1) was selected for study because it is a major source of water in central Oklahoma and because it has several known or suspected water-quality problems (Parkhurst and others, 1989). Studies of the water-quality problems, including local occurrences of potentially toxic trace elements, address goal three of the NAWQA program.

Arsenic, chromium, residual alpha-particle activities, selenium, and uranium occur naturally in the aquifer, and in some areas are present in large concentrations. These potentially toxic naturally occurring trace substances (NOTS) appear to be more common in some parts of the aquifer than in others. Existing ground-water-quality data (through 1987) for the Central Oklahoma aquifer were reviewed at the inception of the NAWQA 
project by Parkhurst and others (1989). Arsenic and chromium commonly exceeded the U.S. Environmental Protection Agency's primary drinking-water standard (1986) of $50 \mathrm{mi}$ crograms per liter $(\mu \mathrm{g} / \mathrm{L})$ in water from wells deeper than 300 feet, and in some parts of the aquifer selenium commonly exceeded the standard of $10 \mu \mathrm{g} / \mathrm{L}$ in wells over 100 feet in depth. Residual alpha-particle activity commonly exceeded the standard of 15 picocuries per liter $(\mathrm{pCi} / \mathrm{L})$, and uranium concentrations were commonly large in water from wells in the eastern part of the study area.

A cooperative effort between the U.S. Geological Survey's Water Resources and Geologic Divisions was organized to drill cored test holes (fig. 2) in order to evaluate the sources of and processes controlling the mobilization of the NOTS. The chemical composition of the rocks has been reported by Mosier and others (1990) and an additional report describing the mineralogy and petrology of the rock cores has been presented by Breit and others (1990). The study of the NOTS in the western part of the aquifer was made in cooperation with the Association of Central Oklahoma Governments.

\section{Purpose and Scope}

The purpose of this report is to present results of chemical and isotopic analyses of water samples collected from test holes that were drilled in the Central Oklahoma aquifer, and to publish the geophysical logs of the test holes. No interpretations of the data are presented.

\section{Description and Hydrogeology of the Study Unit}

The study-unit boundary is the perimeter of the Central Oklahoma aquifer (fig. 2) as defined by Parkhurst and others (1989). The Central Oklahoma aquifer extends from the Canadian River on the south to the Cimarron River on the north and from the OklahomaCanadian and Logan-Kingfisher County lines on the west to the eastern limit of the outcrop of the Chase, Council Grove, and Admire Groups on the east. The study unit contains all of Cleveland and Oklahoma Counties and parts of Lincoln, Logan, and Pottawatomie Counties. The base of the aquifer and thus the study unit is defined as the lower limit of ground water containing less than 5,000 milligrams per liter dissolved solids. The boundary, defined by the increase in dissolved-solids concentration, ranges in depth from 100 to about 1,000 feet and is referred to as the base of fresh water.

The Central Oklahoma aquifer includes Quaternary alluvial and terrace deposits and underlying Permian-age units including the Garber Sandstone, the Wellington Formation, and the Chase, Council Grove, and Admire Groups (fig. 3). This study is restricted to the Permian-age rocks in the aquifer and the overlying Hennessey Group. The Permian-age part of the aquifer is overlain in the western part of the study unit by the Permian-age Hennessey Group, which acts as a confining layer. In the east the aquifer overlies the Pennsylvanian-age Vanoss Group. Transmissivities of Permian-age rocks within the Central Oklahoma aquifer are larger than transmissivities for equivalent-age rocks outside of the aquifer boundary (Parkhurst and others, 1989). The stratigraphic relation between the geologic units in the study unit are shown in table 2 with the corresponding geohydrologic categories. All 


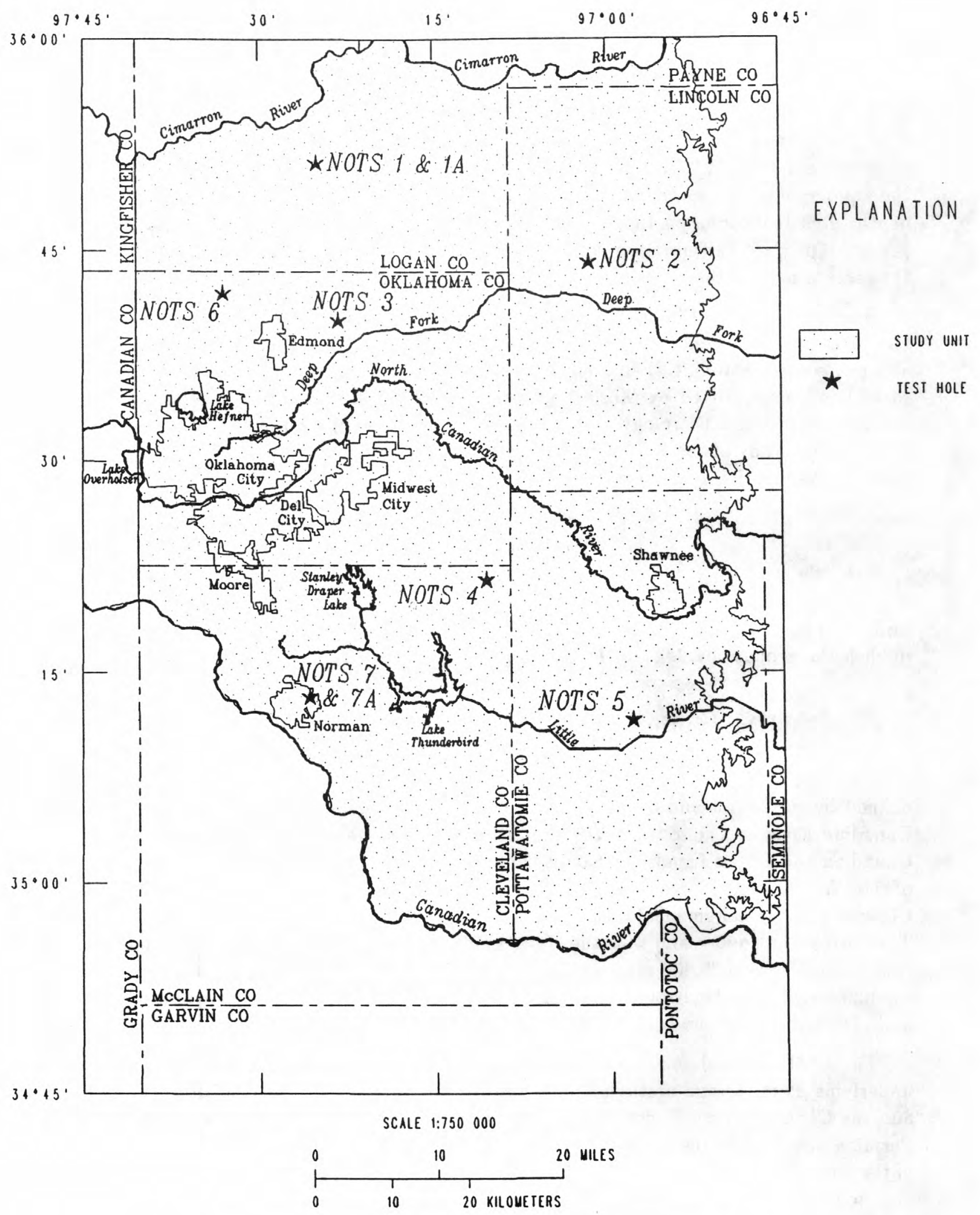

Figure 2.-Geographic features of study unit and location of test-holes drilled in the Central Oklahoma aquifer. 


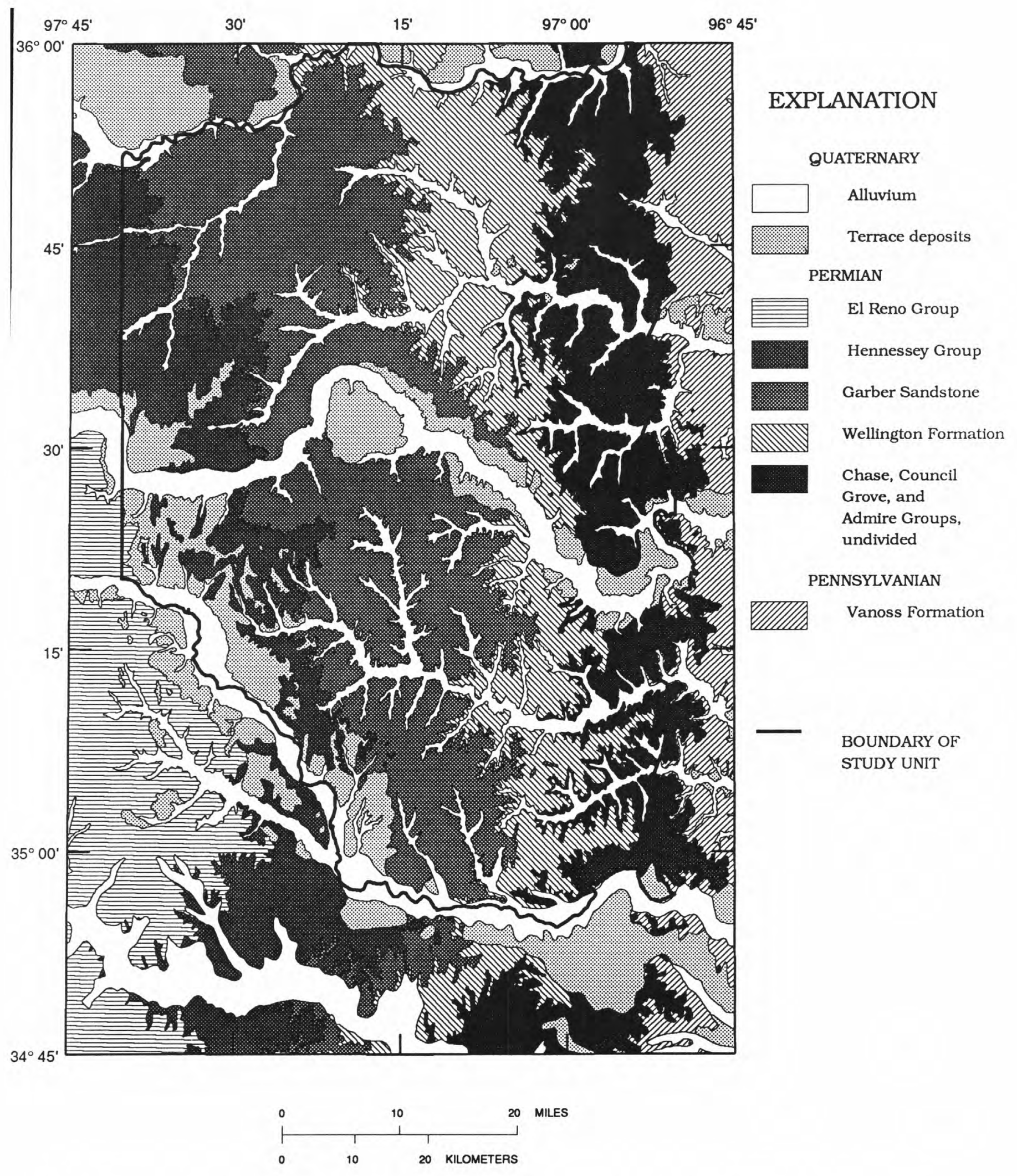

Figure 3.-Geologic map of central Oklahoma (modified from Bingham and Moore, 1975, and Hart, 1974). 
Permian rocks in the study unit dip to the west-southwest at a gradient of approximately 50 feet per mile (Parkhurst and others, 1989).

Table 1.-Correlation of major chronostratigraphic units, geologic units, and geohydrologic categories in central Oklahoma (from Parkhurst and others, 1989, p. 8, table 1)

\begin{tabular}{|c|c|c|c|}
\hline Erathem & System & Geologic unit & $\begin{array}{c}\text { Geohydrologic } \\
\text { category }\end{array}$ \\
\hline \multirow{2}{*}{ Cenozoic } & \multirow{2}{*}{ Quaternary } & Alluvium & \multirow{2}{*}{ Alluvium-Terrace } \\
\hline & & Terrace deposits & \\
\hline \multirow{8}{*}{ Paleozoic } & \multirow{7}{*}{ Permian } & El Reno Group & El Reno \\
\hline & & Hennessey Group & Hennessey \\
\hline & & Garber Sandstone & \multirow{2}{*}{$\begin{array}{c}\text { Garber-Wellington } \\
\text { Shallow } \\
\text { Medium-depth } \\
\text { Deep }\end{array}$} \\
\hline & & Wellington Formation & \\
\hline & & Chase Group & \multirow{3}{*}{ Chase-Admire } \\
\hline & & Council Grove Group & \\
\hline & & Admire Group & \\
\hline & Pennsylvanian & Vanoss Formation & Vanoss \\
\hline
\end{tabular}

\section{Description of the NOTS Drilling Project}

Nine test holes were cored at various locations in the aquifer to study the water-rock interactions that lead to increased concentrations of arsenic, chromium, selenium, residual alpha-particle activity, and uranium in the ground water (fig. 2). One of the test holes, NOTS 4, was located in an area of generally good water quality; the remaining eight were located in areas known to have high concentrations of one or more of the potentially toxic substances. The lithology of rock core collected from each test hole was briefly described at the site before the core was labeled and placed in core boxes. Each test hole was logged geophysically. Water was collected from one to eight water-producing sandstone layers penetrated by eight of the test holes and chemically analyzed. The rock core collected from eight of the test holes was split and one half was sampled for chemical and petrographic analyses; the other half was reserved for detailed description of lithology and sedimentology. One of the test holes, NOTS 1, was not sampled because of hole instability. Another test hole, NOTS 1A, was drilled adjacent to NOTS 1 and was sampled. The test holes are described in table 1. 
Table 2.- Description of NOTS test holes and number of water-chemistry samples taken from intervals in each hole [Open-hole water level in feet below land surface; Geologic units intercepted: Hennessey, Hennessey Group; Garber, Garber Sandstone; Wellington, Wellington Formation; Chase, Chase-Council Grove-Admire Groups. Number of duplicate water samples collected at each test hole in addition to the actual samples are shown in parentheses next to number of water samples collected]

\begin{tabular}{|c|c|c|c|c|c|c|c|c|c|}
\hline $\begin{array}{l}\text { Well } \\
\text { name }\end{array}$ & $\begin{array}{c}\text { Local } \\
\text { identifier }\end{array}$ & Latitude & Longitude & County & $\begin{array}{c}\text { Altitude } \\
\text { (feet } \\
\text { above } \\
\text { sea level) }\end{array}$ & $\begin{array}{c}\text { Depth } \\
\text { of hole } \\
\text { (feet) }\end{array}$ & $\begin{array}{c}\text { Open- } \\
\text { hole } \\
\text { water } \\
\text { level } \\
\text { (feet) }\end{array}$ & $\begin{array}{l}\text { Geologic units } \\
\text { intercepted }\end{array}$ & $\begin{array}{l}\text { Number } \\
\text { of water- } \\
\text { chem- } \\
\text { istry } \\
\text { samples }\end{array}$ \\
\hline NOTS 1 & $16 \mathrm{~N}-02 \mathrm{~W}-21 \mathrm{BAA} 2$ & 355120 & 0972500 & Logan & 1,050 & 272 & 50.5 & Garber & 0 \\
\hline NOTS $1 \mathrm{~A}$ & $16 \mathrm{~N}-02 \mathrm{~W}-21 \mathrm{BAA} 3$ & 355118 & 0972500 & Logan & 1,045 & 268 & 10.0 & Garber & 2 \\
\hline NOTS 2 & $15 \mathrm{~N}-03 \mathrm{E}-31$ BAA 2 & 354418 & 0970135 & Lincoln & 900 & 277 & 42.0 & Chase & 1 \\
\hline NOTS 3 & $14 \mathrm{~N}-02 \mathrm{~W}-23 \mathrm{CCA} 1$ & 354012 & 0972310 & Oklahoma & 1,035 & 195 & 36.0 & Garber & $2(1)$ \\
\hline NOTS 4 & $10 \mathrm{~N}-01 \mathrm{E}-11 \mathrm{BBB} 1$ & 352142 & 0971035 & Cleveland & 1,145 & 291 & 31.0 & Garber, Wellington & 4 \\
\hline NOTS 5 & $08 \mathrm{~N}-03 \mathrm{E}-03$ DAA 1 & 351142 & 0965801 & Pottawatomie & 945 & 238 & 18.5 & Chase & $3(1)$ \\
\hline NOTS 6 & $14 \mathrm{~N}-03 \mathrm{~W}-07$ DAA 2 & 354208 & 0973302 & Oklahoma & 1,085 & 587 & 46.0 & Garber & $8(1)$ \\
\hline NOTS 7 & $09 \mathrm{~N}-02 \mathrm{~W}-29$ DCA 5 & 351315 & 0972543 & Cleveland & 1,172 & 456 & 74.0 & Hennessey, Garber & 1 \\
\hline NOTS $7 \mathrm{~A}$ & $09 \mathrm{~N}-02 \mathrm{~W}-29 \mathrm{DCA} 6$ & 351315 & 0972542 & Cleveland & 1,172 & 631 & 97.0 & Hennessey, Garber & $3(1)$ \\
\hline
\end{tabular}




\section{Explanation of the Local Identifier}

The locations of the test holes are specified by latitude and longitude to the nearest second and by a local identifier, which is based on the public land survey. The local identifier includes the township and range followed by the section and a series of letters that designate the quarter-section subdivisions from largest to smallest. The order of the quarter-section subdivisions is opposite of that used in the public land survey. A sequence number is added to make the local identifier unique in the U.S. Geological Survey data base. As illustrated in the following diagram, the public land survey description of the site indicated by the dot is NE $1 / 4 \mathrm{SW} 1 / 4 \mathrm{SE} 1 / 4$ sec. 29 , T. $09 \mathrm{~N}$., R. $02 \mathrm{~W}$., which is denoted by the local identifier $09 \mathrm{~N}-02 \mathrm{~W}-29 \mathrm{DCA}$. If the sequence number is 5 , the complete identifier is $09 \mathrm{~N}-02 \mathrm{~W}-29 \mathrm{DCA} 5$.

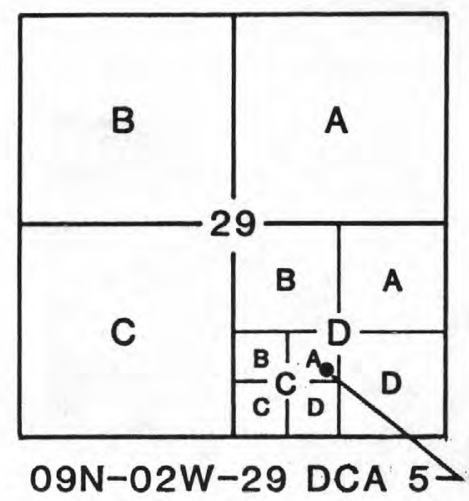

\section{WATER CHEMISTRY}

\section{Field Methods}

When possible, ground water from sandstone layers penetrated by the test holes was sampled for chemical analysis. In order to sample water from an individual sandstone layer, the layer was isolated using two inflatable packers separated by 5 or 10 feet of stainless steel well screen and enough galvanized pipe to make the isolated interval span the entire thickness of the sandstone (fig. 4). The centers of the packers generally were set 2 to 3 feet below the top and above the bottom of each sandstone layer. They were set there because the interbedded mudstone layers sloughed rapidly in the open hole, making it impossible to inflate the packers against the mudstone above and below the sand. For some samples, one of the packers was set near the edge of the next adjacent sandstone layer because the shortest packer-assembly length was too long to fit within the sandstone to be sampled. Table 3 describes the water samples collected from the test holes. The sampling depth is the depth of the center of the sampling interval below land surface. The sample depth interval is designated as the distance in feet below land surface of the vertical centers of the upper and lower packer.

Before inserting the sampling pump, each interval was developed until the produced water was clear. The intervals were developed by airlifting or another pumping method if airlifting was not possible. Some intervals did not produce clear water. If the water was not clear, the interval was pumped as long as possible (1.5 to 32 hours, depending on hole stability and available work hours) before inserting the sampling pump. Samples were collected using either a submersible electric pump, a pump jack, or a teflon bladder pump, depending on the rate at which the sand would produce water and the water level 


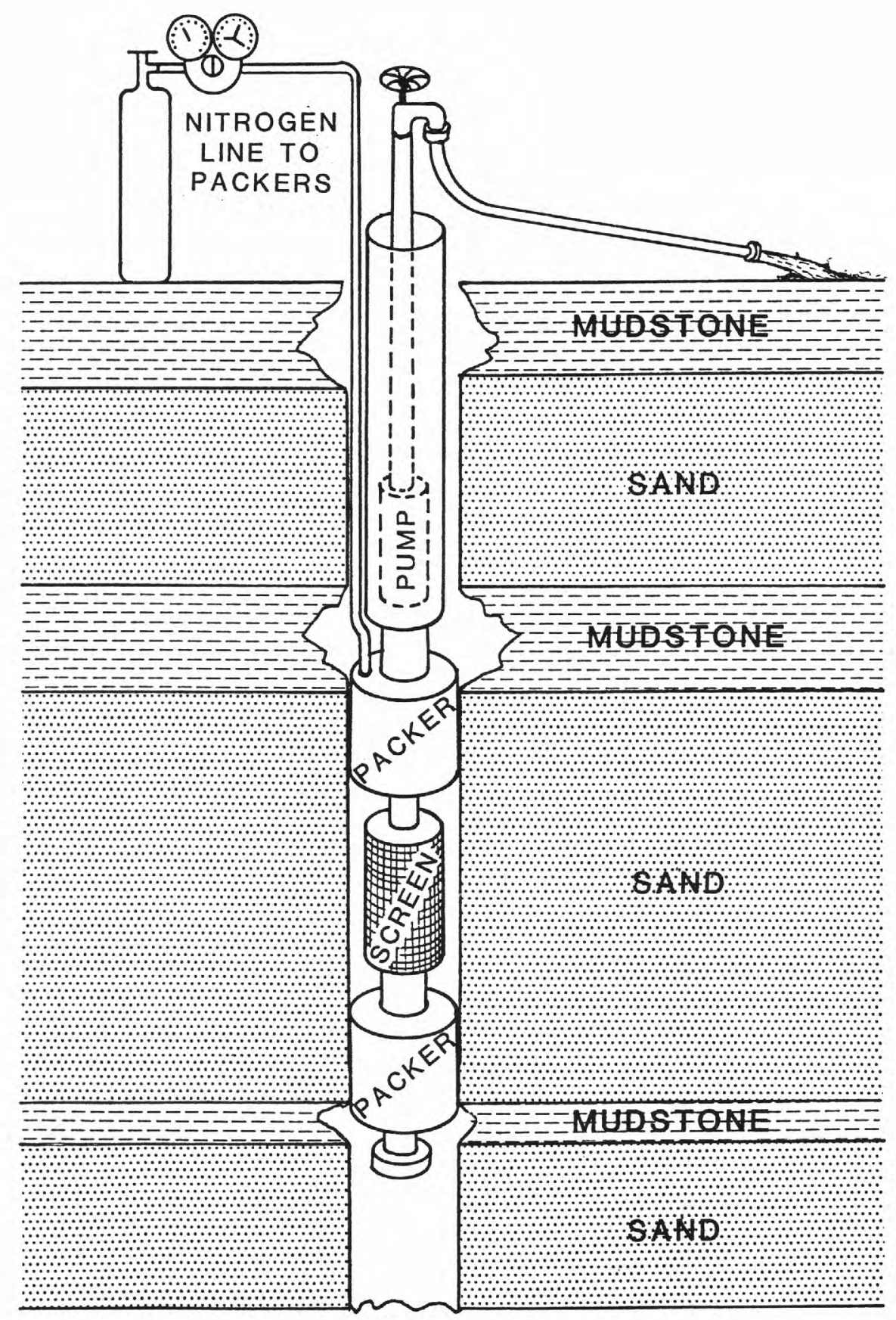

Figure 4.- Simplified diagram of packer and pump assembly to isolate and sample water from sandstone layers intercepted by the NOTS test holes. 
Table 3.-Description of water-chemistry samples collected from NOTS test holes [CST, central standard time; Geologic units sampled: Garber, Garber Sandstone; Wellington, Wellington Formation; Chase, Chase-Council Grove-Admire Groups; Interval water level in feet below land surface]

\begin{tabular}{|c|c|c|c|c|c|c|c|}
\hline $\begin{array}{l}\text { Test-hole } \\
\text { name }\end{array}$ & $\begin{array}{l}\text { Local } \\
\text { identifier }\end{array}$ & $\begin{array}{r}\text { Sampling } \\
\text { depth } \\
\text { (feet) } \\
\end{array}$ & $\begin{array}{c}\text { Sampling } \\
\text { date }\end{array}$ & $\begin{array}{c}\text { Sam- } \\
\text { pling } \\
\text { time } \\
(\mathrm{CST})\end{array}$ & $\begin{array}{c}\text { Sample depth } \\
\text { interval } \\
\text { (feet) }\end{array}$ & $\begin{array}{l}\text { Geologic } \\
\text { unit } \\
\text { sampled }\end{array}$ & $\begin{array}{r}\text { Interval } \\
\text { water } \\
\text { level } \\
\text { (feet) }\end{array}$ \\
\hline \multirow[t]{2}{*}{ NOTS $1 \mathrm{~A}$} & $16 \mathrm{~N}-02 \mathrm{~W}-21 \mathrm{BAA} 3$ & 176.0 & $04 / 21 / 88$ & 1600 & $166.0-186.0$ & Garber & 62.75 \\
\hline & & 229.0 & $04 / 20 / 88$ & 1300 & $210.0-248.0$ & Garber & 55.95 \\
\hline NOTS 2 & $15 \mathrm{~N}-03 \mathrm{E}-31$ BAA 2 & 106.4 & $05 / 11 / 88$ & 1300 & $96.4-116.0$ & Chase & 40.00 \\
\hline \multirow[t]{3}{*}{ NOTS 3} & $14 \mathrm{~N}-02 \mathrm{~W}-23 \mathrm{CCA} 1$ & 119.5 & $05 / 24 / 88$ & 1100 & $110.0-129.0$ & Garber & 60.75 \\
\hline & & 119.5 & $05 / 24 / 88$ & 1600 & $110.0-129.0$ & Garber & 60.75 \\
\hline & & 164.9 & $05 / 20 / 88$ & 1100 & $155.4-174.4$ & Garber & 62.28 \\
\hline \multirow[t]{4}{*}{ NOTS 4} & $10 \mathrm{~N}-01 \mathrm{E}-11 \mathrm{BBB} 1$ & 101.0 & $06 / 21 / 88$ & 1200 & $87.0-115.0$ & Garber & 51.60 \\
\hline & & 156.2 & $06 / 20 / 88$ & 1200 & $142.2-170.2$ & Garber & 49.19 \\
\hline & & 189.0 & $06 / 23 / 88$ & 1200 & $178.0-200.0$ & Garber & 25.90 \\
\hline & & 257.5 & $06 / 17 / 88$ & 1000 & $243.5-271.5$ & Wellington & 89.40 \\
\hline \multirow[t]{4}{*}{ NOTS 5} & $08 \mathrm{~N}-03 \mathrm{E}-03 \mathrm{DAA} 1$ & 62.0 & $07 / 06 / 88$ & 1000 & $48.0-76.0$ & Chase & 18.52 \\
\hline & & 62.0 & $07 / 06 / 88$ & 1400 & $48.0-76.0$ & Chase & 18.52 \\
\hline & & 131.0 & $07 / 05 / 88$ & 1000 & $127.0-155.0$ & Chase & 30.83 \\
\hline & & 183.5 & $07 / 01 / 88$ & 1000 & $169.5-197.5$ & Chase & 29.55 \\
\hline \multirow[t]{9}{*}{ NOTS 6} & $14 \mathrm{~N}-03 \mathrm{~W}-07$ DAA 2 & 106.2 & $11 / 02 / 88$ & 900 & $96.4-116.8$ & Garber & 61.22 \\
\hline & & 141.0 & $11 / 08 / 88$ & 1100 & $121.4-160.5$ & Garber & 64.06 \\
\hline & & 180.8 & $11 / 07 / 88$ & 1500 & $161.2-200.3$ & Garber & 72.64 \\
\hline & & 180.8 & $11 / 07 / 88$ & 1300 & $161.2-200.3$ & Garber & 72.64 \\
\hline & & 222.8 & $11 / 04 / 88$ & 900 & $203.2-242.3$ & Garber & 74.04 \\
\hline & & 276.2 & $11 / 01 / 88$ & 900 & $266.0-286.0$ & Garber & 114.50 \\
\hline & & 296.2 & $10 / 28 / 88$ & 1500 & $286.0-306.4$ & Garber & 120.30 \\
\hline & & 327.1 & $11 / 03 / 88$ & 1300 & $307.5-346.6$ & Garber & 110.13 \\
\hline & & 475.1 & $12 / 07 / 88$ & 900 & $456.0-494.2$ & Garber & 168.88 \\
\hline NOTS 7 & $09 \mathrm{~N}-02 \mathrm{~W}-29 \mathrm{DCA} 5$ & 262.7 & $02 / 17 / 89$ & 1100 & $229.2-276.2$ & Garber & 209.34 \\
\hline \multirow[t]{4}{*}{ NOTS 7A } & $09 \mathrm{~N}-02 \mathrm{~W}-29 \mathrm{DCA} 6$ & 330.1 & $07 / 20 / 89$ & 1300 & $316.6-343.6$ & Garber & 250.00 \\
\hline & & 407.5 & $08 / 08 / 89$ & 1500 & $397.0-418.0$ & Garber & 251.40 \\
\hline & & 480.0 & $09 / 20 / 89$ & 1200 & $460.0-500.0$ & Garber & 267.60 \\
\hline & & 480.0 & $09 / 20 / 89$ & 1500 & $460.0-500.0$ & Garber & 267.60 \\
\hline
\end{tabular}


for the sampled interval. With the exception of the samples from test-holes NOTS 2, 7 , and $7 \mathrm{~A}$, each sampled interval was purged of at least two bore volumes of water before sampling began. A bore volume was estimated to be the volume of the column of water between the packers plus the volume of water within the pipe above the packers. NOTS 2 produced too little water to purge an adequate volume before sampling. Problems with the pumps prevented adequate purging of the sampled intervals in NOTS 7 and $7 \mathrm{~A}$, with the the sample from NOTS 7 having the smallest volume purged. Data pertaining to the pumps and pumping times used to develop and sample each interval are summarized in table 4 .

After the sampling pump was inserted and the interval had been purged of at least one bore volume, specific conductance, water temperature, $\mathrm{pH}$, and dissolved-oxygen concentration were measured at 10- to 15-minute intervals. Measurements were made at the land surface in a flow-through cell by probes attached to portable meters. Water temperature was measured with the temperature sensor of the specific conductance meter.

Water sampling began after at least two consistent readings were obtained for water temperature, $\mathrm{pH}$, dissolved oxygen, and specific conductance for readings taken 10 to 15 minutes apart. Alkalinity was measured by an incremental titration (Knapton, 1985) using 0.1639 -Normal sulfuric acid on a filtered 25 -milliliter aliquot which was collected immediately after consistent readings were obtained.

Water samples were collected using methods described in Brown and others (1970) or by other methods recommended by the analyzing laboratories. Table 5 summarizes the sample collection and preservation procedures used, with the exception of a sample collected for carbon-14 determination.

The sample collected for carbon-14 determination for use in water-age estimation was prepared by filtering approximately 30 gallons of water under nitrogen into a stainless steel separatory funnel. The filters used included a 0.45 -micrometer pre-filter and a 0.2 micrometer membrane filter. Carbon-free sodium hydroxide and strontium chloride solutions were added to the filtered water to precipitate strontium carbonate. The precipitate was collected under nitrogen gas in a baked glass bottle. No preservatives were added.

\section{Analytical Methods}

All determinations, with the exception of those for arsenic species, selenium species, and carbon dating, were done by the U.S. Geological Survey National Water Quality Laboratory (NWQL). Specific conductance, $\mathrm{pH}$, major elements, nutrients, trace elements, and dissolved organic carbon concentrations were determined using standard methods described in Fishman and Friedman (1989). Radiochemical analyses were completed using standard methods as described in Thatcher and others (1977). Methods used by the NWQL for this study are listed in table 6 (at back of report).

Arsenic species concentration was determined at two laboratories. One sample from the deepest sampled interval in NOTS 6 was analyzed by the Branch of Regional Research, Western Region of the U.S. Geological Survey, Water Resources Division, Menlo Park, 
Table 4.-Summary of pumps and pumping times used to develop sampling intervals and collect water samples from NOTS test holes

[Sampling depth, center of sampling interval as depth below land surface; -, indicates data not available; pump types: Sub. elec., submersible electric; Bladder, stainless steel case with teflon bladder; gal/min, gallons per minute; Water clear: N, no, water still muddy, mostly opaque with sediment; Y, yes, water pumped until clear; M, mostly, water translucent with some suspended sediment]

\begin{tabular}{|c|c|c|c|c|c|c|c|c|c|}
\hline $\begin{array}{c}\text { Test-hole } \\
\text { name }\end{array}$ & $\begin{array}{c}\text { Local } \\
\text { identifier }\end{array}$ & $\begin{array}{c}\text { Sampling } \\
\text { depth } \\
\text { (feet) }\end{array}$ & $\begin{array}{c}\text { Developing } \\
\text { pump }\end{array}$ & $\begin{array}{c}\text { Devel- } \\
\text { oping } \\
\text { pumping } \\
\text { rate } \\
\text { (gal/min) }\end{array}$ & $\begin{array}{c}\text { Devel- } \\
\text { oping } \\
\text { pumping } \\
\text { time } \\
\text { (hours) }\end{array}$ & $\begin{array}{l}\text { Sampling } \\
\text { pump }\end{array}$ & $\begin{array}{l}\text { Sampling } \\
\text { pumping } \\
\text { rate } \\
\text { (gal } / \mathrm{min} \text { ) }\end{array}$ & $\begin{array}{c}\text { Pre- } \\
\text { sampling } \\
\text { pumping } \\
\text { time } \\
\text { (hours) }\end{array}$ & $\begin{array}{l}\text { Water } \\
\text { clear }\end{array}$ \\
\hline \multirow[t]{2}{*}{ NOTS $1 \mathrm{~A}$} & \multirow[t]{2}{*}{$16 \mathrm{~N}-02 \mathrm{~W}-21$ BAA 3} & 176.0 & Air lift & - & 1.5 & Sub. elec. & 6 & 4 & $\mathrm{~N}$ \\
\hline & & 229.0 & Air lift & - & 2 & Sub. elec. & 6 & 2 & $\mathrm{~N}$ \\
\hline NOTS 2 & $15 \mathrm{~N}-03 \mathrm{E}-31 \mathrm{BAA} 2$ & 106.4 & Air lift & 0.25 & 7 & Bladder & 0.3 & 4 & $\mathrm{~N}$ \\
\hline \multirow[t]{3}{*}{ NOTS 3} & \multirow[t]{3}{*}{$14 \mathrm{~N}-02 \mathrm{~W}-23 \mathrm{CCA} 1$} & 119.5 & Air lift & 2.5 & 4.5 & Sub. elec. & 7.5 & 3 & $\mathrm{Y}$ \\
\hline & & 119.5 & Air lift & 2.5 & 4.5 & Sub. elec. & 7.5 & 3 & $\mathrm{Y}$ \\
\hline & & 164.9 & Air lift & 0.5 & 5 & Sub. elec. & 3 & 1 & M \\
\hline \multirow[t]{4}{*}{ NOTS 4} & \multirow[t]{4}{*}{$10 \mathrm{~N}-01 \mathrm{E}-11 \mathrm{BBB} 1$} & 101.0 & Air lift & 4 & 3 & Sub. elec. & 7.5 & 3 & $\mathrm{Y}$ \\
\hline & & 156.2 & Air lift & 15 & 3 & Sub. elec. & 10 & 2 & $\mathrm{Y}$ \\
\hline & & 189.0 & Air lift & 3 & 3 & Sub. elec. & 3 & 2 & $\mathrm{Y}$ \\
\hline & & 257.5 & Air lift & - & 4 & Sub. elec. & 10 & 3 & $\mathrm{Y}$ \\
\hline \multirow[t]{4}{*}{ NOTS 5} & \multirow[t]{4}{*}{$08 \mathrm{~N}-03 \mathrm{E}-03 \mathrm{DAA} 1$} & 62.0 & Air lift & 3.5 & 1.5 & Sub. elec. & 10 & 1 & $\mathrm{Y}$ \\
\hline & & 62.0 & Air lift & 3.5 & 1.5 & Sub. elec. & 10 & 1 & $\mathrm{Y}$ \\
\hline & & 131.0 & Air lift & 0.5 & 3 & Sub. elec. & 1 & 1 & M \\
\hline & & 183.5 & Air lift & - & 3 & Sub. elec. & 6 & 2 & $\mathrm{Y}$ \\
\hline \multirow[t]{9}{*}{ NOTS 6} & \multirow[t]{9}{*}{$14 \mathrm{~N}-03 \mathrm{~W}-07$ DAA 2} & 106.2 & Air lift & 2 & 1 & Sub. elec. & 3 & 1 & $\mathrm{Y}$ \\
\hline & & 141.0 & Air lift & 7 & 2.5 & Sub. elec. & 7 & 3 & $\mathrm{Y}$ \\
\hline & & 180.8 & Air lift & 17 & 3 & Sub. elec. & 10 & 2 & $\mathrm{Y}$ \\
\hline & & 180.8 & Air lift & 17 & 3 & Sub. elec. & 10 & 2 & $\mathrm{Y}$ \\
\hline & & 222.8 & Air lift & 30 & 2 & Sub. elec. & 9 & 1 & $\mathrm{Y}$ \\
\hline & & 276.2 & Air lift & 2.5 & 3.5 & Sub. elec. & 6 & 2 & $\mathrm{Y}$ \\
\hline & & 296.2 & Air lift & 3 & 4 & Sub. elec. & - & 2 & $\mathrm{Y}$ \\
\hline & & 327.1 & Air lift & 7 & 3 & Sub. elec. & 7 & 3 & M \\
\hline & & 475.1 & Air lift & 15 & 3 & Sub. elec. & 5.5 & 6 & $\mathrm{~N}$ \\
\hline NOTS 7 & $09 \mathrm{~N}-02 \mathrm{~W}-29$ DCA 5 & 262.7 & Sub. elec. & 0.5 & 5 & Sub. elec. & - & - & $\mathrm{N}$ \\
\hline \multirow[t]{5}{*}{ NOTS $7 \mathrm{~A}$} & \multirow[t]{5}{*}{$09 \mathrm{~N}-02 \mathrm{~W}-29$ DCA 6} & 330.1 & Bladder, & 0.2 & 24 & Pump jack & 2.5 & 1.5 & $\mathrm{~N}$ \\
\hline & & & then pump jack & 1.7 & 5 & & & & \\
\hline & & 407.5 & Pump jack & 2.5 & 10 & Bladder & 一 & - & $\mathrm{N}$ \\
\hline & & 480.0 & Pump jack & 2.5 & 32 & Bladder & .25 & 8 & $\mathrm{~N}$ \\
\hline & & 480.0 & Pump jack & 2.5 & 32 & Bladder & .25 & 8 & $\mathrm{~N}$ \\
\hline
\end{tabular}


Table 5.-Field procedures for collection and preservation of water samples for laboratory analysis

[Dissolved, concentration in filtered sample; total, total recoverable concentration including suspended and colloidal solids; ${ }^{\circ} \mathrm{C}$, degrees Celsius; DCP, direct coupled plasma]

\begin{tabular}{|c|c|c|c|}
\hline Constituents to be analysed & Filter type(s) used & $\begin{array}{c}\text { Collection } \\
\text { bottle type }\end{array}$ & Preservation method \\
\hline $\begin{array}{l}\text { Major cations and trace elements, } \\
\text { dissolved except those listed below }\end{array}$ & $\begin{array}{l}0.45 \text {-micrometer cartridge prefilter } \\
\text { with } 0.2 \text {-micrometer membrane filter }\end{array}$ & $\begin{array}{l}\text { Acid-rinsed } \\
\text { polyethylene }\end{array}$ & Nitric acid to $\mathrm{pH} 2$ or less \\
\hline $\begin{array}{l}\text { Major anions, dissolved, } \mathrm{pH} \text {, and } \\
\text { specific conductance }\end{array}$ & $\begin{array}{l}0.45 \text {-micrometer cartridge prefilter } \\
\text { with } 0.2 \text {-micrometer membrane filter }\end{array}$ & $\begin{array}{l}\text { Non-acid-rinsed } \\
\text { polyethylene }\end{array}$ & None \\
\hline Nutrients & $\begin{array}{l}0.45 \text {-micrometer cartridge prefilter } \\
\text { with } 0.2 \text {-micrometer membrane filter }\end{array}$ & $\begin{array}{l}\text { Amber } \\
\text { polyethylene }\end{array}$ & $\begin{array}{l}\text { Mercuric chloride-sodium chloride ampoule, chill } \\
\text { to } 4{ }^{\circ} \mathrm{C}\end{array}$ \\
\hline $\begin{array}{l}\text { Trace elements, total, including } \\
\text { uranium }\end{array}$ & $\begin{array}{l}\text { Unfiltered, sieved through } 325 \text { mesh } \\
\text { plastic screen to remove sand }\end{array}$ & $\begin{array}{l}\text { Acid-rinsed } \\
\text { polyethylene }\end{array}$ & Nitric acid to $\mathrm{pH} 2$ or less \\
\hline $\begin{array}{l}\text { Arsenic and selenium species, } \\
\text { dissolved }\end{array}$ & $\begin{array}{l}0.45 \text {-micrometer cartridge prefilter } \\
\text { with } 0.2 \text {-micrometer membrane filter }\end{array}$ & $\begin{array}{l}\text { Acid-rinsed } \\
\text { polyethylene }\end{array}$ & $\begin{array}{l}\text { Ultrapure hydrochloric acid to } \mathrm{pH} 1 \text {, keep dark, } \\
\text { chill to } 4{ }^{\circ} \mathrm{C}\end{array}$ \\
\hline $\begin{array}{l}\text { Chromium, dissolved for analysis } \\
\text { by DCP }\end{array}$ & $\begin{array}{l}0.45 \text {-micrometer cartridge prefilter } \\
\text { with } 0.2 \text {-micrometer membrane filter }\end{array}$ & Acid-rinsed teflon & Ultrapure nitric acid to $\mathrm{pH} 2$ or less, keep dark \\
\hline Chromium, hexavalent, dissolved & $\begin{array}{l}0.45 \text {-micrometer cartridge prefilter } \\
\text { with } 0.2 \text {-micrometer membrane filter }\end{array}$ & $\begin{array}{l}\text { Acid-rinsed } \\
\text { polyethylene }\end{array}$ & Nitric acid to $\mathrm{pH} 3$, keep dark, chill to $4^{\circ} \mathrm{C}$ \\
\hline Mercury, dissolved & $\begin{array}{l}0.45 \text {-micrometer cartridge prefilter } \\
\text { with } 0.2 \text {-micrometer membrane filter }\end{array}$ & Baked glass & Nitric acid/potassium dichromate ampoule \\
\hline Organic carbon, dissolved & 0.45-micrometer silver filter & Baked glass & $\begin{array}{l}\text { Mercuric chloride-sodium chloride ampoule, chill } \\
\text { to } 4^{\circ} \mathrm{C}\end{array}$ \\
\hline $\begin{array}{l}\text { Carbon-13/carbon- } 12 \\
\text { isotope ratio }\end{array}$ & $\begin{array}{l}0.45 \text {-micrometer cartridge prefilter } \\
\text { with } 0.2 \text {-micrometer membrane filter }\end{array}$ & Glass & $\begin{array}{l}\text { Ammoniacal strontium chloride, mercuric chlo- } \\
\text { ride tablet }\end{array}$ \\
\hline $\begin{array}{l}\text { Gross-alpha and -beta activity, } \\
\text { suspended and dissolved }\end{array}$ & $\begin{array}{l}\text { Unfiltered, sieved through } 325 \text { mesh } \\
\text { plastic screen to remove sand }\end{array}$ & $\begin{array}{l}\text { Acid-rinsed } \\
\text { polyethylene }\end{array}$ & None \\
\hline Radium and uranium isotopes & $\begin{array}{l}0.45 \text {-micrometer cartridge prefilter } \\
\text { with } 0.2 \text {-micrometer membrane filter }\end{array}$ & $\begin{array}{l}\text { Acid-rinsed } \\
\text { polyethylene }\end{array}$ & Hydrochloric acid to $\mathrm{pH} 2$ or less \\
\hline Radon, total & $\begin{array}{l}\text { Unfiltered, sampled under pressure } \\
\text { with plastic syringe }\end{array}$ & Scintillation vial & Express under scintillation cocktail, shake \\
\hline $\begin{array}{l}\text { Stable hydrogen and oxygen iso- } \\
\text { tope ratios }\end{array}$ & $\begin{array}{l}\text { Unfiltered, sieved through } 325 \text { mesh plas- } \\
\text { tic screen to remove sand }\end{array}$ & Glass & Mercuric chloride tablet \\
\hline Stable sulfur isotope ratio & $\begin{array}{l}\text { Unfiltered, sieved through } 325 \text { mesh plas- } \\
\text { tic screen to remove sand }\end{array}$ & $\begin{array}{l}\text { Acid-rinsed } \\
\text { polyethylene }\end{array}$ & Mercuric chloride tablet \\
\hline Tritium & $\begin{array}{l}\text { Unfiltered, sieved through } 325 \text { mesh plas- } \\
\text { tic screen to remove sand }\end{array}$ & Glass & None \\
\hline
\end{tabular}


California. All other samples for arsenic species were analyzed by Battelle Pacific Northwest Division $^{1}$, Marine Sciences Laboratory, Sequim, Washington.

Determinations of arsenic species concentrations made by the Branch of Regional Research were made using flow-through hydride-generation atomic-absorption spectrophotometry. Arsenite was analyzed from an aliquot of the sample buffered to $\mathrm{pH} 5$ using a buffer composed of 1.78-molar sodium acetate and 1-molar acetic acid. The aliquot was then reacted with a solution of 1-percent sodium borohydride to generate an arsenic hydride. The hydride was carried by nitrogen carrier gas to the absorption cell placed in the flame of the spectrophotometer. Total arsenic concentration was measured from a sample aliquot that was reduced with a solution of potassium iodide in 40-percent hydrochloric acid. A solution of 10-Normal hydrochloric acid was added in place of the buffer used for arsenite. Total arsenic in the aliquot was analyzed by generating arsenic hydride in the same manner as that used for arsenite. Arsenate was calculated to be the difference between total arsenic and arsenite (Tallman and Shaikh, 1980).

Battelle used a similar method for the analysis of arsenic species using hydride-generation atomic-adsorption spectrophotometry as described by Andreae (1977). In that method, as in the Branch of Regional Research method, arsenite and total arsenic concentrations are analyzed and arsenate concentration is determined by the difference between the two.

Selenium species were determined by the California District Office of the U.S. Geological Survey, Water Resources Division, Sacramento, California. The methods used are described in Fio and Fujii (1988).

Carbon-14 was determined by the Radiocarbon Laboratory at the Institute for the Study of Earth and Man, Southern Methodist University, Dallas, Texas. The sample was hydrolyzed with 80 percent hydrochloric acid and the carbon in the resulting gas was frozen in a cold trap using liquid nitrogen. The frozen carbon was transferred to a benzene synthesis system and was converted to benzene. The carbon-14 content of the benzene was measured to determine the percent modern carbon (personal communication, Herbert Haas).

Stable isotopes were analysed using mass spectrometry after the element was converted to a gas or included in a gaseous compound. Carbon-13 and carbon- 12 were determined from $\mathrm{CO}_{2}$ gas generated by reacting the strontium carbonate precipitate with 100 percent orthophosphoric acid. The amount of $\mathrm{CO}_{2}$ gas produced was measured monometrically. The carbon-13-carbon-12 ratio was then normalized to a $\delta$-value in permil relative to the PDB (Peedee Belemnite) standard (Crey, 1950). Deuterium and hydrogen were measured after conversion to $\mathrm{H}_{2}$ gas by reduction with zinc metal. The deuterium-hydrogen isotope ratio was then normalized to a $\delta$-value in permil relative to the VSMOW-SLAP (Vienna Standard Mean Ocean Water-Standard Light Antartic Precipitation) scale such that SLAP has a value of -428 permil (Kendall and Coplen, 1985). Oxygen-18 and oxygen-16 were determined from $\mathrm{CO}_{2}$ gas which was equilibrated with the water sample. The oxygen isotope ratio was normalized to a $\delta$-value relative to the VSMOW-SLAP scale such that SLAP has a value of -55.5 permil (Epstein and Mayeda, 1953). The normalized values for oxygen and hydrogen isotopes are related back to the original Standard Mean Ocean Water

\footnotetext{
${ }^{1}$ Use of trade names in this report is for identification purposes only and does not constitute endorsement by the U.S. Geological Survey.
} 
Water (SMOW) through SLAP by the VSMOW-SLAP scale and are reported as permil relative to SMOW. Sulfur-34 and sulfur-32 were measured in $\mathrm{SO}_{2}$ gas that was generated by precipitating $\mathrm{BaSO}_{4}$ from the sample by adding $\mathrm{BaCl}_{2}$ and then roasting that precipitate mixed with $\mathrm{Cu}_{2} \mathrm{O}$ and $\mathrm{SiO}_{2}$ at $1,125^{\circ}$ Celsius. The $\mathrm{SO}_{2}$ gas was purified using a vacuum distillation line. The sulfur isotope ratio was normalized to a $\delta$-value relative to CDT (Canyon Diablo Troilite) using the McMaster University reference standards (Rees, 1978, Woodruff and Shanks, 1988).

\section{Analytical Results}

Analytical results, for all parameters except carbon-14, are summarized in tables 7 through 13. Results listed as having no data available were either lost in transit to the analyzing laboratory, were not collected due to difficulty filtering the samples, or a decision was made not to have that determination done on all samples.

Determinations listed as "dissolved" in the column header were measured from a filtered sample. Determinations listed as "total" or "whole" were measured from an unfiltered sample that had passed through a 325-mesh plastic screen. Thus, concentrations listed for total or whole determinations include contributions to the concentration of the element from suspended clays or colloidal material in the sample. Determinations listed as "suspended" were measured from the material retained on a 0.45 -micrometer membrane filter after filtering a sample that had previously been passed through a 325 -mesh plastic screen.

Carbon-14 determination for a sample collected from test-hole NOTS 7A at a sampling depth of $329.1 \mathrm{ft}$ gave a calculated percent modern carbon of $20.556 \pm 0.485$.

\section{GEOPHYSICAL LOGS}

\section{Methods}

For the NOTS project the Geological Survey ran a suite of logs which included: Mechanical caliper log; neutron, gamma-gamma, and natural-gamma nuclear logs; spontaneouspotential, long- and short-normal-resistivity, and single-point-resistance electric logs. A brief description of each log classified by log type follows. These descriptions are adapted from Keys and McCrary (1971).

\section{Mechanical $\log$}

Caliper. - The caliper log is a record of the average diameter of a drill hole. This $\log$ provides information about the borehole size and stability. 
Neutron. - A neutron $\log$ is a record of the signal from a neutron source to a detector arranged in a probe such that the signal is primarily a function of the hydrogen content of the borehole environment. Neutron logs are useful for the measurement of the moisture content of formations above the water table, and of total porosity of the formation below the water table.

Gamma-gamma. - Gamma-gamma logs are records of the intensity of gamma radiation that is back-scattered by the rocks in the surrounding borehole environment. Gamma radiation is emitted from a source in the probe and the amount of radiation returning to the probe is measured. The intensity of the back-scattered radiation, with the appropriate corrections, is inversely proportional to the bulk density of the formation adjacent to the borehole. The gamma-gamma log is sensitive to borehole variations and is useful in finding washouts as well as determining bulk densities.

Natural gamma. - Natural-gamma logs are records of the amount of natural-gamma radiation that is emitted by rocks. All rocks emit gamma radiation. Certain types of rocks such as shale tend to emit more gamma rays than other types of rocks. Natural-gamma logs are generally good shale indicators and are useful in determining the lithologies intercepted by the borehole.

\section{Electric logs}

Spontaneous potential. - Spontaneous-potential logs are records of the potentials or voltages that develop naturally at the contacts between a bed of shale or clay and a bed of sand where penetrated by a borehole. Spontaneous potential is strongly affected by the salinities of the borehole fluid and the formation water. The direction of the spontaneous potential response to changes in lithology depends on which fluid, borehole or formation, is more saline. This factor is important to interpretation and application of spontaneous potential logs to ground-water studies. Spontaneous potential logs are useful for determining lithology and bed thickness.

Normal resistivity. - Normal-resistivity logs measure the apparent resistivity of a volume of rock surrounding the electrodes. The short-normal (16-inch spacing between electrodes) records the apparent resistivity of the zone invaded by the drilling fluids very near the well bore and gives good vertical detail of changes in lithology. The long-normal (64-inch spacing between electrodes) records the apparent resistivity beyond the zone invaded by the drilling fluid and is more indicative of the true formation resistivity.

Single-point resistance. - Single-point resistance logs measure the resistance of the earth materials lying between an in-hole electrode and a surface electrode, or between two in-hole 
electrodes. The NOTS project utilized in-hole and surface electrodes to measure single-point resistance. Single-point-resistance logs cannot be used quantitatively, but are excellent for providing lithologic information.

On test-holes NOTS 1 through NOTS 5 all logs were obtained using a single conductor EG\&G Mount Sopris Instruments ${ }^{2}$ model II portable borehole logger. The individual tools were run one at a time and their responses were recorded from the bottom to the top of the borehole.

Test-hole NOTS 6 was logged in two stages because of hole degradation. The entire array of logs could not be run before the hole collapsed. The bottom parts of the neutron, gamma-gamma, spontaneous-potential, and single-point-resistivity logs were obtained after the upper part of the hole was reamed to a larger diameter, cased with 6-inch steel casing, and the bottom of the hole restored.

Test-holes NOTS 7 and 7A were cored, logged, reamed, and cased in sections to help preserve the integrity of the holes. The suite of logs run in test-hole NOTS 7 did not include long- and short-normal logs because the normal resistivity tool did not function. Geophysical logs of NOTS 7A were gathered using a modified multi-conductor Well-Reconnaissance logger. Due to technical difficulties with the Well-Reconnaissance logger only the naturalgamma logs were usable.

\footnotetext{
${ }^{2}$ Use of brand names in this report is for identification purposes only and does not constitute endorsement by the U.S. Geological Survey.
} 


\section{Description of Log Presentation}

Figures 5-13 show the recorded logs for test-holes NOTS 1 through NOTS 7A. The log presentations are graphical plots of the digitized geophysical logs. The quality of the logs depends on the condition of the borehole, and the condition and availability of the logging equipment.

Long- and short-normal resistivity logs are presented as one plot. The 64 -inch longnormal resistivity is represented by a dashed line and the 16 -inch short-normal resistivity by a solid line. Open-hole water levels, sampled intervals, and geologic units are represented by symbols. Open-hole water levels were determined before any development of the test holes and are not necessarily representative of the static water levels. Numeric scales were omitted from the log presentation because the logging tools were not calibrated.

On test-holes NOTS 6 and 7 the gaps in the logs are intervals that were cased to stabilize the upper portion of the test hole. The upper part of the natural-gamma log of NOTS 7A between 200 feet and 570 feet depth was run through steel casing that extended from land surface to 475 feet. 

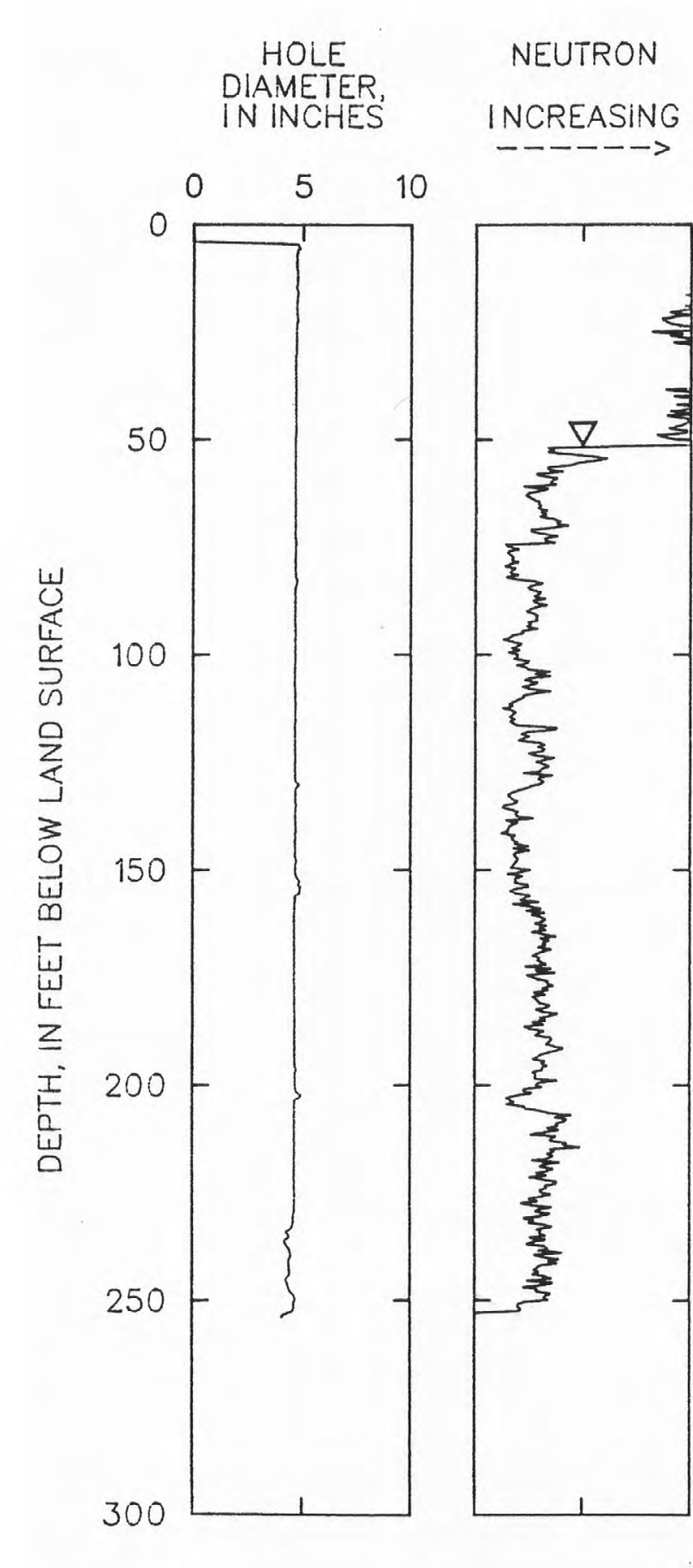

GAMMA-GAMMA
INCREASING

NATURAL-

SPONTANEOUS

NORMAL

SINGLE POINT

NCREASING POTENTIAL

INCREASING

INCREASING
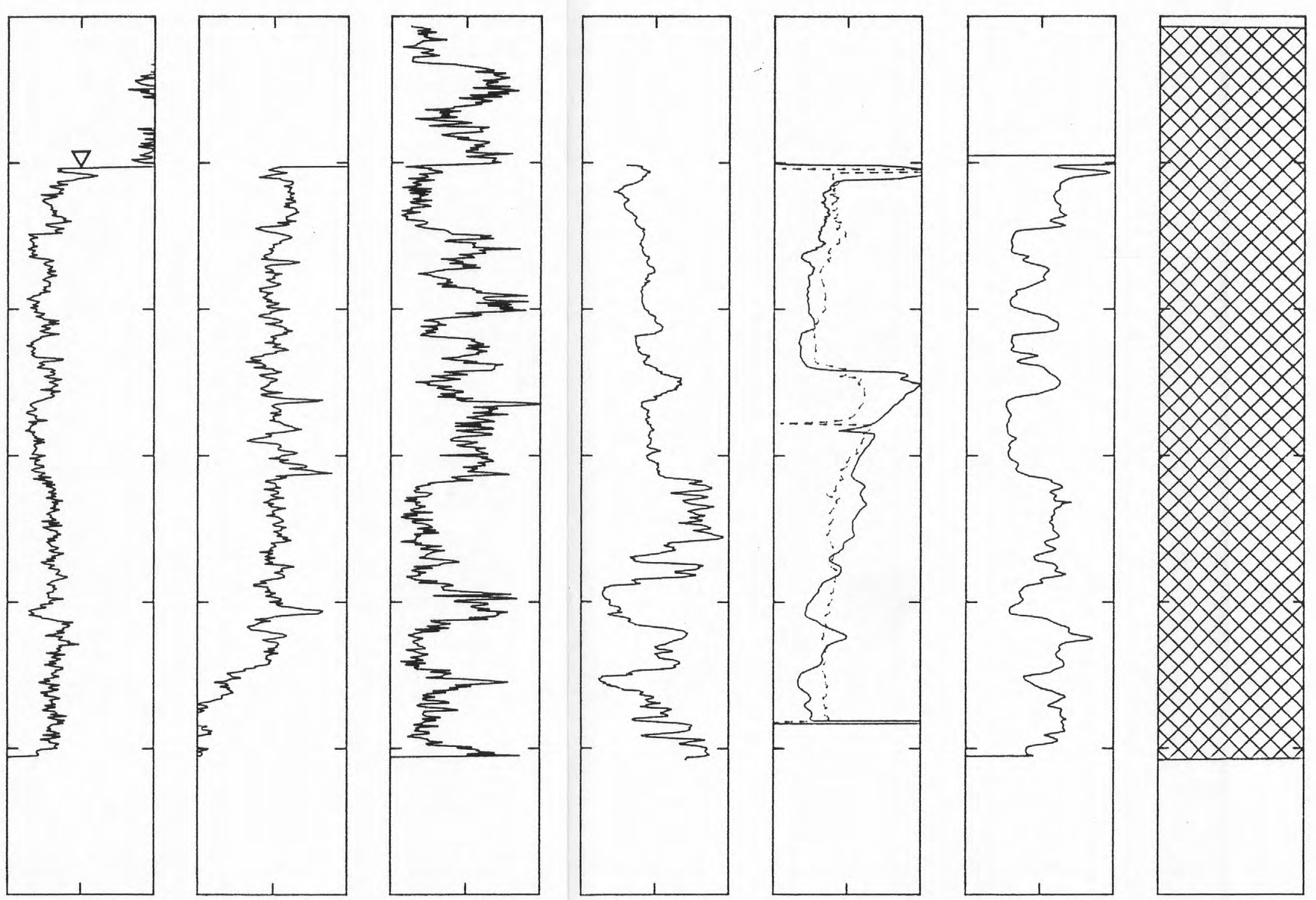

EXPLANATION

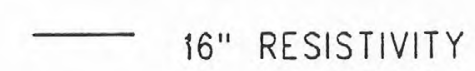

64" RESISTIVITY

$\nabla$ OPEN-HOLE WATER LEVEL

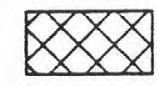

gaRBER sandstone

Figure 5.-Geophysical logs for test-hole NOTS 1. 

HOLE
DIAMETER

IN INCHES

$\begin{array}{lll}0 & 5 & 10\end{array}$

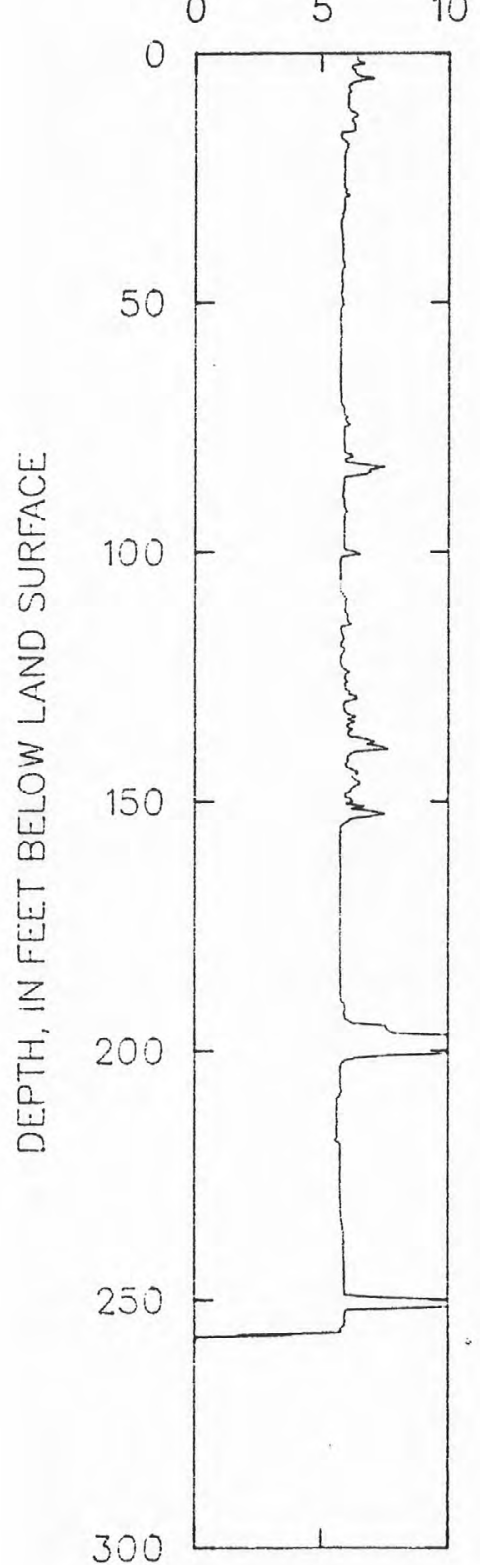

GAMMA-GAMMA

INCREASING

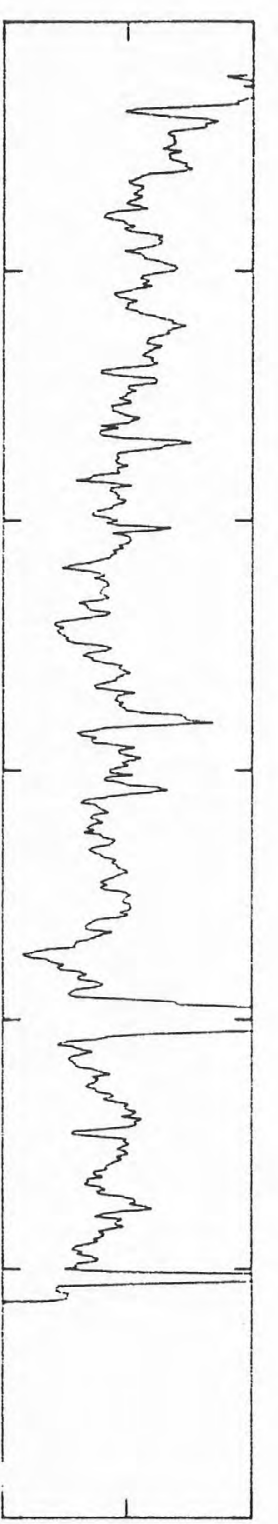

NATURAL-

INCREASING

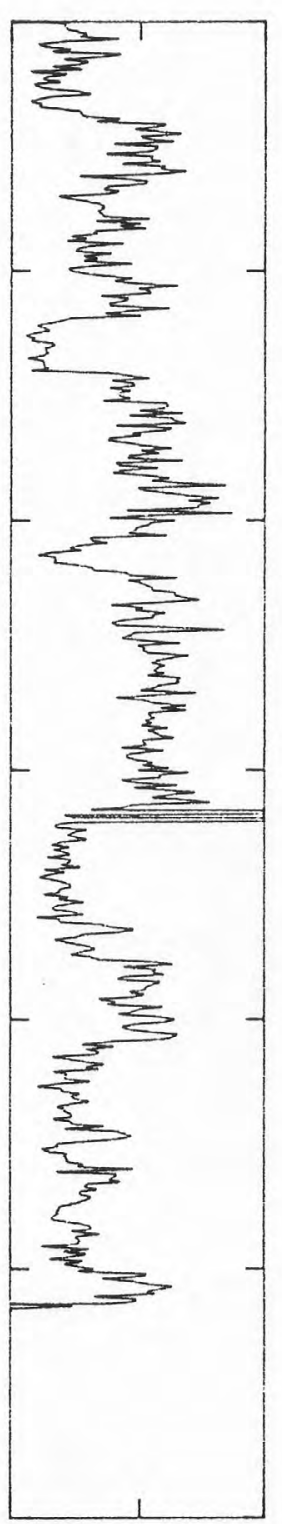

SPONTANEOUS POTENTIAL
NORMAL

INCREASING
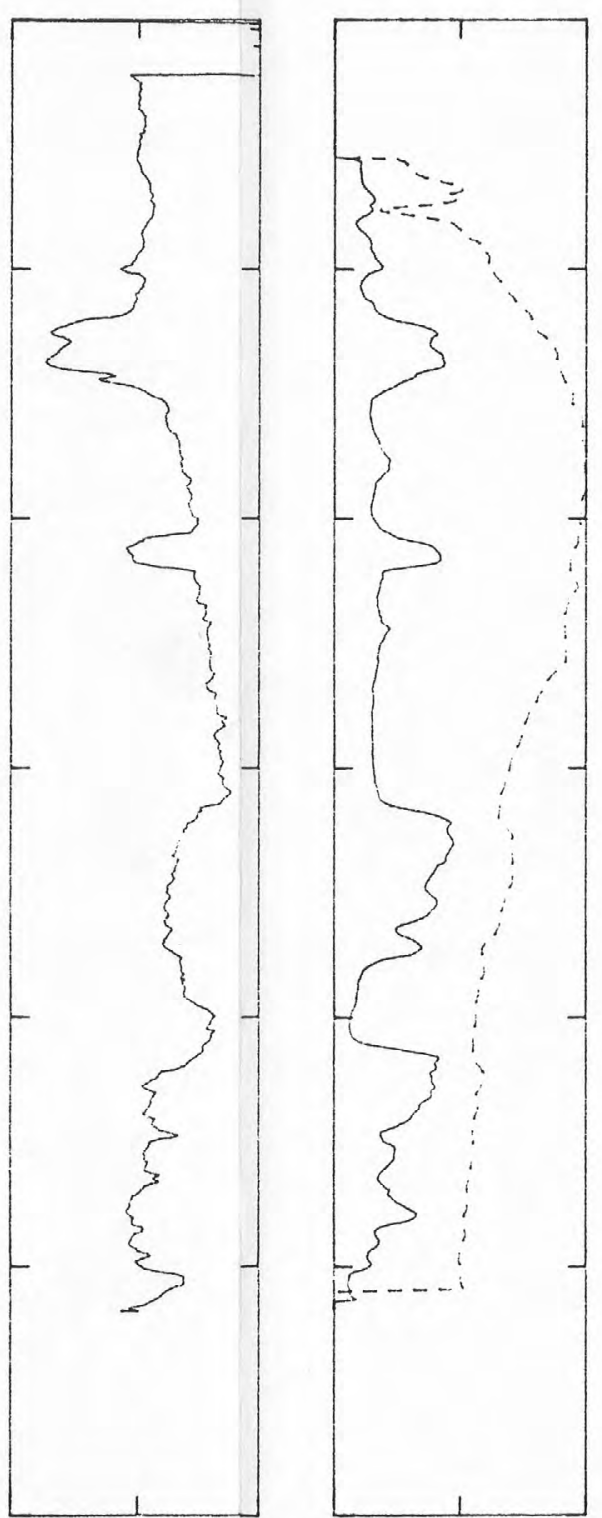
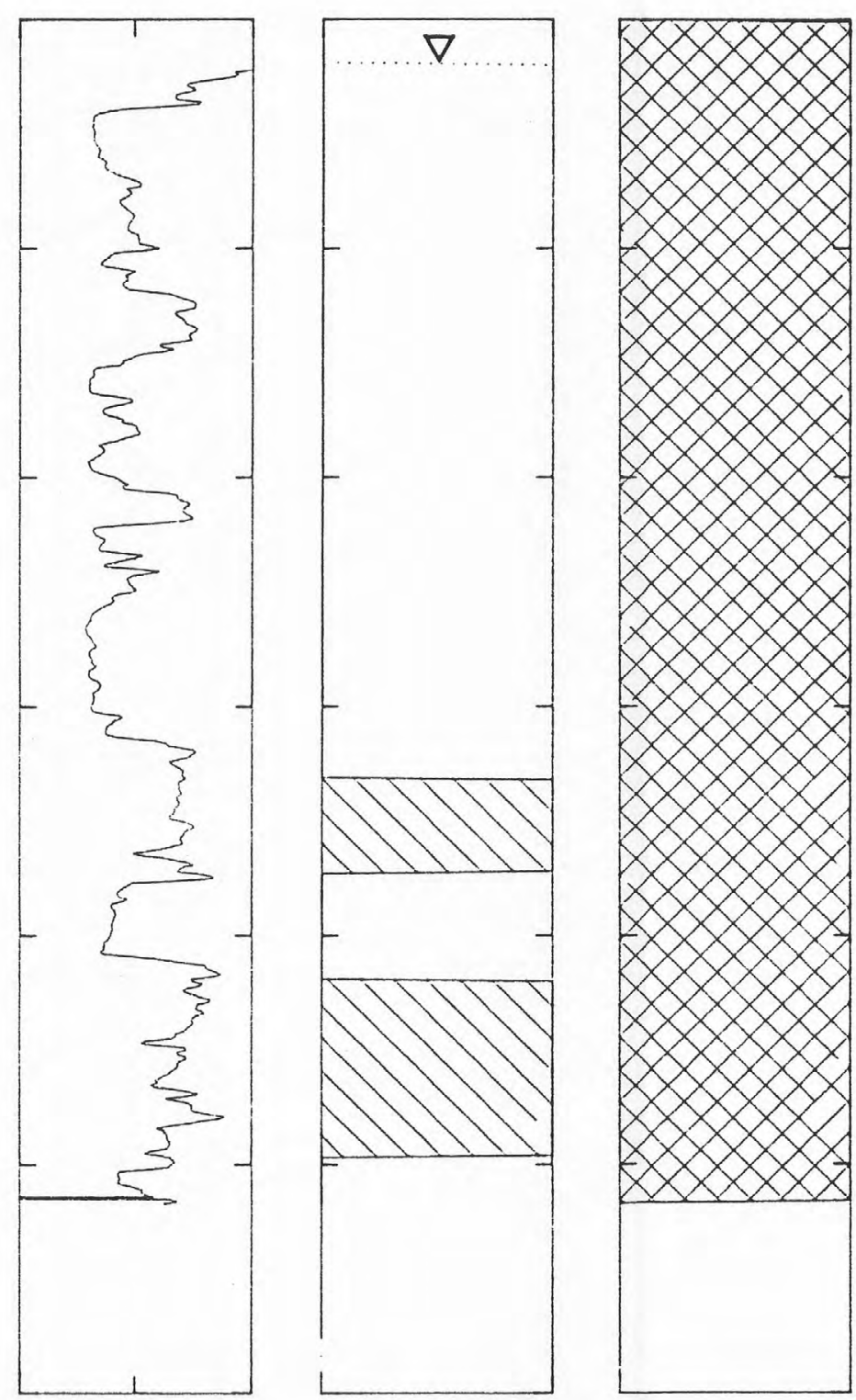

\section{EXPLANATION}

16" RESISTIVITY

64" RESISTIVITY

$\nabla$ OPEN-HOLE WATER LEVEL

MIN INTERVALS SAMPLED

\& Garber sandstone 

HOLE
DIAMETE

IN INCHES

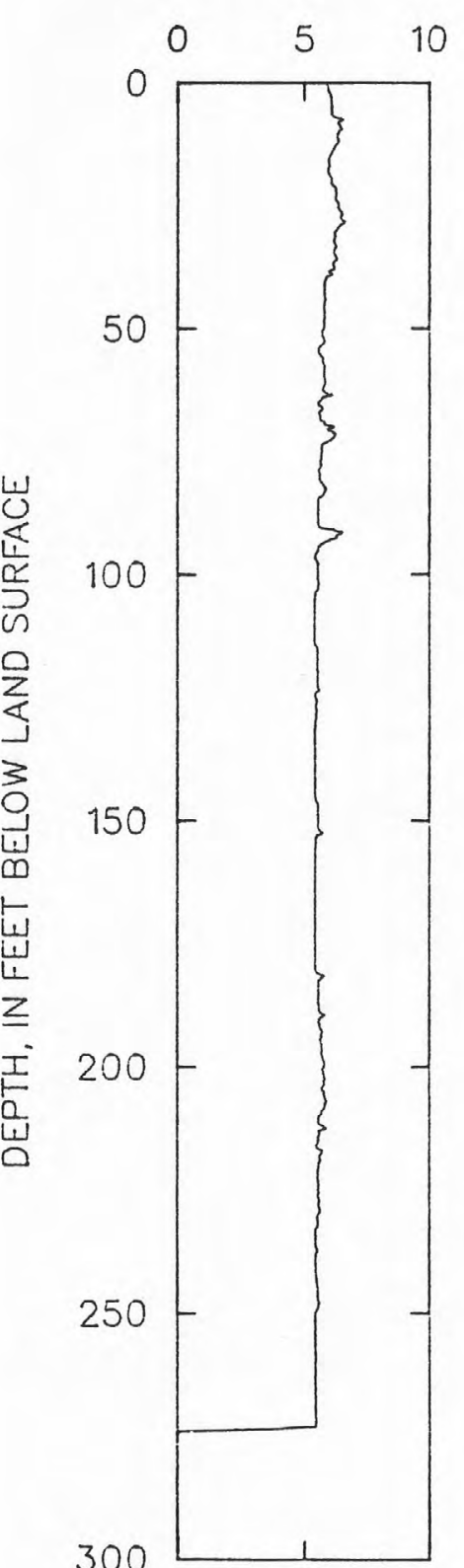

NEUTRON GAMMA-GAMMA

INCREASING

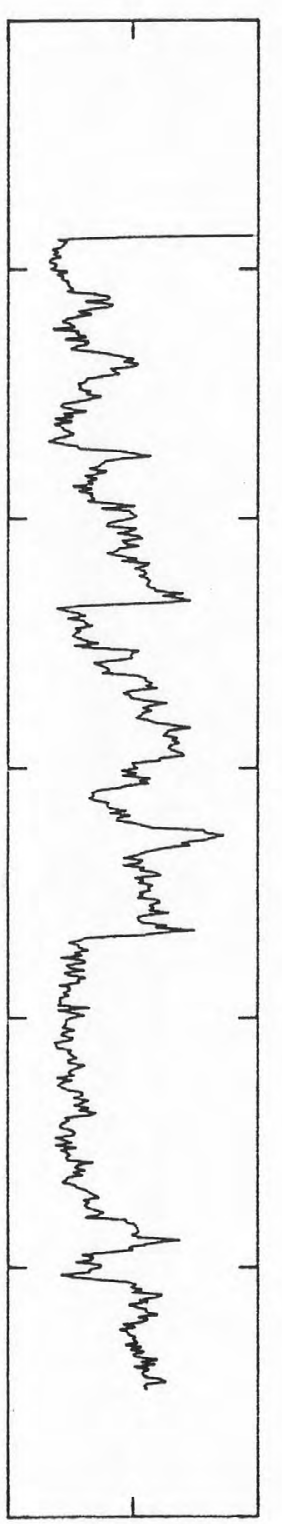

INCREASING

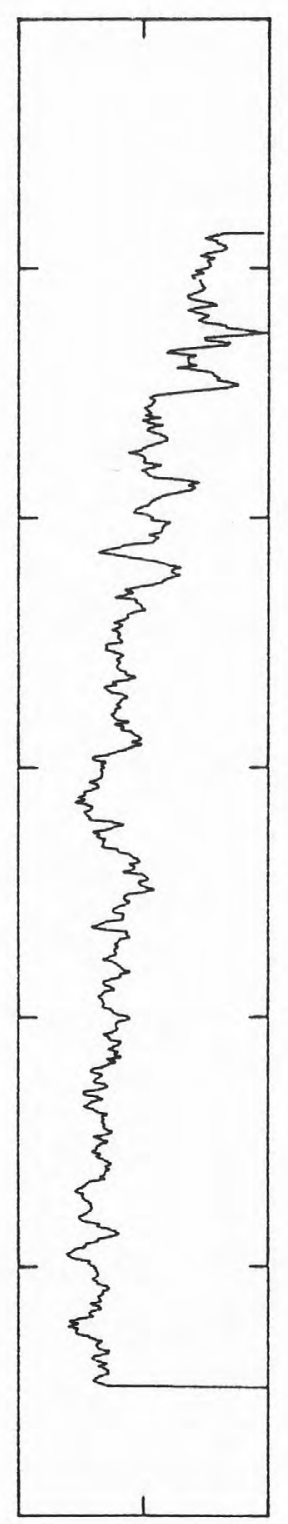

NATURAL-
GAMMA

INCREASING

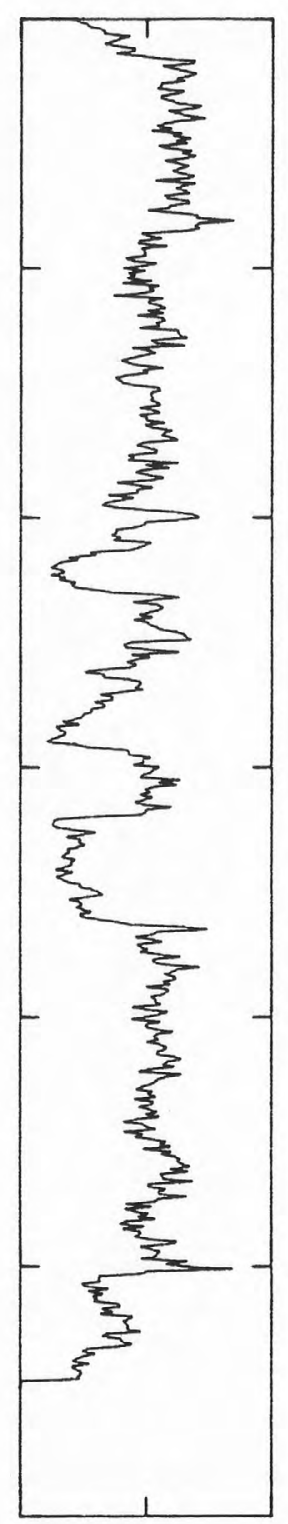

NORMAL

INCREASING

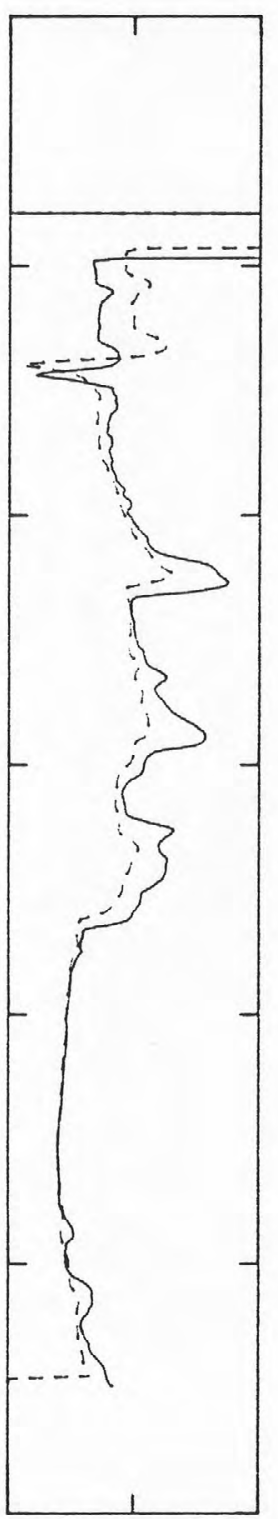

WATER -

SAMPLE

GEOLOGIC

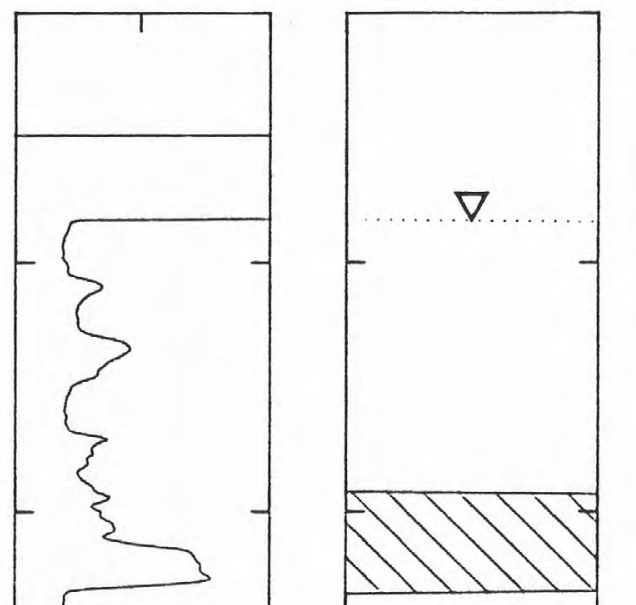

\#曲

+ -

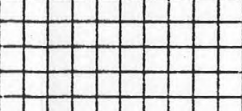

\begin{tabular}{|l|l|} 
\\
\hline
\end{tabular}

7

\begin{tabular}{|l|l|}
\hline & \\
\hline
\end{tabular}

\begin{tabular}{|l|l|}
\hline 1 & \\
\hline
\end{tabular}

$\because$

$1+11+$

$+$

$+$

$++1+$

$+(+1-10$

$+1$

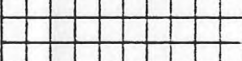

$+\quad+-1$

$+$

$+$

$\because+$

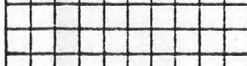

$+$

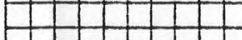

$+1$

\section{XPLANATION}

16" RESISTIVITY

64" RESISTIVITY

$\nabla$ OPEN-HOLE WATER LEVEL INTERVAL SAMPLED

CHASE, COUNCIL GROVE

AND ADMIRE
UNDIVIDED 

HOLE
DIAMETER
ININCHES

NEUTRON

INCREASING
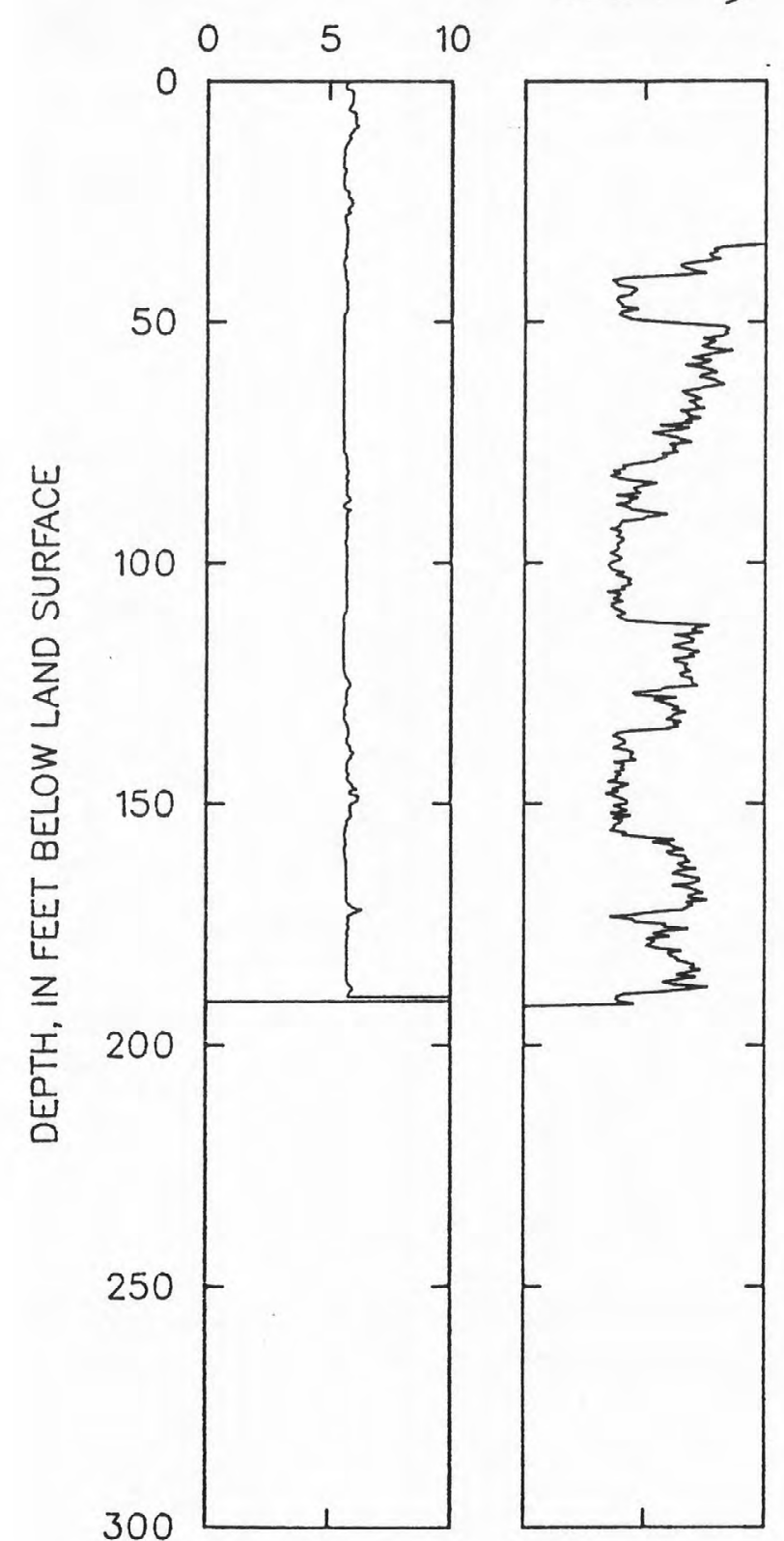

INCREASING

NATURAL-

NCREASING

NCREASING
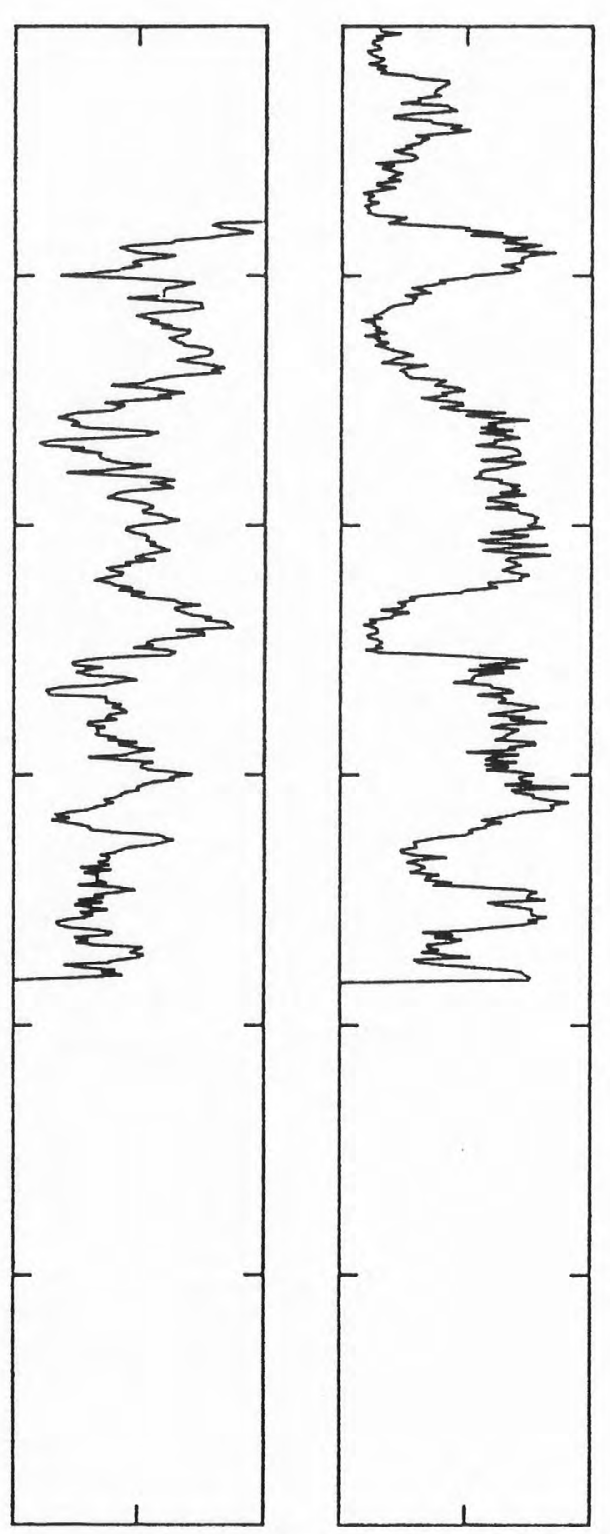
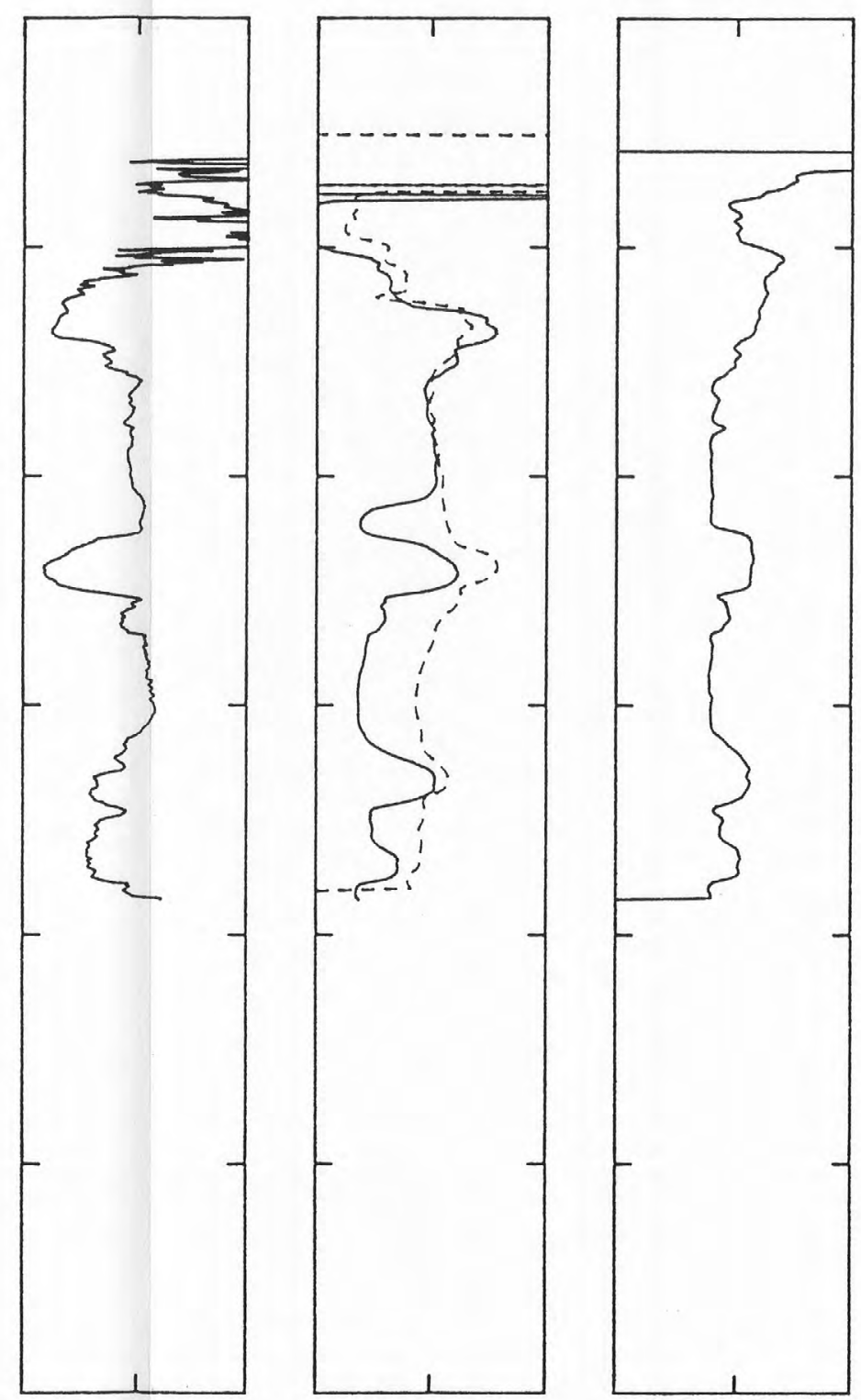

WATER-

SAMPLE

GEOLOGIC

RESISTIVITY

INCREASING

EXPLANATION

16" RESISTIVITY

64" RESISTIVITY

$\nabla$ OPEN-HOLE WATER LEVEL

DI

NTERVALS SAMPLED

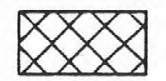

GARBER SANDSTONE 

HOLE

NEUTRON

GAMMA-GAMMA

INCREASING

POTENTIAL

NCREASING
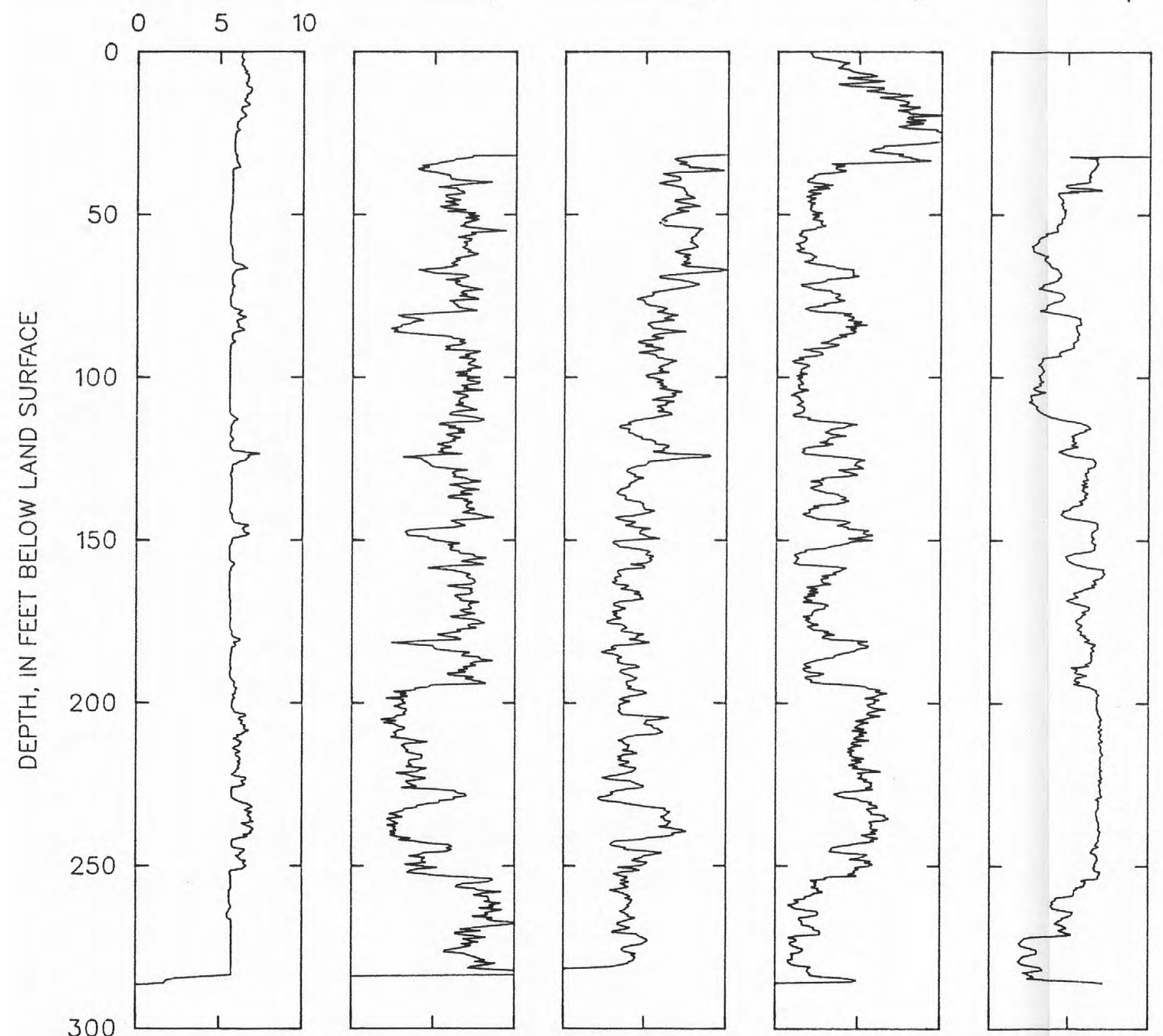
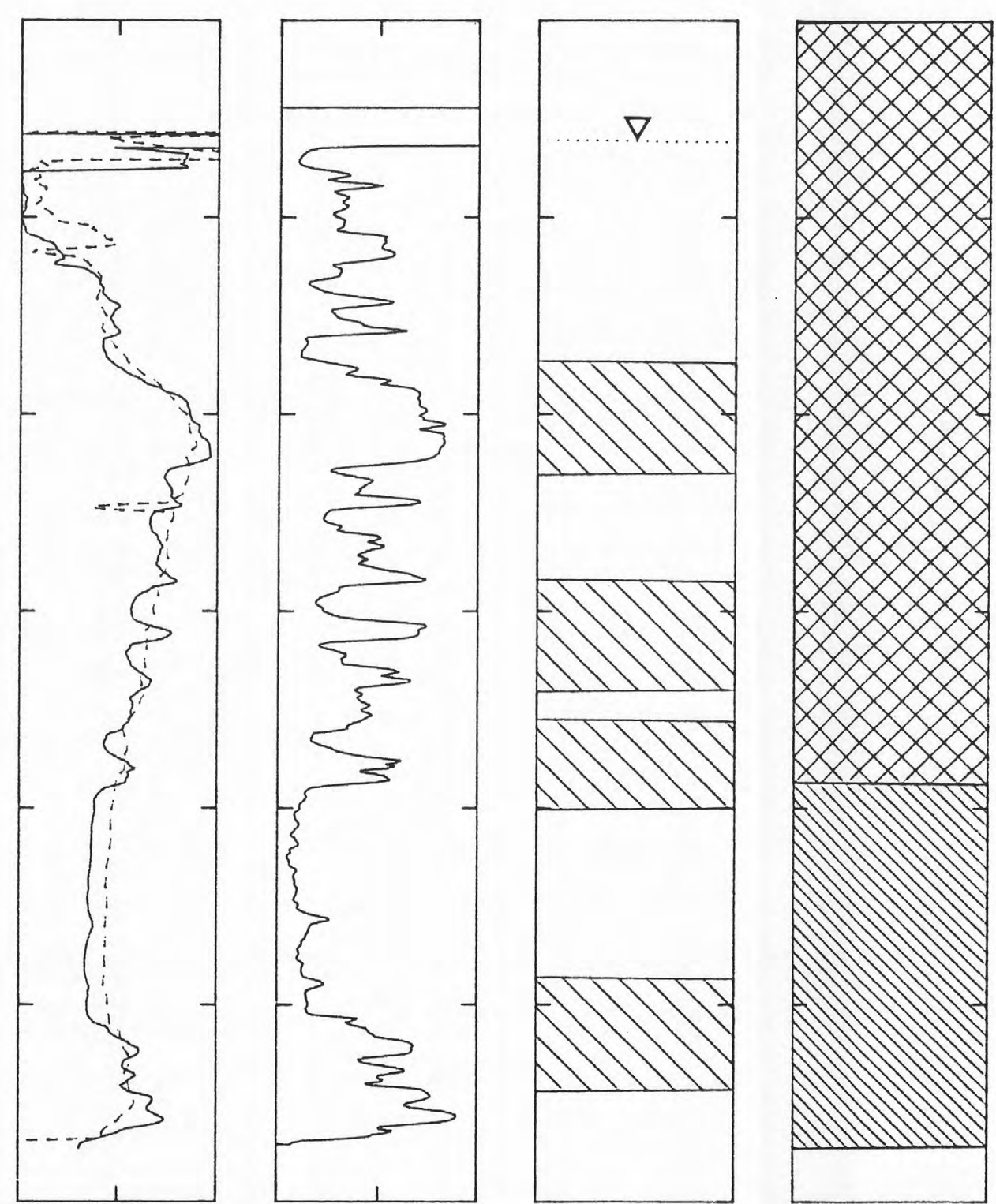

\section{EXPLANATION}

6" RESISTIVITY

6" RESISTIVITY

$\nabla$ OPEN-HOLE WATER LEVEL

MINTERVALS SAMPLED

$叉$ GaRbER SANDSTONE

MII WELLINGTON FORMATION 

HOLE

NEUTRON

INCREASING

INCREASING

SPONTANEOUS

POTENTIAL

INCREASING
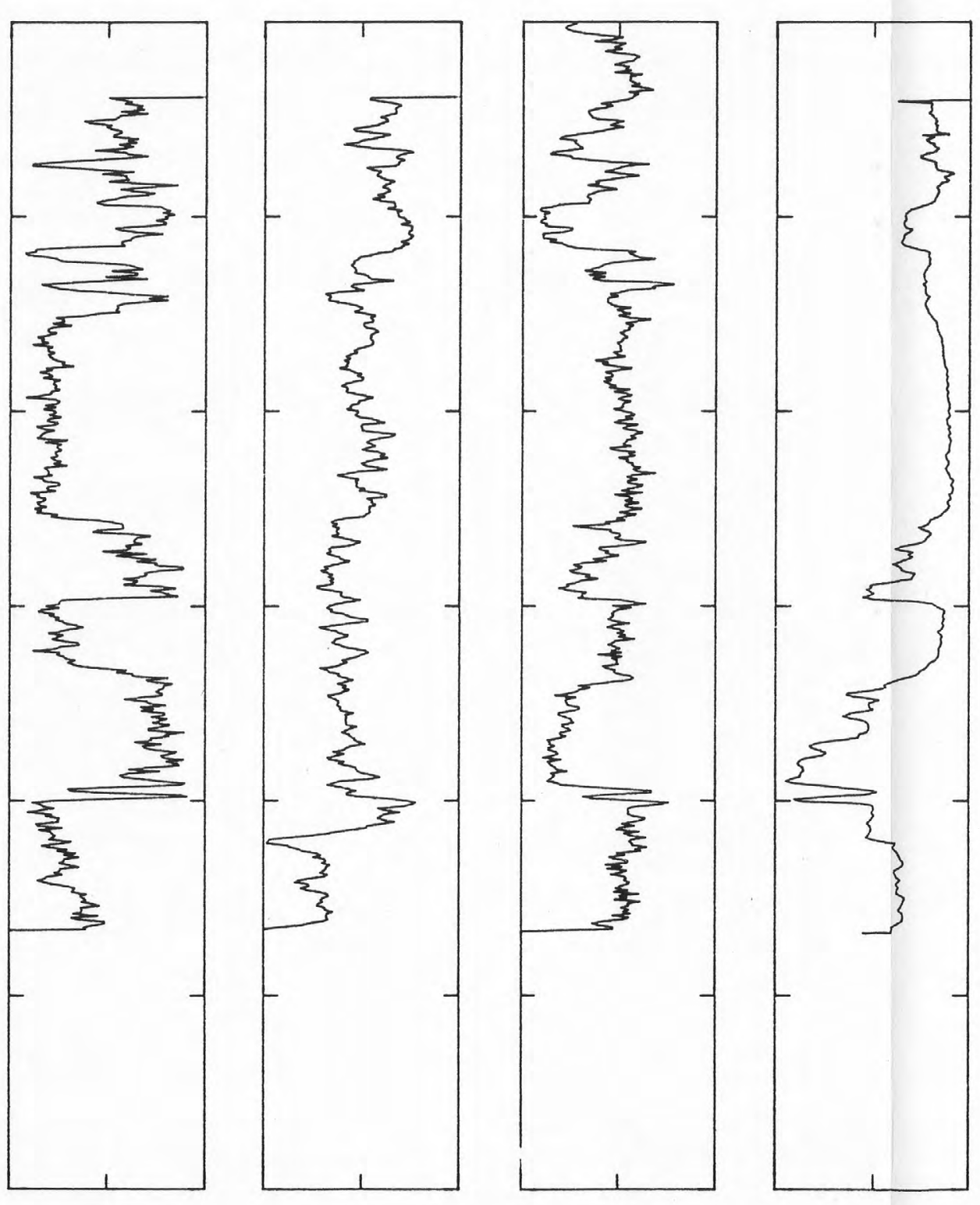
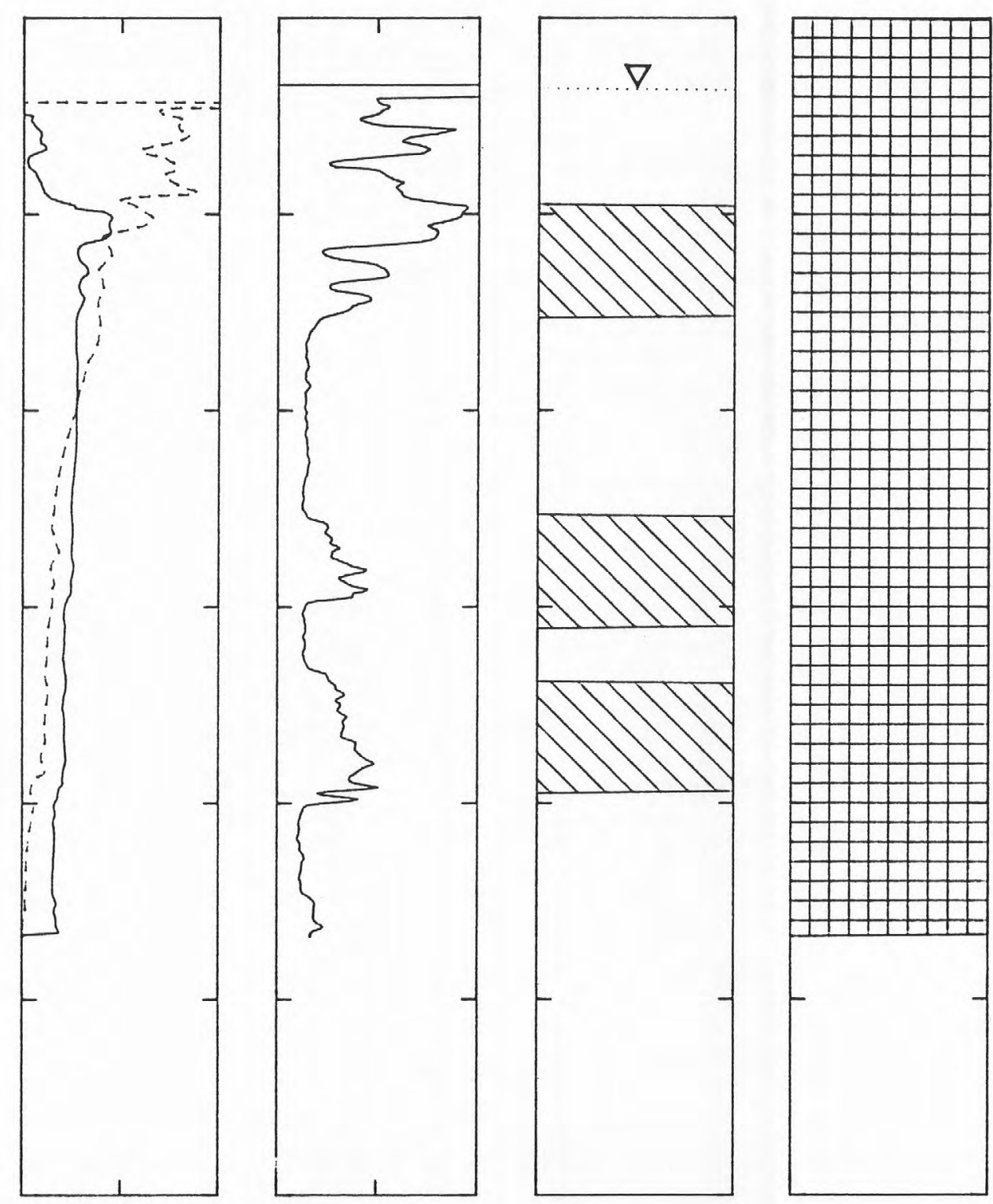

EXPLANATION

$\longrightarrow$

6" RESISTIVITY

64" RESISTIVITY

$\nabla$ OPEN-HOLE WATER LEVEL

MIN INTERVALS SAMPLED

CHASE, COUNCIL GROVE,

AND ADMIRE GROUPS,
UNDIVIDED 



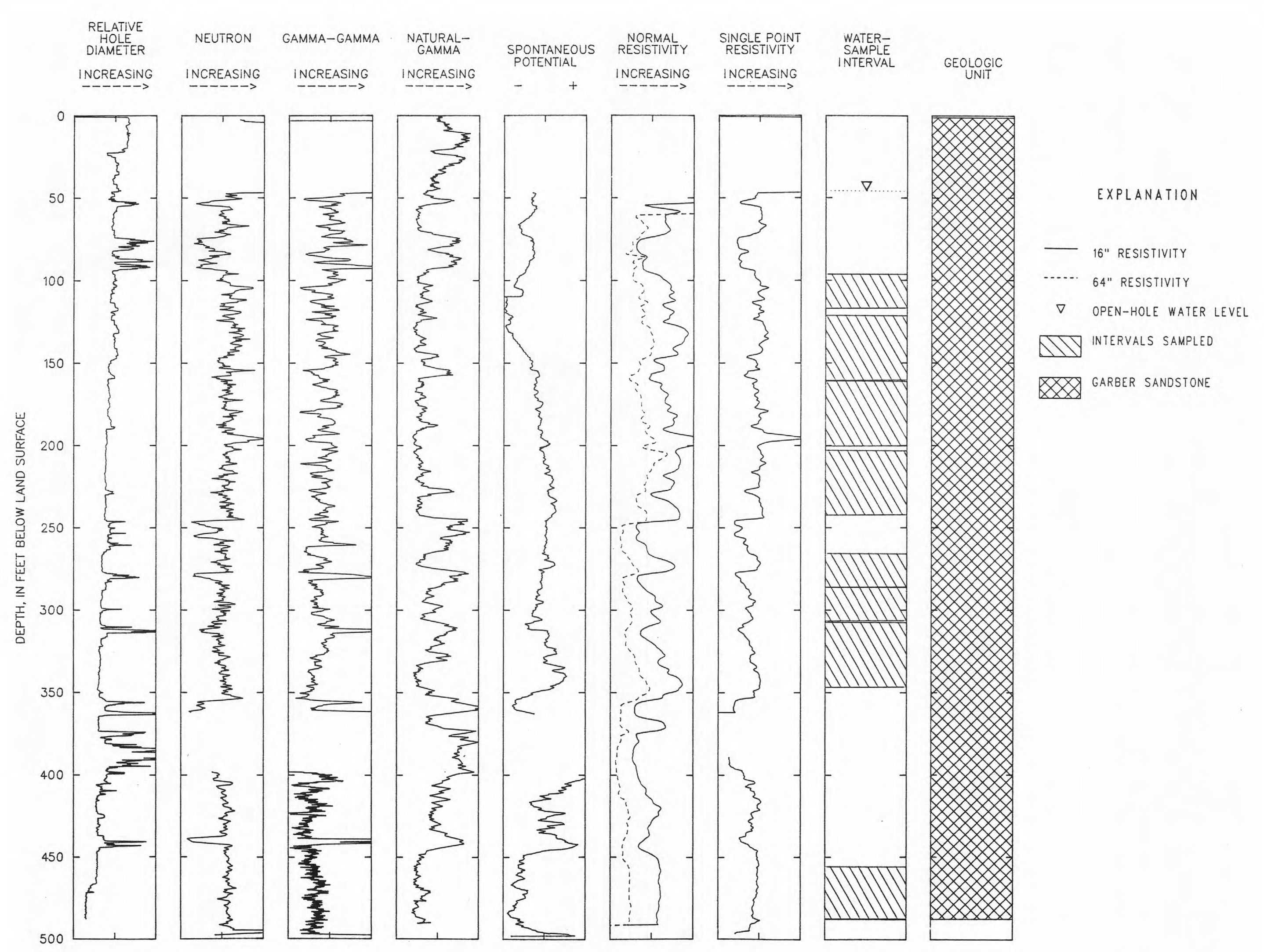

Figure 11.-Geophysical logs for test-hole NOTS 6. 



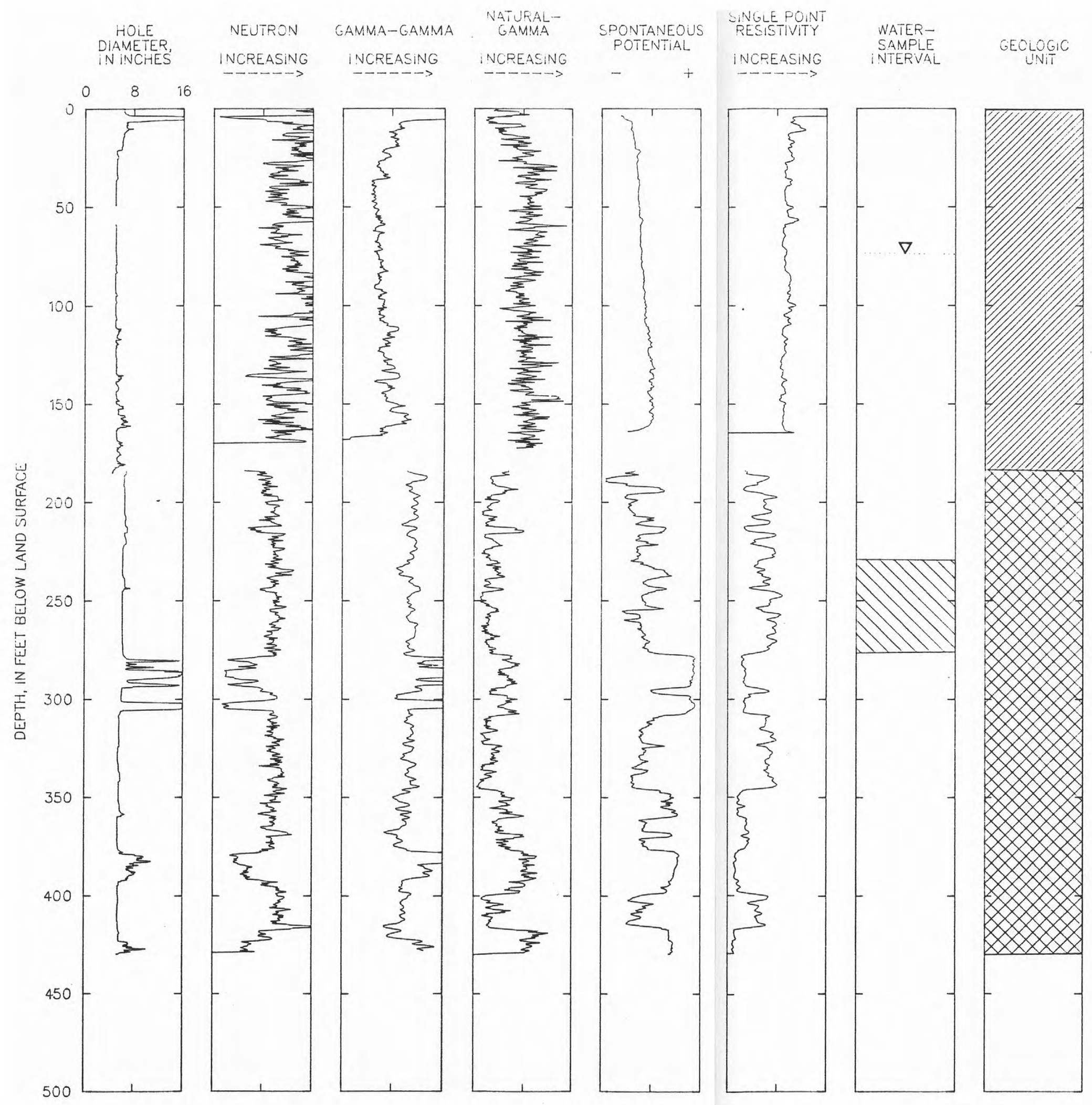

EXPLANATION

$\nabla$ OPEN-HOLE WATER LEVEL MIN INTERVAL SAMPLED

ZIII HENNESSEY GROUP

X Garber sandstone

Figure 12.-Geophysical logs for test-hole NOTS 7. 



$\begin{array}{cccc}\text { NATURAL- } & \text { NATURAL- } & & \\ \text { GAMMA } & \text { GAMMA } & \text { WATER- } & \\ \text { INCREASING } & \text { INAMPLE } & \text { GEOLOGIC } \\ & \text { INCREASING } & \text { INTERVAL } & \text { UNIT }\end{array}$

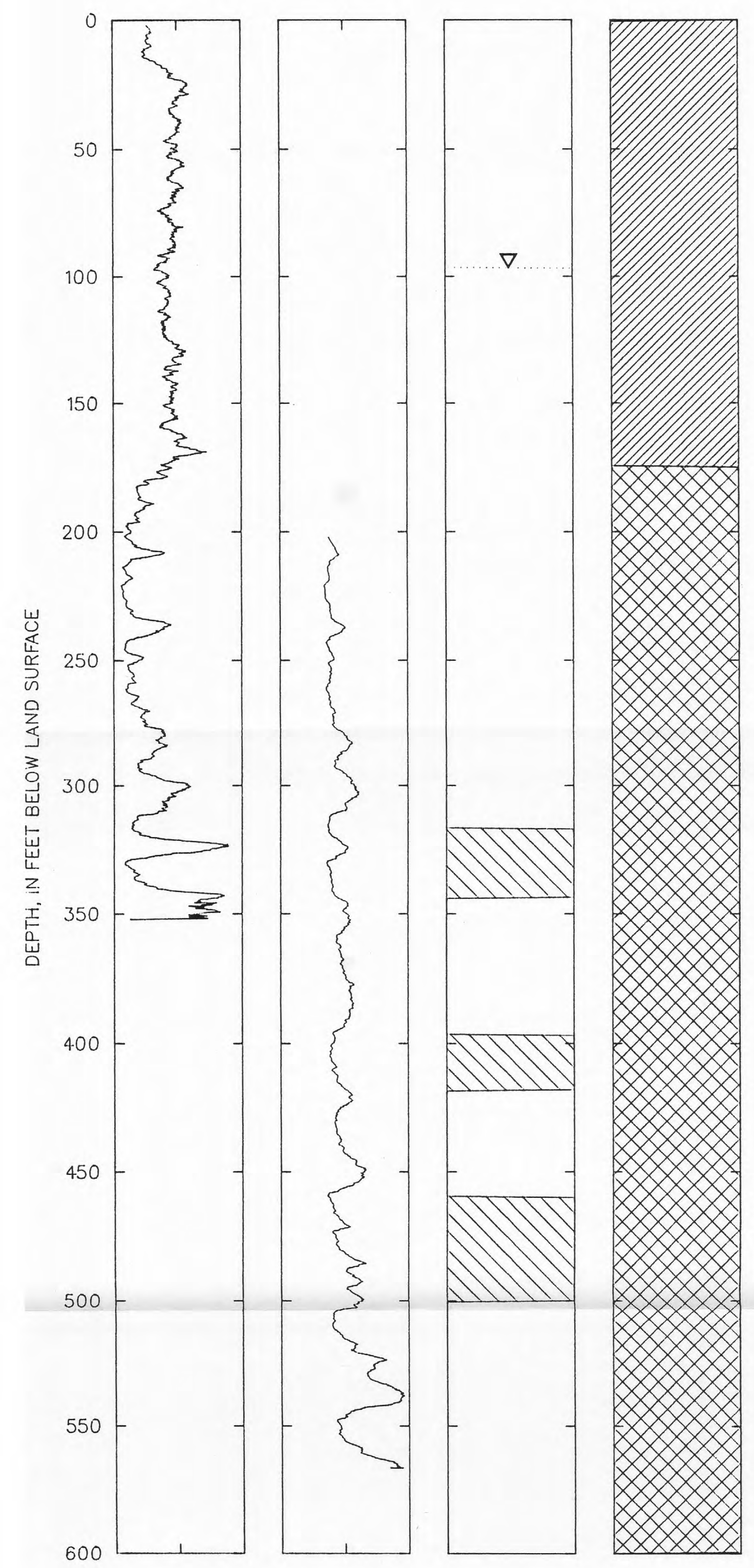

EXPLANATION

$\nabla$ OPEN-HOLE WATER LEVEL

INTERVALS SAMPLED

ZDIT HENNESSEY GROUP

叉 Garber sandstone

Figure 13.-Geophysical logs for test-hole NOTS 7A. 



\section{REFERENCES CITED}

Andreae, M.O., 1977, Determination of arsenic species in natural waters: Analytical Chemistry, v. 49 , p. $820-828$.

Bingham, R.H., and Moore, R.L., 1975, Reconnaissance of the water resources of the Oklahoma City quadrangle, central Oklahoma: Oklahoma Geological Survey Hydrologic Atlas 4, scale 1:250,000, 4 sheets.

Breit, G.N., Rice, C., Esposito, K., and Schlottmann, J.L., 1990, Mineralogy and petrography of Permian rocks in the Central Oklahoma aquifer: U.S. Geological Survey Open-File Report 90-678, 50 p.

Brown, Eugene, Skougstad, M.W., and Fishman, M.J., 1970, Methods for collection and analysis of water samples for dissolved minerals and gases: U.S. Geological Survey Techniques of Water-Resources Investigations, Book 5, Chapter A1, 160 p.

Crey, J.M., 1950, On the isotope chemistry of carbonates and a paleotemperature scale: Joural of Chemical Physics, v. 18, p 849-857.

Epstein, S. and Mayeda, T., 1953, Variation of ${ }^{18} \mathrm{O}$ content of waters from natural sources: Geochimica et Cosmochimica Acta, v. 4, p 213-224.

Fio, J.L., and Fujii, R., 1988, Comparison of methods to determine selenium species in saturation extracts of soils from the western San Joaquin Valley, California: U.S. Geological Survey Open-File Report 88-458, 16 p.

Fishman, M.J., and Friedman, L.C., editors, 1989, Methods for the determination of inorganic substances in water and fluvial sediments: U.S. Geological Survey Techniques of Water-Resources Investigations, Book 5, Chapter A1, 545 p.

Hart, D.L., Jr., 1974, Reconnaissance of the water resources of the Ardmore and Sherman quadrangles, southern Oklahoma: Oklahoma Geological Survey Hydrologic Atlas 3, scale $1: 250,000,2$ sheets.

Hirsch, R. M., Alley, W.M., and Wilber, W.G., 1988, Concepts for a National Water-Quality assessment Program: U.S. Geological Survey Circular 1021, 42 p.

Kendall, C. and Coplen, T.B., 1985, Multisample conversion of water to hydrogen by zinc for stable isotope geochemistry: Analytical Chemistry, v. 57, p. 1,437-1,440.

Keys, W.S., and MacCary, L.M., 1971, Application of borehole geophysics to water-resources investigations: U.S. Geological Survey Techniques of Water-Resources Investigations, Book 2, Chapter E1, 126 p.

Knapton, J.R., 1985, Field guidelines for collection, treatment, and analysis of water samples, Montana District: U.S. Geological Survey Open-File Report 85-409, 86 p.

Mosier, E.L., Briggs, P.H., Crock, J.G., Kennedy, K.R., McKown, D.M., Vaugn, R.B., and Welsh, E.P., 1990, Analyses of subsurface Permian rock samples from the Central Oklahoma aquifer: U.S. Geological Survey Open-File Report 90-456, 68 p. 
Parkhurst, D.L., Christenson, S.C. and Schlottmann, J.L., 1989, Ground-water Quality Assessment of the Central Oklahoma Aquifer, Oklahoma-analysis of available waterquality data through 1987: U.S. Geological Survey Open-File Report 88-728, 80 p.

Rees, C.E., 1978, Sulphur isotope measurements using $\mathrm{SO}_{2}$ and $\mathrm{SF}_{6}$ : Geochemica et Cosmochimica Acta, v. 42, p. 383-389.

Tallman, D.E. and Shaikh, A.U., 1980, Redox stability of inorganic arsenic (III) and arsenic (V) in aqueous solution: Analytical Chemistry, v. 52, no. 1, p. 196-199.

Thatcher, L.L., Janzer, V.J., and Edwards, K.W., 1977, Methods of determination of radioactive substances in water and fluvial substances: U.S. Geological Survey Techniques of Water-Resources Investigations, Book 5, Chapter A5, 95 p.

U.S. Environmental Protection Agency, 1986, Maximum contaminant levels (subpart B of part 141, National interim primary drinking-water regulations): U.S. Code of Federal Regulations, Title 40, Parts 100-149, revised as of July 1, 1986, p. 374.

Woodruff, L.G. and Shanks, W.C., III, 1988, Sulfur isotope study of chimney minerals and vent fluids from $21^{\circ} \mathrm{N}$, East Pacific Rise: Hydrothermal sulfur sources and disequilibrium sulfate reduction: Journal of Geophysical Research, v. 93, no. B5, p. 4,562-4,572. 
Table 6. - Listing of analytical methods used at the National Water Quality Laboratory

[Parameter code; codes used to designate chemical constituents in the WATSTORE data base of the U.S. Geological Survey and in

the STORET data base of the Environmental Protection Agency; $\mathrm{g} / \mathrm{ml}$, grams per milliliter; cm, centimeter; mg/L, milligrams per

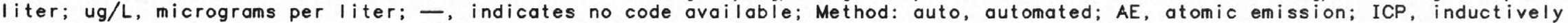
coupled plasma; AA, atomic absorption; DCP, directly coupled plasma; method number and laboratory code, codes used by the National Water Quality Laboratory of the U.S. Geological Survey to specify analytical methods; dissolved, concentration in filtered sample; total, total recoverable concentration including suspended and colloidal solids; pCi/L, picocuries per liter; PDB, Peedee Belemnite; SMOW, Standard Mean Ocean Water; CDT, Canyon Diablo Troilite]

\begin{tabular}{|c|c|c|c|c|c|}
\hline $\begin{array}{l}\text { Para- } \\
\text { meter } \\
\text { code }\end{array}$ & $\begin{array}{l}\text { Parameter name } \\
\text { phase and units }\end{array}$ & Method & $\begin{array}{l}\text { Method } \\
\text { number }\end{array}$ & $\begin{array}{l}\text { Laboratory } \\
\text { code }\end{array}$ & $\begin{array}{l}\text { Detection } \\
\text { limit }\end{array}$ \\
\hline \multicolumn{6}{|c|}{ WATER PROPERTIES } \\
\hline 71820 & $\begin{array}{l}\text { Density, } \\
\text { dissolved } \mathrm{g} / \mathrm{ml} \text { at } 20 \text { degrees Celcius }\end{array}$ & Gravimetry & $1312-85$ & LCOO24 & 0.99 \\
\hline 00403 & $\mathrm{pH}$ laboratory (standard units) & Electrometry, glass electrode, auto & $2587-85$ & $\mathrm{SH} 1043$ & 4.0 \\
\hline 90095 & $\begin{array}{l}\text { Specific conductance, laboratory } \\
\text { microsiemens } / \mathrm{cm} \text { at } 25 \text { degrees celcius }\end{array}$ & Electrometry, auto & $2781-85$ & $\mathrm{SH} 1043$ & 1 \\
\hline \multicolumn{6}{|c|}{ MAJOR CATIONS } \\
\hline 00915 & $\begin{array}{l}\text { Calcium, } \\
\text { dissolved ( } \mathrm{mg} / \mathrm{L} \text { as } \mathrm{Ca})\end{array}$ & AE ICP, direct & $1472-85$ & $\mathrm{SH} 1043$ & .02 \\
\hline 00925 & $\begin{array}{l}\text { Magnesium, } \\
\text { dissolved ( } \mathrm{mg} / \mathrm{L} \text { as } \mathrm{Mg})\end{array}$ & AE ICP, direct & $1472-85$ & $\mathrm{SH} 1043$ & .01 \\
\hline 00935 & $\begin{array}{l}\text { Potassium, } \\
\text { dissoived (mg/L as } K)\end{array}$ & AA, direct & $1630-85$ & LC0054 & .1 \\
\hline 00930 & $\begin{array}{l}\text { Sodium, } \\
\text { dissolved ( } \mathrm{mg} / \mathrm{L} \text { as } \mathrm{Na})\end{array}$ & AE ICP, direct & $1472-85$ & $\mathrm{SH} 1043$ & 1 \\
\hline \multicolumn{6}{|c|}{ MAJOR ANIONS } \\
\hline 71870 & $\begin{array}{l}\text { Bromide, } \\
\text { dissolved ( } \mathrm{mg} / \mathrm{L} \text { as } \mathrm{Br})\end{array}$ & Colorimetry, fluorescein, auto & $2129-85$ & LC1246 & .01 \\
\hline 00940 & $\begin{array}{l}\text { Chloride, } \\
\quad \text { dissolved }(\mathrm{mg} / \mathrm{L} \text { as } \mathrm{Cl})\end{array}$ & Colorimetry, thiocyanate, auto & $2187-85$ & LCOO15 & .1 \\
\hline 00950 & $\begin{array}{l}\text { Fluoride, } \\
\text { dissolved ( } \mathrm{mg} / \mathrm{L} \text { as } \mathrm{F})\end{array}$ & Ion selective electrode, auto & $2327-85$ & LCo031 & .1 \\
\hline 71865 & $\begin{array}{l}\text { Iodide, } \\
\text { dissolved (mg/L as I) }\end{array}$ & Colorimetry, ceric-arsenious oxide, auto & $2371-85$ & LC1202 & .001 \\
\hline 00955 & $\begin{array}{l}\text { Silica, } \\
\text { dissolved }\left(\mathrm{mg} / \mathrm{L} \text { as } \mathrm{SiO}_{2}\right)\end{array}$ & AE ICP, direct & $1472-85$ & SH1043 & .01 \\
\hline 00945 & $\begin{array}{l}\text { Sulfate, } \\
\text { dissolved }\left(\mathrm{mg} / \mathrm{L} \text { as } \mathrm{SO}_{4}\right)\end{array}$ & Turbidimetry, auto, background corrected & - & LC1551 & 1 \\
\hline \multicolumn{6}{|c|}{ NUTRIENTS } \\
\hline 00608 & $\begin{array}{l}\text { Nitrogen, ammonia, } \\
\text { dissolved }(m g / L \text { as } N)\end{array}$ & Colorimetry, auto & $2522-85$ & LCO301 & .01 \\
\hline 00613 & $\begin{array}{l}\text { Nitrogen, nitrite, } \\
\text { dissolved, (mg/L as } N)\end{array}$ & Colorimetry, diazotization, auto & $2540-85$ & LCO160 & .01 \\
\hline
\end{tabular}


Table 6. - Listing of analytical methods used at the National Water Quality Laboratory-Continued

\begin{tabular}{|c|c|c|c|c|c|}
\hline $\begin{array}{l}\text { Para- } \\
\text { meter } \\
\text { code }\end{array}$ & $\begin{array}{l}\text { Parameter name } \\
\text { phase and units }\end{array}$ & Method & $\begin{array}{l}\text { Method } \\
\text { number }\end{array}$ & $\begin{array}{l}\text { Laboratory } \\
\text { code }\end{array}$ & $\begin{array}{l}\text { Detection } \\
\text { Iimit }\end{array}$ \\
\hline \multicolumn{6}{|c|}{ NUTRIENTS } \\
\hline 00631 & $\begin{array}{l}\text { Nitrogen, nitrite plus nitrate, } \\
\text { dissolved ( } \mathrm{mg} / \mathrm{L} \text { as } \mathrm{N})\end{array}$ & Colorimetry, Cd-reduction, auto & $2545-85$ & LCO228 & .1 \\
\hline 00671 & $\begin{array}{c}\text { Phosphorous, orthophosphate, } \\
\text { dissolved ( } \mathrm{mg} / \mathrm{L} \text { as } \mathrm{P} \text { ) }\end{array}$ & Colorimetry, phosphomolybdate, auto & $2601-86$ & LCO162 & .01 \\
\hline \multicolumn{6}{|c|}{ CARBON } \\
\hline 00681 & $\begin{array}{l}\text { Carbon, organic, } \\
\text { dissolved }(\mathrm{mg} / \mathrm{L} \text { as } C)\end{array}$ & & $0002-78$ & LCO113 & .1 \\
\hline \multicolumn{6}{|c|}{ TRACE ELEMENTS } \\
\hline 01106 & $\begin{array}{l}\text { Aluminum, } \\
\text { dissolved (ug/L os } A I)\end{array}$ & $A E, D C P$ & $1054-86$ & LC1284 & 10 \\
\hline 01105 & $\begin{array}{l}\text { Aluminum, } \\
\text { total (ug/L as } A I)\end{array}$ & $A E, D C P$ & $3054-86$ & LC1283 & 10 \\
\hline 01000 & $\begin{array}{l}\text { Arsenic, } \\
\text { dissolved (ug/L as As) }\end{array}$ & AA, hydride, auto & $2062-85$ & LCO112 & 1 \\
\hline 01002 & $\begin{array}{l}\text { Arsenic, } \\
\text { total (ug/L as As) }\end{array}$ & $A A$, hydride, auto & $4062-85$ & LCO118 & 1 \\
\hline 01005 & $\begin{array}{l}\text { Barium, } \\
\text { dissolved (ug/L as } B a)\end{array}$ & $A E, I C P$, direct & $1472-85$ & $\mathrm{SH} 1043$ & 2 \\
\hline 01010 & $\begin{array}{l}\text { Beryllium, } \\
\text { dissolved (ug/L as Be) }\end{array}$ & $A E$, ICP, direct & $1472-85$ & $\mathrm{SH} 1043$ & .5 \\
\hline 01020 & $\begin{array}{l}\text { Boron, } \\
\text { dissolved (ug/L as } B \text { ) }\end{array}$ & $A E, D C P$, direct & $1114-86$ & LC1183 & 10 \\
\hline 01025 & $\begin{array}{l}\text { Cadmium, } \\
\text { dissolved (ug/L as Cd) }\end{array}$ & $A E, I C P$, direct & $1472-85$ & $\mathrm{SH} 1043$ & 1 \\
\hline 01030 & $\begin{array}{l}\text { Chromium, } \\
\text { dissolved (ug/L as } C r)\end{array}$ & $A E, I C P$, di rect & $1472-85$ & $\mathrm{SH} 1043$ & 5 \\
\hline 01030 & $\begin{array}{l}\text { Chromium, } \\
\quad \text { dissolved (ug/L as } C r \text { ) }\end{array}$ & $A E, D C P$, direct & $1229-87$ & LCO727 & 1 \\
\hline 01032 & $\begin{array}{l}\text { Chromium, } \\
\text { hexavalent, dissolved } \\
\text { (ug/L as } C r \text { ) }\end{array}$ & $A A$, Chelate-extraction & $1232-85$ & LC0016 & 1 \\
\hline 01034 & $\begin{array}{l}\text { Chromium, } \\
\text { total (ug/L as } C r)\end{array}$ & Digest, DCP, direct & $3229-87$ & LCO726 & 1 \\
\hline 01035 & $\begin{array}{l}\text { Cobalt, } \\
\text { dissolved (ug/L as Co) }\end{array}$ & $A E, I C P$, direct & $1472-85$ & $\mathrm{SH} 1043$ & 3 \\
\hline 01040 & $\begin{array}{l}\text { Copper, } \\
\text { dissolved (ug/L as } C u)\end{array}$ & $A E, I C P$, direct & $1472-85$ & $\mathrm{SH} 1043$ & 10 \\
\hline 01046 & $\begin{array}{l}\text { Iron, } \\
\text { dissolved (ug/L as } \mathrm{Fe} \text { ) }\end{array}$ & $A E, I C P$, direct & $1472-85$ & $\mathrm{SH} 1043$ & 3 \\
\hline 01045 & Iron, total (ug/L as $\mathrm{Fe})$ & Digest, $A A$, direct & $3381-85$ & LCO189 & 10 \\
\hline
\end{tabular}


Table 6. - Listing of analytical methods used at the National Water Quality Laboratory-Continued

\begin{tabular}{|c|c|c|c|c|c|}
\hline $\begin{array}{l}\text { Para- } \\
\text { meter } \\
\text { code }\end{array}$ & $\begin{array}{l}\text { Parameter name } \\
\text { phase and units }\end{array}$ & Method & $\begin{array}{l}\text { Method } \\
\text { number }\end{array}$ & $\begin{array}{l}\text { Laboratory } \\
\text { code }\end{array}$ & $\begin{array}{l}\text { Detection } \\
\text { limit }\end{array}$ \\
\hline \multicolumn{6}{|c|}{ TRACE ELEMENTS } \\
\hline 01130 & $\begin{array}{l}\text { Lithium, } \\
\quad \text { dissolved (ug/ } L \text { as } L i)\end{array}$ & $A E, I C P$, direct & $1472-85$ & $\mathrm{SH} 1043$ & 4 \\
\hline 01056 & $\begin{array}{l}\text { Manganese, } \\
\text { dissolved ( } u g / L \text { as } M n)\end{array}$ & $A E$, ICP, direct & $1472-85$ & $\mathrm{SH} 1043$ & 1 \\
\hline 71890 & $\begin{array}{l}\text { Mercury, } \\
\text { dissolved (ug/L as } \mathrm{Hg})\end{array}$ & AA, flameless, auto & $2462-85$ & LCO226 & .1 \\
\hline 01060 & $\begin{array}{l}\text { Molybdenum, } \\
\text { dissolved (ug/L as Mo) }\end{array}$ & $A E, I C P$, direct & $1472-85$ & $\mathrm{SH} 1043$ & 10 \\
\hline 01065 & $\begin{array}{l}\text { Nickel, } \\
\text { dissolved (ug/L as } \mathrm{Ni})\end{array}$ & $A E, I C P$, direct & $1472-88$ & $\mathrm{SH} 1043$ & 10 \\
\hline 01145 & $\begin{array}{l}\text { Selenium, } \\
\text { dissolved (ug/L as } \mathrm{Se} \text { ) }\end{array}$ & AA, hydride, auto & $2667-85$ & LC0087 & 1 \\
\hline 01147 & $\begin{array}{l}\text { Selenium, } \\
\text { total (ug/L as } \mathrm{Se} \text { ) }\end{array}$ & $A A$, hydride, auto & $4667-85$ & LC0286 & 1 \\
\hline 01075 & $\begin{array}{l}\text { Silver, } \\
\text { dissolved (ug/L as } \mathrm{Ag})\end{array}$ & $A E, I C P$, direct & $1472-85$ & $\mathrm{SH} 1043$ & 1 \\
\hline 01080 & $\begin{array}{l}\text { Strontium, } \\
\text { dissolved (ug/L as } S r)\end{array}$ & $A E, I C P$, direct & $1472-85$ & $\mathrm{SH} 1043$ & .5 \\
\hline 01085 & $\begin{array}{l}\text { Vanadium, } \\
\text { dissolved (ug/L as } V \text { ) }\end{array}$ & $A E, I C P$, direct & $1472-85$ & $\mathrm{SH} 1043$ & 6 \\
\hline \multirow[t]{2}{*}{01090} & Zinc, dissolved (ug/L as $Z n$ ) & $A E, I C P$, direct & $1472-85$ & $\mathrm{SH} 1043$ & 3 \\
\hline & & RADIATION AND RADIONUCLIDES & & & \\
\hline \multirow[t]{2}{*}{80030} & $\begin{array}{l}\text { Gross-alpha radioactivity, } \\
\text { dissolved, (ug/L as U natural) }\end{array}$ & Residue procedure & $1120-76$ & LCO444 & .4 \\
\hline & $\begin{array}{l}\text { Gross-alpha radioactivity, } \\
\text { dissolved, ( } \mathrm{pCi} / \mathrm{L} \text { as } \mathrm{Th})\end{array}$ & Residue procedure & $1120-76$ & LCO444 & .4 \\
\hline 80040 & $\begin{array}{l}\text { Gross-alpha radioactivity, } \\
\text { suspended, total (ug/L as } \\
\text { U natural) }\end{array}$ & Residue procedure & $7120-79$ & LC0456 & .4 \\
\hline 03515 & $\begin{array}{l}\text { Gross-beta radioactivity, } \\
\text { dissolved ( } \mathrm{pCi} / \mathrm{L} \text { as } \mathrm{Cs}-137)\end{array}$ & Residue procedure & $1120-76$ & LC0455 & .4 \\
\hline 80050 & $\begin{array}{l}\text { Gross-beta radioactivity, } \\
\text { dissolved (pCi/L as Sr/Yt-90) }\end{array}$ & Residue procedure & $1120-76$ & LCO445 & .4 \\
\hline 03516 & $\begin{array}{l}\text { Gross-beta radioactivity } \\
\text { suspended, total ( } \mathrm{pC} \mathrm{i} / \mathrm{L} \text { as } \mathrm{Cs}-137)\end{array}$ & Residue procedure & $7120-79$ & LCO446 & .4 \\
\hline 80060 & $\begin{array}{l}\text { Gross-beta radioact ivity, } \\
\text { suspended, total ( } \mathrm{pCi} / \mathrm{L} \text { as } \mathrm{Sr} / \mathrm{Yt}-90 \text { ) }\end{array}$ & Residue procedure & $1120-76$ & LCO447 & .4 \\
\hline
\end{tabular}


Table 6. - Listing of conalytical methods used at the National Water Quality Laboratory-Cont inued

\begin{tabular}{|c|c|c|c|c|c|}
\hline $\begin{array}{l}\text { Para- } \\
\text { meter } \\
\text { code }\end{array}$ & $\begin{array}{l}\text { Parameter name } \\
\text { phase and units }\end{array}$ & Method & $\begin{array}{l}\text { Method } \\
\text { number }\end{array}$ & $\begin{array}{l}\text { Laboratory } \\
\text { code }\end{array}$ & $\begin{array}{l}\text { Detection } \\
\text { I imit }\end{array}$ \\
\hline & & RADIATION AND RADIONUCLIDES & & & \\
\hline 09511 & $\begin{array}{l}\text { Radium } 226 \text {, } \\
\text { dissolved ( } \mathrm{pCi} / \mathrm{L} \text { as } \mathrm{Ra}-226)\end{array}$ & Radon emanation & $1141-76$ & LC0794 & .01 \\
\hline 81366 & $\begin{array}{l}\text { Radium } 228 \text {, } \\
\text { dissolved ( } \mathrm{pCi} / \mathrm{L} \text { as } \mathrm{Ra}-228)\end{array}$ & Separation, beta count & - & LC1363 & 1.0 \\
\hline 82303 & $\begin{array}{l}\text { Radon } 222, \\
\text { total ( } \mathrm{pCi} / \mathrm{L} \text { as } \mathrm{Rn} 222)\end{array}$ & Liquid scintillation & - & LC1369 & 80 \\
\hline 07000 & $\begin{array}{l}\text { Tritium, } \\
\text { total }(\mathrm{pCi} / \mathrm{L})\end{array}$ & Electro enrichment, gas & $1174-76$ & LC1043 & .2 \\
\hline 22610 & $\begin{array}{l}\text { Uranium-234, } \\
\text { water, dissolved }(p C i / L)\end{array}$ & Alpha spectrometry & - & LC1366 & .1 \\
\hline 22703 & $\begin{array}{l}\text { Uranium-235, } \\
\quad \text { dissolved }(\mathrm{pCi} / \mathrm{L})\end{array}$ & Alpha spectrometry & - & LC1367 & .1 \\
\hline 22603 & $\begin{array}{l}\text { Uranium-238, } \\
\quad \text { dissolved }(p C i / L)\end{array}$ & Alpha spectrometry & - & LC1368 & .1 \\
\hline 22703 & $\begin{array}{l}\text { Uranium, } \\
\text { natural, dissolved (ug/L as } U \text { ) }\end{array}$ & Calculated & - & - & .3 \\
\hline 28011 & $\begin{array}{l}\text { Uranium, } \\
\text { natural, total (ug/L as } U \text { ) }\end{array}$ & Fluorimetry, direct & - & LC1365 & 1.0 \\
\hline & & STABLE ISOTOPES & & & \\
\hline 82081 & $\begin{array}{l}\text { Carbon-13/carbon- } 12 \\
\delta \text { in permil relative to PDB }\end{array}$ & $\begin{array}{l}\text { Conversion to } \mathrm{CO}_{2} \text { with orthophosphoric } \\
\text { acid, mass spectrometry }\end{array}$ & - & LCO440 & .15 \\
\hline 82082 & $\begin{array}{l}\text { Hydrogen- } 2 / \text { hydrogen- } \\
\delta \text { in permil relative to SMOW }\end{array}$ & $\begin{array}{l}\text { Conversion to } \mathrm{H}_{2} \text { by reaction with zinc } \\
\text { metal, mass spectrometry }\end{array}$ & - & LCO300 & 1.5 \\
\hline 82085 & $\begin{array}{l}\text { Oxygen-18/oxygen-16 } \\
\delta \text { in permil relative to SMOW }\end{array}$ & Equilibration with $\mathrm{CO}_{2}$, mass spectrometry & - & LC0489 & .15 \\
\hline 82086 & $\begin{array}{l}\text { Sulfur-34/sulfur-32 } \\
\delta \text { in permil relative to CDT }\end{array}$ & $\begin{array}{l}\text { Precipitation of } \mathrm{BaSO}_{4} \text { by addition of } \mathrm{BaCl}_{2} \text {, } \\
\text { conversion to } \mathrm{SO}_{2} \text { by roasting with } \mathrm{Cu}_{2} \mathrm{O} \\
\text { and } \mathrm{SiO}_{2} \text {, mass spectrometry }\end{array}$ & - & LCO298 & 1.0 \\
\hline
\end{tabular}


Table 7.-Properties and major constitwents of water from NoTs test holes

[Sampling depth, center of sampling interval below land surface; us/cm, microsiemens per centimeter; ${ }^{\circ} \mathrm{C}$, degrees Celcius; field, analysis conducted at the sampling site; $\mathrm{g} / \mathrm{ml}$, grams per milliliter; dissolved, concentration measured in filtered sample except

dissolved oxygen, which is measured in unfiltered flowing water; -, indicates no data are available; mg/L, milligrams per liter;

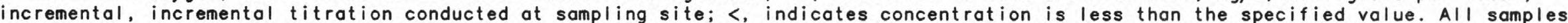
analyzed by the National Water Quality Laboratory of the U.S. Geological Survey with the exception of analyses conducted at the sampling site]

\begin{tabular}{|c|c|c|c|c|c|c|c|c|c|}
\hline \multirow[b]{2}{*}{$\begin{array}{l}\text { Test-hole } \\
\text { name }\end{array}$} & \multirow[b]{2}{*}{$\begin{array}{l}\text { Local } \\
\text { identifier }\end{array}$} & \multirow[b]{2}{*}{$\begin{array}{l}\text { Sampling } \\
\text { depth } \\
(\text { feet })\end{array}$} & \multicolumn{7}{|c|}{ Water properties } \\
\hline & & & $\begin{array}{c}\text { Specific } \\
\text { conductance, } \\
\text { field } \\
(\text { uS } / \mathrm{cm})\end{array}$ & $\begin{array}{l}\text { Specific } \\
\text { conductance, } \\
\text { laboratory } \\
\text { (uS/cm } \\
\left.\text { at } 25{ }^{\circ} \mathrm{C}\right)\end{array}$ & $\begin{array}{c}\mathrm{pH}, \\
\text { field } \\
\text { (standard } \\
\text { units) }\end{array}$ & $\begin{array}{l}\mathrm{pH}, \\
\text { laboratory } \\
\text { (standard } \\
\text { units) }\end{array}$ & $\begin{array}{l}\text { Water } \\
\text { temperature, } \\
\text { field } \\
\left({ }^{\circ} \mathrm{C}\right)\end{array}$ & $\begin{array}{l}\text { Density, } \\
(\mathrm{g} / \mathrm{ml} \\
\left.\text { at } 25{ }^{\circ} \mathrm{C}\right)\end{array}$ & $\begin{array}{l}\text { Oxygen, } \\
\text { dissolved, } \\
\text { field } \\
(\mathrm{mg} / \mathrm{L})\end{array}$ \\
\hline
\end{tabular}

NOTS $1 \mathrm{~A} \quad 16 \mathrm{~N}-02 \mathrm{~W}-21$ BAA $3 \quad 176$

NOTS $2 \quad 15 \mathrm{~N}-03 \mathrm{E}-31$ BAA $2 \quad 106.4$

NOTS $3 \quad 14 \mathrm{~N}-02 \mathrm{~W}-23 \operatorname{CCA} 1 \quad 119.5$

119.5

164.9

NOTS $4 \quad 10 \mathrm{~N}-01 \mathrm{E}-11$ BBB $1 \quad 101.0$

156.2

189.0

257.5

NOTS $5 \quad 08 \mathrm{~N}-03 E-03$ DAA $1 \quad 62.0$

62.0

131.0

183.5

NOTS 6

14N-03W-07 DAA $2 \quad 106.2$

141.0

180.8

180.8

222.8

276.2

296.2

327.1

475.1

NOTS 7

O9N-02W-29 DCA 5

NOTS 7A
330.1

407.5

480.0

480.0
607

907

630

855

791

566

566

666

402

410

388

433

984

984
989
400

12,400

. 600

8,210

\section{9}

603

523

523

490

490

490

1,160

\section{0}

856

856
736
599

599
599
8,910

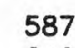

612

528

526

500

438
499

499

1,170

608

858
752
633

633
627

\section{8}

8.9

9.0

7.3

7.3

8.9

7.7

7.7

7.8

7.7

7.5

8.2

7.5
7.4

7.4

7.6

7.6
7.6

8.0

7.7

8.0
8.6

9.6

9.1

9.3

9.3
8.7

8.9

9.1

7.6

7.6

8.0

7.7

7. 6

7.6
7.7

7.8

7.6

7.7

7.8

7.9

7.7
7.4

7.4

7.8

7.6
7.7

7.8

7.9

8.0

8.4

9.1

8.9

9.2
9.2

17.5
18.0
20.0
16.5
16.5
17.5
17.5
17.5
17.5
17.5
18.0
18.0
19.5
18.0
17.5
17.0
17.5
17.5
17.5
18.0
17.0
18.0
18.0
17.0
17.5
18.5
18.5
18.5

$=$

1.7

0.2

1.0

8.0
8.0

6.0

3.7

5.5

5.2

3. 6

0.8

0.8

0.8

0.1

8.0 
Table 7.-Properties and major constituents of water from NoTS test holes - Cont inued

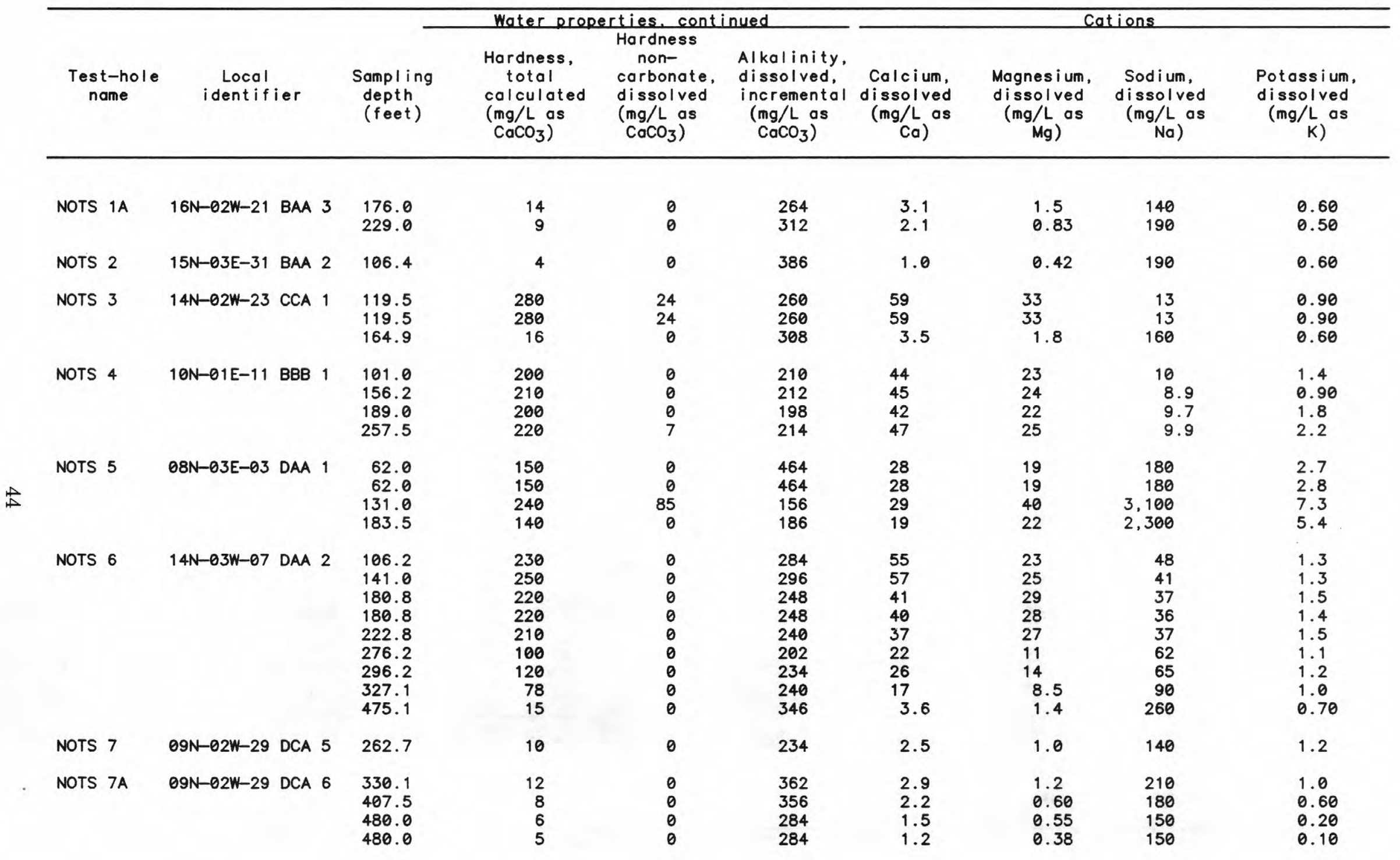


Table 7. - Properties and major constituents of water from NoTS test holes -Cont inued

\begin{tabular}{|c|c|c|c|c|c|c|c|c|c|}
\hline $\begin{array}{l}\text { Test-hole } \\
\text { name }\end{array}$ & $\begin{array}{c}\text { Local } \\
\text { identifier }\end{array}$ & $\begin{array}{l}\text { Sampling } \\
\text { depth } \\
(f \text { eet })\end{array}$ & $\begin{array}{l}\text { Bicarbonate, } \\
\text { dissolved, } \\
\text { incrementai } \\
\text { (mg/L as } \\
\left.\mathrm{HCO}_{3}\right)\end{array}$ & $\begin{array}{l}\text { Carbonate, } \\
\text { dissolved, } \\
\text { incremental } \\
(\mathrm{mg} / \mathrm{L} \text { as } \\
\left.\mathrm{CO}_{3}\right)\end{array}$ & $\begin{array}{l}\text { Sulfate, } \\
\text { dissolved } \\
(\mathrm{mg} / \mathrm{L} \text { as } \\
\left.\mathrm{SO}_{4}\right)\end{array}$ & $\begin{array}{l}\text { Anions } \\
\text { Chloride, } \\
\text { dissolved } \\
\text { (mg/L as } \\
\text { Cl })\end{array}$ & $\begin{array}{l}\text { Fluoride, } \\
\text { dissolved } \\
(\mathrm{mg} / \mathrm{L} \text { as } \\
\mathrm{F})\end{array}$ & $\begin{array}{l}\text { Bromide, } \\
\text { dissolved } \\
\text { (mg/L as } \\
B r)\end{array}$ & $\begin{array}{c}\text { Iodide, } \\
\text { dissolved } \\
(\mathrm{mg} / \mathrm{L} \text { as } \\
\mathrm{I})\end{array}$ \\
\hline NOTS $1 \mathrm{~A}$ & $16 \mathrm{~N}-02 \mathrm{~W}-21$ BAA & $\begin{array}{l}176.0 \\
229.0\end{array}$ & $\begin{array}{l}303 \\
354\end{array}$ & $\begin{array}{l}10 \\
12\end{array}$ & $\begin{array}{l}27 \\
39\end{array}$ & $\begin{array}{l}29 \\
54\end{array}$ & $\begin{array}{l}0.80 \\
0.30\end{array}$ & $0.1 \overline{6}$ & 二 \\
\hline NOTS 2 & $15 \mathrm{~N}-03 \mathrm{E}-31 \mathrm{BAA}$ & 106.4 & 422 & 24 & 12 & 13 & 0.50 & 0.086 & - \\
\hline NOTS 3 & $14 \mathrm{~N}-02 \mathrm{~W}-23 \mathrm{CCA}$ & $\begin{array}{l}119.5 \\
119.5 \\
164.9\end{array}$ & $\begin{array}{l}317 \\
317 \\
371\end{array}$ & $\begin{array}{l}0 \\
0 \\
2\end{array}$ & $\begin{array}{l}25 \\
25 \\
20\end{array}$ & $\begin{array}{l}12 \\
12 \\
13\end{array}$ & $\begin{array}{l}0.30 \\
0.30 \\
0.30\end{array}$ & $\begin{array}{l}0.15 \\
0.14 \\
0.17\end{array}$ & $\overline{-}$ \\
\hline NOTS 4 & $10 \mathrm{~N}-01 \mathrm{E}-11 \mathrm{BBB}$ & $\begin{array}{l}101.0 \\
156.2 \\
189.0 \\
257.5\end{array}$ & $\begin{array}{l}256 \\
259 \\
242 \\
261\end{array}$ & $\begin{array}{l}0 \\
0 \\
0 \\
0\end{array}$ & $\begin{array}{c}4.2 \\
4.8 \\
17 \\
6.9\end{array}$ & $\begin{array}{l}5.8 \\
7.2 \\
5.1 \\
9.3\end{array}$ & $\begin{array}{l}0.20 \\
0.30 \\
0.30 \\
0.30\end{array}$ & $\begin{array}{l}0.064 \\
0.080 \\
0.041 \\
0.064\end{array}$ & $\bar{z}$ \\
\hline NOTS 5 & $08 \mathrm{~N}-03 E-03 \mathrm{DAA}$ & $\begin{array}{r}62.0 \\
62.0 \\
131.0 \\
183.5\end{array}$ & $\begin{array}{l}566 \\
566 \\
190 \\
227\end{array}$ & $\begin{array}{l}\dot{0} \\
0 \\
0 \\
0\end{array}$ & $\begin{array}{r}34 \\
35 \\
5,100 \\
4,700\end{array}$ & $\begin{array}{r}31 \\
31 \\
1,300 \\
150\end{array}$ & $\begin{array}{l}0.40 \\
0.50 \\
2.3 \\
2.3\end{array}$ & $\begin{array}{l}0.22 \\
0.20 \\
4.1 \\
0.57\end{array}$ & $\begin{array}{r}\overline{-} \\
0.099 \\
0.020\end{array}$ \\
\hline NOTS 6 & $14 \mathrm{~N}-03 \mathrm{~W}-07$ DAA & $\begin{array}{l}106.2 \\
141.0 \\
180.8 \\
180.8 \\
222.8 \\
276.2 \\
296.2 \\
327.1 \\
475.1\end{array}$ & $\begin{array}{l}346 \\
361 \\
302 \\
302 \\
293 \\
246 \\
285 \\
293 \\
398\end{array}$ & $\begin{array}{r}0 \\
0 \\
0 \\
0 \\
0 \\
0 \\
0 \\
0 \\
12\end{array}$ & $\begin{array}{l}18 \\
18 \\
18 \\
13 \\
11 \\
14 \\
10 \\
9.9 \\
72\end{array}$ & $\begin{array}{c}9.9 \\
11 \\
12 \\
12 \\
11 \\
11 \\
13 \\
11 \\
110\end{array}$ & $\begin{array}{l}0.30 \\
0.20 \\
0.30 \\
0.30 \\
0.20 \\
0.20 \\
0.20 \\
0.20 \\
1.6\end{array}$ & $\begin{array}{l}0.051 \\
0.063 \\
0.039 \\
0.038 \\
0.037 \\
0.049 \\
0.046 \\
0.073 \\
0.21\end{array}$ & $\begin{array}{l}= \\
= \\
= \\
=\end{array}$ \\
\hline NOTS 7 & $09 \mathrm{~N}-02 \mathrm{~W}-29 \mathrm{DCA}$ & 262.7 & 256 & 15 & 44 & 16 & 1.0 & 0.31 & - \\
\hline NOTS $7 \mathrm{~A}$ & $09 \mathrm{~N}-02 \mathrm{~W}-29 \mathrm{DCA}$ & $\begin{array}{l}330.1 \\
407.5 \\
480.0 \\
480.0\end{array}$ & $\begin{array}{l}373 \\
322 \\
283 \\
283\end{array}$ & $\begin{array}{l}34 \\
56 \\
32 \\
32\end{array}$ & $\begin{array}{l}76 \\
25 \\
17 \\
18\end{array}$ & $\begin{array}{r}14 \\
6.8 \\
6.2 \\
8.2\end{array}$ & $\begin{array}{l}1.2 \\
0.30 \\
0.40 \\
0.50\end{array}$ & $\begin{array}{l}0.17 \\
0.13 \\
0.060 \\
0.20\end{array}$ & $\bar{z}$ \\
\hline
\end{tabular}


Table 7.- Properties and major constituents of water from NOTS test holes - Cont inued

\begin{tabular}{|c|c|c|c|c|c|c|c|c|c|}
\hline \multirow[b]{2}{*}{$\begin{array}{c}\text { Test-hole } \\
\text { name }\end{array}$} & \multirow[b]{2}{*}{$\begin{array}{c}\text { Local } \\
\text { identifier }\end{array}$} & \multirow[b]{2}{*}{$\begin{array}{l}\text { Sampling } \\
\text { depth } \\
(\text { feet })\end{array}$} & \multirow[b]{2}{*}{$\begin{array}{c}\text { Anion } \\
\text { Silica, } \\
\text { dissolved } \\
\left(\mathrm{mg} / \mathrm{L}^{\text {as }}\right. \\
\left.\mathrm{SiO}_{2}\right)\end{array}$} & \multicolumn{4}{|c|}{ Nutrients } & \multirow[b]{2}{*}{$\begin{array}{c}\text { Carbon } \\
\text { Organic } \\
\text { carbon, } \\
\text { dissolved } \\
(\mathrm{mg} / \mathrm{L} \text { as } \\
\text { C) }\end{array}$} & \\
\hline & & & & $\begin{array}{c}\text { Nitrogen, } \\
\text { nitrite } \\
(\mathrm{mg} / \mathrm{L} \text { as } \\
\mathrm{N})\end{array}$ & $\begin{array}{c}\text { Nitrite } \\
\text { plus } \\
\text { nitrate, } \\
\text { dissolved } \\
(\mathrm{mg} / \mathrm{L} \text { as } \\
\mathrm{N})\end{array}$ & $\begin{array}{l}\text { Nitrogen, } \\
\text { ammonia } \\
\text { dissolved } \\
(\mathrm{mg} / \mathrm{L} \text { as } \\
\mathrm{N})\end{array}$ & $\begin{array}{c}\text { Phosphorous, } \\
\text { ortho- } \\
\text { phosphate, } \\
\text { dissolved } \\
\text { (mg/L as } \\
\text { P) }\end{array}$ & & \\
\hline NOTS $1 \mathrm{~A}$ & $16 \mathrm{~N}-02 \mathrm{~W}-21 \mathrm{BAA}$ & $\begin{array}{l}176.0 \\
229.0\end{array}$ & $\begin{array}{l}11 \\
10\end{array}$ & $\begin{array}{l}<0.010 \\
<0.010\end{array}$ & $\begin{array}{l}0.350 \\
0.510\end{array}$ & $\begin{array}{r}<0.010 \\
0.010\end{array}$ & $\begin{array}{l}0.020 \\
0.020\end{array}$ & $\begin{array}{l}1.4 \\
0.8\end{array}$ & \\
\hline NOTS 2 & $15 N-03 E-31$ BAA & 106.4 & 9.5 & $<0.010$ & $<0.100$ & 0.100 & 0.020 & 0.8 & \\
\hline NOTS 3 & $14 \mathrm{~N}-02 \mathrm{~W}-23 \mathrm{CCA}$ & $\begin{array}{l}119.5 \\
119.5 \\
164.9\end{array}$ & $\begin{array}{l}19 \\
19 \\
9.3\end{array}$ & $\begin{array}{l}<0.010 \\
<0.010 \\
<0.010\end{array}$ & $\begin{array}{l}2.80 \\
2.80 \\
2.10\end{array}$ & $\begin{array}{r}0.010 \\
0.010 \\
<0.010\end{array}$ & $\begin{array}{r}0.040 \\
0.040 \\
<0.010\end{array}$ & $\begin{array}{l}0.9 \\
0.8 \\
1.2\end{array}$ & \\
\hline NOTS 4 & $10 \mathrm{~N}-01 \mathrm{E}-11 \mathrm{BBB}$ & $\begin{array}{l}101.0 \\
156.2 \\
189.0 \\
257.5\end{array}$ & $\begin{array}{c}13 \\
15 \\
9.6 \\
11\end{array}$ & $\begin{array}{l}<0 . \overline{10} \\
<0.010 \\
<0.010\end{array}$ & $\begin{array}{l}0 . \overline{110} \\
0.150 \\
0.280\end{array}$ & $\begin{array}{r}<0.010 \\
<0.010 \\
0.030\end{array}$ & $\begin{array}{l}0 . \overline{40} \\
0.020 \\
0.010\end{array}$ & $\begin{array}{l}0.9 \\
0.8 \\
0.8 \\
0.7\end{array}$ & \\
\hline NOTS 5 & $08 N-03 E-03$ DAA & $\begin{array}{r}62.0 \\
62.0 \\
131.0 \\
183.5\end{array}$ & $\begin{array}{l}15 \\
15 \\
17 \\
19\end{array}$ & $\begin{array}{l}<0.010 \\
<0.010 \\
<0.010\end{array}$ & $\begin{array}{r}0.450 \\
<0.100 \\
<0.100\end{array}$ & $\begin{array}{l}<0.010 \\
1.50 \\
0.720\end{array}$ & $\begin{array}{l}<0.010 \\
<0.010 \\
<0.010\end{array}$ & $\begin{array}{l}1.3 \\
1.0 \\
0.8 \\
0.7\end{array}$ & \\
\hline NOTS 6 & $14 N-03 W-07$ DAA & $\begin{array}{l}106.2 \\
141.0 \\
180.8 \\
180.8 \\
222.8 \\
276.2 \\
296.2 \\
327.1 \\
475.1\end{array}$ & $\begin{array}{l}22 \\
23 \\
21 \\
21 \\
20 \\
17 \\
18 \\
15 \\
11\end{array}$ & $\begin{array}{r}0.260 \\
<0.010 \\
<0.010 \\
0.010 \\
<0.010 \\
<0.010 \\
<0.010 \\
<0.010 \\
0.020\end{array}$ & $\begin{array}{l}1.20 \\
1.40 \\
0.940 \\
0.970 \\
0.790 \\
0.950 \\
0.710 \\
0.850 \\
0.470\end{array}$ & $\begin{array}{r}0.020 \\
<0.010 \\
<0.010 \\
<0.010 \\
<0.010 \\
<0.010 \\
0.010 \\
0.170 \\
<0.010\end{array}$ & $\begin{array}{l}<0.010 \\
<0.010 \\
<0.010 \\
<0.010 \\
<0.010 \\
<0.010 \\
<0.010 \\
<0.010 \\
0.030\end{array}$ & $\begin{array}{l}1.0 \\
0.6 \\
0.5 \\
0.7 \\
4.8 \\
0.3 \\
0.4 \\
0.6 \\
0.4\end{array}$ & \\
\hline NOTS 7 & $09 N-02 W-29 \mathrm{DCA}$ & 262.7 & 7.1 & - & - & - & - & - & \\
\hline NOTS $7 A$ & $09 N-02 W-29$ DCA & $\begin{array}{l}330.1 \\
407.5 \\
480.0 \\
480.0\end{array}$ & $\begin{array}{l}9.0 \\
6.3 \\
6.7 \\
6.5\end{array}$ & $\begin{array}{r}<0.010 \\
0.090 \\
0.060 \\
0.060\end{array}$ & $\begin{array}{r}0.130 \\
0.220 \\
<0.100 \\
<0.100\end{array}$ & $\begin{array}{r}0.110 \\
0.010 \\
0.010 \\
<0.010\end{array}$ & $\begin{array}{l}0.050 \\
0.010 \\
0.010 \\
0.010\end{array}$ & $\begin{array}{r}1.6 \\
1.7 \\
3.5 \\
-\end{array}$ & \\
\hline
\end{tabular}


Table 8.-Concentrations of trace elements in water from NoTs test holes

[Sampling depth, center of sampling interval below land surface; <, indicates concentration is less than the specified value; ug/L, micrograms per liter; - indicates no data are available; * indicates possible contamination during sampling. All samples analyzed by the National Water Quality Laboratory of the U.S. Geological Survey]

\begin{tabular}{|c|c|c|c|c|c|c|c|c|c|}
\hline $\begin{array}{c}\text { Test-hole } \\
\text { name }\end{array}$ & $\begin{array}{c}\text { Local } \\
\text { identifier }\end{array}$ & $\begin{array}{l}\text { Sampling } \\
\text { depth } \\
(\text { feet })\end{array}$ & $\begin{array}{l}\text { Al umi num, } \\
\text { disso/ved } \\
\text { (ug/L } \\
\text { as } A \mid \text { ) }\end{array}$ & $\begin{array}{l}\text { Al umi num, } \\
\text { total } \\
\text { (ug/L } \\
\text { as } \mathrm{Al} \text { ) }\end{array}$ & $\begin{array}{l}\text { Barium, } \\
\text { dissolved } \\
\text { (ug/L } \\
\text { as } B a \text { ) }\end{array}$ & $\begin{array}{l}\text { Beryl I ium, } \\
\text { dissolved } \\
\text { (ug/L } \\
\text { as } \mathrm{Be} \text { ) }\end{array}$ & $\begin{array}{c}\text { Boron, } \\
\text { dissolved } \\
\text { (ug/L } \\
\text { as } B \text { ) }\end{array}$ & $\begin{array}{l}\text { Cadmi um, } \\
\text { dissol ved } \\
\text { (ug/L } \\
\text { as Cd) }\end{array}$ & $\begin{array}{l}\text { Cobalt, } \\
\text { dissol ved } \\
\text { (ug/L }\end{array}$ \\
\hline NOTS $1 \mathrm{~A}$ & $16 \mathrm{~N}-02 \mathrm{~W}-21$ BAA 3 & $\begin{array}{l}176.0 \\
229.0\end{array}$ & $\begin{array}{l}30 \\
60\end{array}$ & $\begin{array}{r}5,300 \\
14,000\end{array}$ & $\begin{array}{l}54 \\
40\end{array}$ & $\begin{array}{l}1 \\
3\end{array}$ & $\begin{array}{l}2,100 \\
2,600\end{array}$ & $\begin{array}{l}<1.0 \\
<1.0\end{array}$ & $\begin{array}{l}<3 \\
<3\end{array}$ \\
\hline NOTS 2 & $15 N-03 E-31$ BAA 2 & 106.4 & 70 & 3,700 & 15 & 0.9 & 1,400 & $<1.0$ & $<3$ \\
\hline NOTS 3 & $14 \mathrm{~N}-02 \mathrm{~W}-23 \mathrm{CCA} 1$ & $\begin{array}{l}119.5 \\
119.5 \\
164.9\end{array}$ & $\begin{array}{l}<10 \\
<10 \\
<10\end{array}$ & $\begin{array}{r}10 \\
20 \\
5,500\end{array}$ & $\begin{array}{r}270 \\
270 \\
38\end{array}$ & $\begin{array}{l}<0.5 \\
<0.5 \\
<0.5\end{array}$ & $\begin{array}{r}50 \\
50 \\
1,300\end{array}$ & $\begin{array}{l}<1.0 \\
<1.0 \\
<1.0\end{array}$ & $\begin{array}{l}<3 \\
<3 \\
<3\end{array}$ \\
\hline NOTS 4 & $10 \mathrm{~N}-01 \mathrm{E}-11$ BBB 1 & $\begin{array}{l}101.0 \\
156.2 \\
189.0 \\
257.5\end{array}$ & $\begin{array}{l}<10 \\
<10 \\
<10 \\
<10\end{array}$ & $\begin{array}{r}230 \\
90 \\
50 \\
400\end{array}$ & $\begin{array}{l}320 \\
180 \\
250 \\
350\end{array}$ & $\begin{array}{l}<0.5 \\
<0.5 \\
<0.5 \\
<0.5\end{array}$ & $\begin{array}{r}80 \\
80 \\
80 \\
100\end{array}$ & $\begin{array}{l}<1.0 \\
<1.0 \\
<1.0 \\
<1.0\end{array}$ & $\begin{array}{l}<3 \\
<3 \\
<3 \\
<3\end{array}$ \\
\hline NOTS 5 & $08 N-03 E-03$ DAA 1 & $\begin{array}{r}62.0 \\
62.0 \\
131.0 \\
183.5\end{array}$ & $\begin{array}{l}<10 \\
<10 \\
<10 \\
<10\end{array}$ & $\begin{array}{r}<10 \\
30 \\
2,400 \\
1,200\end{array}$ & $\begin{array}{r}170 \\
180 \\
<100 \\
<100\end{array}$ & $\begin{aligned} &<0.5 \\
&<0.5 \\
&<10 \\
&<10\end{aligned}$ & $\begin{array}{l}1,300 \\
1,300 \\
7,400 \\
6,700\end{array}$ & $\begin{array}{l}<1.0 \\
<1.0 \\
<1.0 \\
<1.0\end{array}$ & $\begin{array}{l}<3 \\
<3 \\
<1 \\
1\end{array}$ \\
\hline NOTS 6 & $14 N-03 W-07$ DAA 2 & $\begin{array}{l}106.2 \\
141.0 \\
180.8 \\
180.8 \\
222.8 \\
276.2 \\
296.2 \\
327.1 \\
475.1\end{array}$ & $\begin{array}{l}<10 \\
<10 \\
<10 \\
<10 \\
<10 \\
<10 \\
<10 \\
<10 \\
20\end{array}$ & $\begin{array}{r}50 \\
60 \\
40 \\
40 \\
30 \\
30 \\
60 \\
900 \\
12,000\end{array}$ & $\begin{array}{r}280 \\
280 \\
220 \\
220 \\
210 \\
160 \\
230 \\
220 \\
28\end{array}$ & $\begin{array}{l}<0.5 \\
<0.5 \\
<0.5 \\
<0.5 \\
<0.5 \\
<0.5 \\
<0.5 \\
<0.5 \\
3\end{array}$ & $\begin{array}{r}320 \\
290 \\
330 \\
330 \\
340 \\
1,000 \\
540 \\
680 \\
3,400\end{array}$ & $\begin{array}{r}<1.0 \\
1.0 \\
4.0 \\
2.0 \\
<1.0 \\
<1.0 \\
<1.0 \\
<1.0 \\
<1.0\end{array}$ & $\begin{array}{l}<3 \\
<3 \\
<3 \\
<3 \\
<3 \\
<3 \\
<3 \\
<3 \\
<3\end{array}$ \\
\hline NOTS 7 & $09 N-02 W-29$ DCA 5 & 262.7 & 140 & 83,000 & 16 & $<0.5$ & 2,400 & $<1.0$ & $<3$ \\
\hline NOTS $7 \mathrm{~A}$ & $09 \mathrm{~N}-02 \mathrm{~W}-29 \mathrm{DCA} 6$ & $\begin{array}{l}330.1 \\
407.5 \\
480.0 \\
480.0\end{array}$ & $\begin{array}{r}<10 \\
10 \\
30 \\
<10\end{array}$ & $\begin{array}{r}2,200 \\
7,500 \\
15,000 \\
11,000\end{array}$ & $\begin{array}{l}13 \\
39 \\
33 \\
31\end{array}$ & $\begin{array}{l}<0.5 \\
<0.5 \\
<0.5 \\
<0.5\end{array}$ & $\begin{array}{r}3,700 \\
1,500 \\
760 \\
710\end{array}$ & $\begin{array}{l}<1.0 \\
<1.0 \\
<1.0 \\
<1.0\end{array}$ & $\begin{array}{l}<3 \\
<3 \\
<3 \\
<3\end{array}$ \\
\hline
\end{tabular}


Table 8. - Concentrations of trace elements in water from NaTS test holes-Cont inued

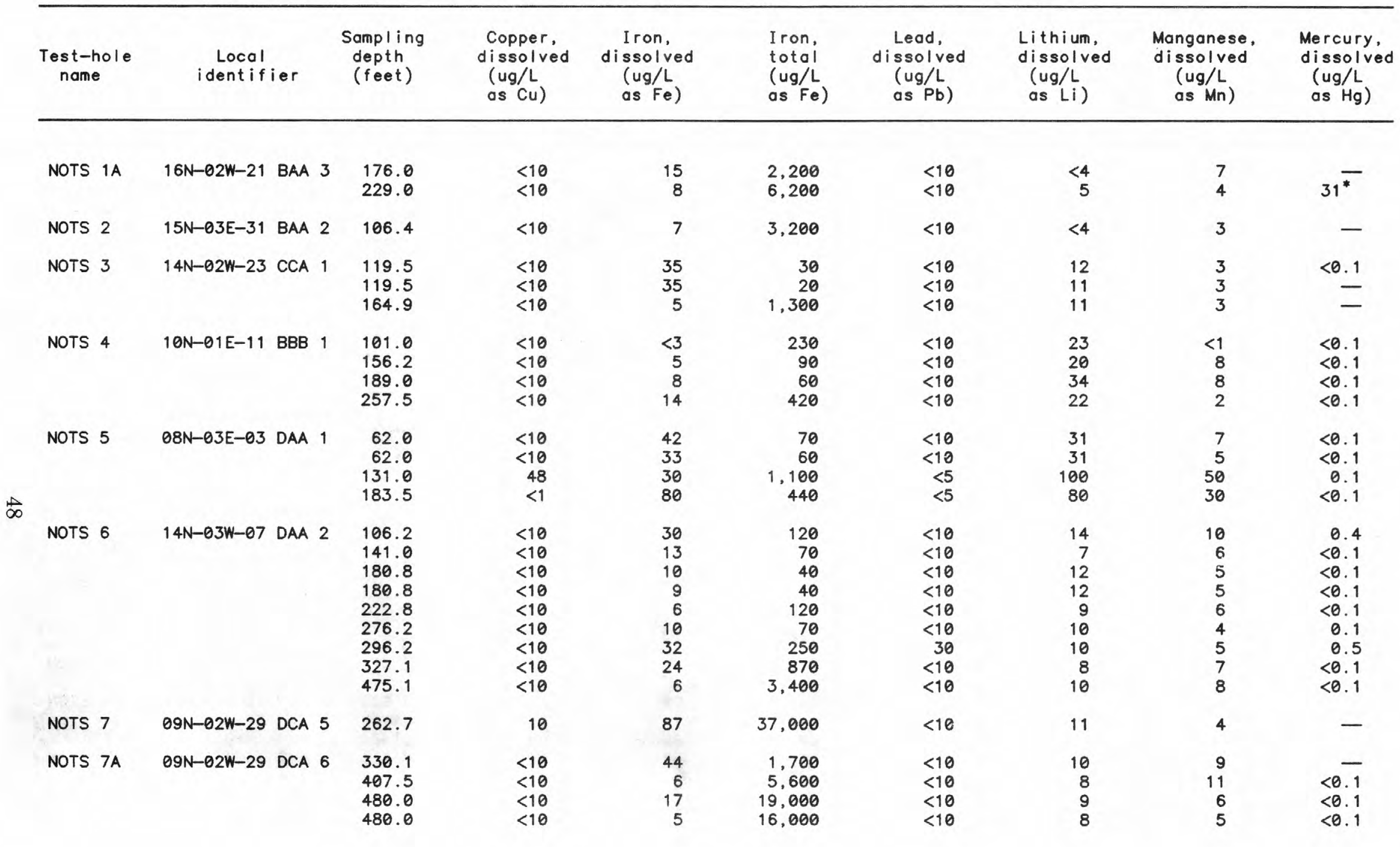


Table 8.-Concentrations of trace elements in water from NOTS test holes-Cont inued

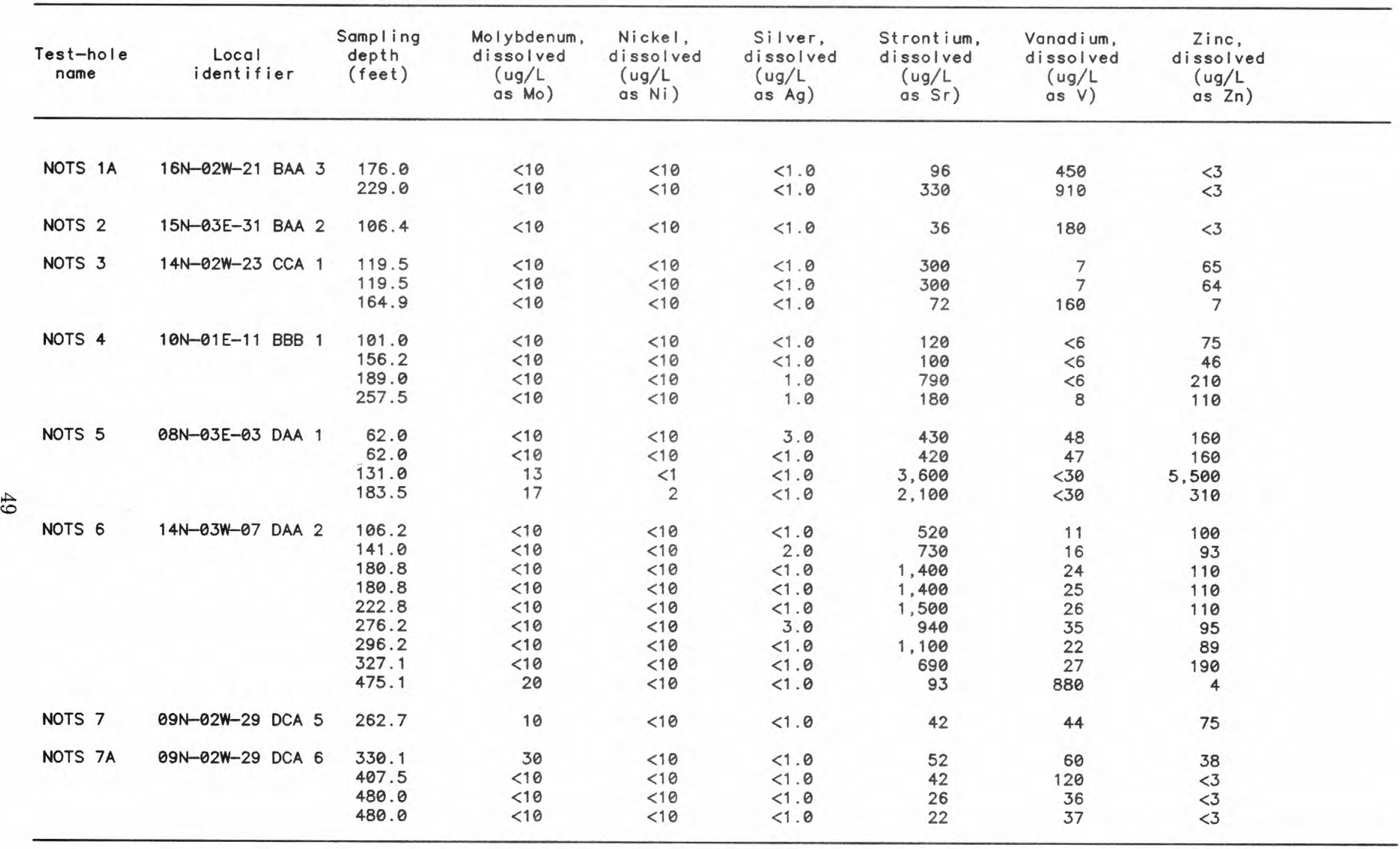


Table 9.-Concentrations of arsenic in water from NOTS test holes

[Sampling depth, center of sampling interval below land surface; *, analyzed by Battelle Pacific Northwest Division, Marine Sciences Laboratory, Sequim. Woshington; **, analyzed by the Branch of Regional Research,

Western Region of the U.S. Geological Survey, Water Resources Division, Menlo Park, California;

$\mathrm{ug} / \mathrm{L}$, micrograms per liter; <, indicates concentration is less than the specified value; -, indicates no data are available. All samples analyzed by the National Water Quality Laboratory of the U.S. Geological Survey unless otherwise noted]

\begin{tabular}{|c|c|c|c|c|c|c|c|c|}
\hline $\begin{array}{c}\text { Test-hole } \\
\text { name }\end{array}$ & $\begin{array}{l}\text { Local } \\
\text { identifier }\end{array}$ & $\begin{array}{l}\text { Sampl ing } \\
\text { depth } \\
\text { (feet) }\end{array}$ & $\begin{array}{c}\text { Arsenic, } \\
\text { dissolved, } \\
\text { (ug/L as As) }\end{array}$ & $\begin{array}{c}\text { Arsenic, } \\
\text { total, } \\
\text { (ug/L as As) }\end{array}$ & $\begin{array}{l}\text { Arsenic, } \\
\text { dissolved, } \\
\text { (ug/L as As) }\end{array}$ & $\begin{array}{r}\text { Arsen } \\
\text { HAs } \\
\text { disso } \\
\text { (ug/L }\end{array}$ & $\begin{array}{l}\text { nate, } \\
\mathrm{sO}_{4}= \\
\text { olved, } \\
\text { as As) }\end{array}$ & $\begin{array}{c}\text { Arsenite, } \\
\mathrm{AsO}_{2}- \\
\text { dissolved, } \\
\text { (ug/L as As) }\end{array}$ \\
\hline NOTS $1 \mathrm{~A}$ & $16 N-02 W-21$ BAA 3 & $\begin{array}{l}176.0 \\
229.0\end{array}$ & $\begin{array}{l}53 \\
69\end{array}$ & $\begin{array}{l}56 \\
65\end{array}$ & E & - & & - \\
\hline NOTS 2 & $15 \mathrm{~N}-03 \mathrm{E}-31$ BAA 2 & 106.4 & 20 & 15 & - & - & & - \\
\hline NOTS 3 & $14 N-02 W-23$ CCA 1 & $\begin{array}{l}119.5 \\
119.5 \\
164.9\end{array}$ & $\begin{array}{r}1 \\
1 \\
23\end{array}$ & $\begin{array}{r}1 \\
1 \\
24\end{array}$ & - & - & & - \\
\hline NOTS 4 & $10 N-01 E-11$ BBB 1 & $\begin{array}{l}101.0 \\
156.2 \\
189.0 \\
257.5\end{array}$ & $\begin{array}{l}1 \\
2 \\
1 \\
1\end{array}$ & $\begin{array}{r}1 \\
1 \\
1 \\
-\end{array}$ & $\bar{z}$ & $\begin{array}{l}- \\
-\end{array}$ & & E \\
\hline NOTS 5 & $08 N-03 E-03$ DAA 1 & $\begin{array}{r}62.0 \\
62.0 \\
131.0 \\
183.5\end{array}$ & $\begin{array}{r}1 \\
1 \\
<1 \\
1\end{array}$ & $\begin{array}{l}1 \\
1 \\
1 \\
1\end{array}$ & E & - & & E \\
\hline NOTS 6 & $14 N-03 W-07$ DAA 2 & $\begin{array}{l}106.2 \\
141.0 \\
180.8 \\
180.8 \\
222.8 \\
276.2 \\
296.2 \\
327.1 \\
475.1\end{array}$ & $\begin{array}{r}1 \\
1 \\
2 \\
2 \\
2 \\
3 \\
1 \\
3 \\
65\end{array}$ & $\begin{array}{r}1 \\
1 \\
2 \\
2 \\
2 \\
3 \\
2 \\
4 \\
65\end{array}$ & $\begin{array}{l}- \\
- \\
- \\
- \\
3^{*} \\
2^{*} \\
3^{*} \\
72^{* *}\end{array}$ & $\begin{array}{r}- \\
- \\
= \\
2 . \overline{5} \\
1.7 \\
2.9 \\
70\end{array}$ & - & $\begin{array}{c}\bar{Z} \\
\bar{Z} \\
\bar{Z} \\
0.32^{*} \\
0.03^{*} \\
0.11^{*} \\
1.7^{*}\end{array}$ \\
\hline NOTS 7 & $09 N-02 W-29$ DCA 5 & 262.7 & 33 & 21 & - & - & & - \\
\hline NOTS $7 \mathrm{~A}$ & $09 N-02 W-29$ DCA 6 & $\begin{array}{l}330.1 \\
407.5 \\
480.0 \\
480.0\end{array}$ & $\begin{array}{r}51 \\
20 \\
9 \\
8\end{array}$ & $\begin{array}{r}57 \\
20 \\
7 \\
6\end{array}$ & $\begin{array}{l}57^{*} \\
17^{*} \\
10^{*} \\
-\end{array}$ & $\begin{array}{l}57 \\
17 \\
10 \\
-\end{array}$ & * & $\begin{array}{l}0.06^{*} \\
0.16^{*} \\
0.31^{*} \\
-\end{array}$ \\
\hline
\end{tabular}


Table 10.-Concentrations of chromizm in water from NOTS test holes

[Sampling depth, center of sampling interval below land surface; ICP, analyzed using inductively coupled plasma spectrophotometry; DCP, analyzed using direct coupled plasma spectrophometry; ug/L. micrograms per liter; - indicates no data are available; <, indicates concentration is less than the specified value. All samples analyzed by the National Water Quality Laboratory of the U.S. Geological Survey]

\begin{tabular}{|c|c|c|c|c|c|c|}
\hline $\begin{array}{c}\text { Test-hole } \\
\text { name }\end{array}$ & $\begin{array}{l}\text { Local } \\
\text { identifier }\end{array}$ & $\begin{array}{l}\text { Sampling } \\
\text { depth } \\
\text { (feet) }\end{array}$ & $\begin{array}{l}\text { Chrom i um, } \\
\text { dissolved, } \\
\text { ICP } \\
(u g / L \\
\text { os } C r \text { ) }\end{array}$ & $\begin{array}{c}\text { Chrom i um, } \\
\text { di ssol ved, } \\
\text { DCP } \\
(u g / L \\
\text { as } C r \text { ) }\end{array}$ & $\begin{array}{l}\text { Chromium } \\
\text { hexavalent, } \\
\text { dissolved } \\
\text { (ug/L } \\
\text { as Cr) }\end{array}$ & $\begin{array}{c}\text { Chromium, } \\
\text { totol } \\
\text { (ug/L } \\
\text { as } C r)\end{array}$ \\
\hline
\end{tabular}

\begin{tabular}{|c|c|c|c|c|c|c|c|}
\hline NOTS $1 \mathrm{~A}$ & $16 N-02 W-21$ & BAA & $\begin{array}{l}3 \quad 176.0 \\
229.0\end{array}$ & $\begin{array}{l}80 \\
60\end{array}$ & $\begin{array}{l}90 \\
60\end{array}$ & $\begin{array}{r}110 \\
58\end{array}$ & $\begin{array}{l}82 \\
74\end{array}$ \\
\hline NOTS 2 & $15 N-03 E-31$ & BAA & 2106.4 & $<5$ & $<1$ & $<1$ & 9 \\
\hline NOTS 3 & $14 N-02 W-23$ & $\mathrm{CCA}$ & $\begin{array}{ll}1 \quad 119.5 \\
119.5 \\
164.9\end{array}$ & $\begin{array}{r}<5 \\
<5 \\
5\end{array}$ & $\begin{array}{l}1 \\
1 \\
4\end{array}$ & $\begin{array}{l}1 \\
2 \\
5\end{array}$ & $\begin{array}{l}<1 \\
<1 \\
14\end{array}$ \\
\hline NOTS 4 & $10 \mathrm{~N}-01 \mathrm{E}-11$ & BBB & $\begin{array}{l}101.0 \\
156.2 \\
189.0 \\
257.5\end{array}$ & $\begin{array}{r}<5 \\
<5 \\
<5 \\
8\end{array}$ & $\begin{array}{l}2 \\
3 \\
4 \\
7\end{array}$ & $\begin{array}{l}1 \\
2 \\
3 \\
4\end{array}$ & $\begin{array}{l}3 \\
1 \\
7 \\
5\end{array}$ \\
\hline NOTS 5 & $08 N-03 E-03$ & DAA & $\begin{array}{r}62.0 \\
62.0 \\
131.0 \\
183.5\end{array}$ & $\begin{array}{l}<5 \\
<5 \\
<1 \\
<1\end{array}$ & $\begin{array}{l}<1 \\
<1 \\
<1 \\
<1\end{array}$ & $\begin{array}{l}<1 \\
<1 \\
1 \\
<1\end{array}$ & $\begin{array}{r}<1 \\
1 \\
8 \\
4\end{array}$ \\
\hline NOTS 6 & $14 N-03 W-07$ & DAA & $2 \quad \begin{array}{r}106.2 \\
141.0 \\
180.8 \\
180.8 \\
222.8 \\
276.2 \\
296.2 \\
327.1 \\
475.1\end{array}$ & $\begin{array}{l}<5 \\
<5 \\
20 \\
20 \\
20 \\
30 \\
20 \\
20 \\
40\end{array}$ & $\begin{array}{l}z \\
z \\
z \\
z \\
-\end{array}$ & $\begin{array}{r}1 \\
1 \\
12 \\
11 \\
17 \\
26 \\
12 \\
14 \\
<1\end{array}$ & $\begin{array}{r}4 \\
4 \\
15 \\
14 \\
19 \\
29 \\
21 \\
24 \\
89\end{array}$ \\
\hline NOTS 7 & $09 N-02 W-29$ & DCA & 262.7 & $<5$ & - & - & 98 \\
\hline NOTS $7 A$ & $09 N-02 W-29$ & DCA & $\begin{array}{l}330.1 \\
407.5 \\
480.0 \\
480.0\end{array}$ & $\begin{array}{l}<5 \\
<5 \\
<5 \\
<5\end{array}$ & E & $\begin{array}{r}3 \\
<1 \\
1 \\
-\end{array}$ & $\begin{array}{r}1 \\
16 \\
28 \\
23\end{array}$ \\
\hline
\end{tabular}


Table 11.-Concentrations of selenizm in water from NoTs test holes

[Sampling depth, center of sampling interval below land surface; *, analyzed by California District Office of the U.S. Geological Survey, Water Resources Division, Sacramento California; ug/L, micrograns per liter; <, indicates concentration is less than the specified value; - indicates no data are available; tr, trace amount detected. All sanples analyzed by the National Water Quality Laboratory of the U.S.Geological Survey unless otherwise noted]

\begin{tabular}{|c|c|c|c|c|c|c|c|c|}
\hline $\begin{array}{c}\text { Test-hole } \\
\text { name }\end{array}$ & $\begin{array}{l}\text { Local } \\
\text { identifier }\end{array}$ & $\begin{array}{l}\text { Sampling } \\
\text { depth } \\
\text { (feet) }\end{array}$ & $\begin{array}{l}\text { Selenium, } \\
\text { dissolved } \\
\text { (ug/L as } S e \text { ) }\end{array}$ & $\begin{array}{l}\text { Selenium, } \\
\text { total } \\
\text { (ug/L as Se) }\end{array}$ & $\begin{array}{l}\text { Selenium, } \\
\text { dissolved } \\
\text { (ug/L as Se) }\end{array}$ & $\begin{array}{c}\text { Selenate, } \\
\mathrm{SeO}_{4}= \\
\text { dissolved } \\
\text { (ug/L as } \mathrm{Se} \text { ) }\end{array}$ & $\begin{array}{c}\text { Selenite, } \\
\mathrm{SeO}_{3}= \\
\text { dissolved } \\
\text { (ug/L as } \mathrm{Se} \text { ) }\end{array}$ & $\begin{array}{c}\text { Selenium, } \\
\text { organic, } \\
\text { dissolved } \\
\text { (ug/L as } \mathrm{Se} \text { ) }\end{array}$ \\
\hline NOTS $1 \mathrm{~A}$ & $16 N-02 W-21$ BAA 3 & $\begin{array}{l}176.0 \\
229.0\end{array}$ & $\begin{array}{r}75 \\
250\end{array}$ & $\begin{array}{r}75 \\
240\end{array}$ & $\begin{array}{r}70^{*} \\
227^{*}\end{array}$ & $\begin{array}{r}70^{*} \\
228^{*}\end{array}$ & $\begin{array}{l}0.0^{*} \\
5.0^{*}\end{array}$ & $\begin{array}{l}<0.5^{*} \\
<0.5^{*}\end{array}$ \\
\hline NOTS 2 & $15 \mathrm{~N}-03 \mathrm{E}-31$ BAA 2 & 106.4 & 13 & 12 & $11^{*}$ & $11^{*}$ & $1 . \theta^{*}$ & $<0.5^{*}$ \\
\hline NOTS 3 & $14 N-02 W-23$ CCA 1 & $\begin{array}{l}119.5 \\
119.5 \\
164.9\end{array}$ & $\begin{array}{r}<1 \\
<1 \\
1\end{array}$ & $\begin{array}{r}<1 \\
<1 \\
1\end{array}$ & E & E & E & E \\
\hline NOTS 4 & $10 \mathrm{~N}-01 \mathrm{E}-11$ BBB 1 & $\begin{array}{l}101.0 \\
156.2 \\
189.0 \\
257.5\end{array}$ & $\begin{array}{l}<1 \\
<1 \\
<1 \\
<1\end{array}$ & $\begin{array}{l}<1 \\
<1 \\
<1 \\
-\end{array}$ & E & E & E & E \\
\hline NOTS 5 & $08 N-03 E-03$ DAA 1 & $\begin{array}{r}62.0 \\
62.0 \\
131.0 \\
183.5\end{array}$ & $\begin{array}{l}16 \\
18 \\
<1 \\
<1\end{array}$ & $\begin{array}{l}18 \\
18 \\
<1 \\
<1\end{array}$ & $\begin{array}{l}17^{*} \\
17^{*} \\
-\end{array}$ & $\begin{array}{c}17^{*} \\
16^{*} \\
- \\
-\end{array}$ & $\begin{array}{l}0.0^{*} \\
0.0^{*} \\
-\end{array}$ & $\begin{array}{l}0.0^{*} \\
1.0^{*} \\
-\end{array}$ \\
\hline NOTS 6 & $14 N-03 W-07$ DAA 2 & $\begin{array}{l}106.2 \\
141.0 \\
180.8 \\
180.8 \\
222.8 \\
276.2 \\
296.2 \\
327.1 \\
475.1\end{array}$ & $\begin{array}{r}6 \\
4 \\
3 \\
3 \\
2 \\
10 \\
3 \\
11 \\
380\end{array}$ & $\begin{array}{r}6 \\
3 \\
3 \\
3 \\
1 \\
9 \\
3 \\
12 \\
390\end{array}$ & $\begin{array}{l}\bar{Z} \\
\bar{Z} \\
\overline{10} \\
\overline{11^{*}} \\
394^{*}\end{array}$ & $\begin{array}{r}\text { - } \\
\overline{-} \\
{ }^{10^{*}} \\
{ }^{11^{*}} \\
369^{*}\end{array}$ & $\begin{array}{c}\bar{Z} \\
\bar{E} \\
\overline{0.0^{*}} \\
\bar{\theta}^{0.0^{*}}\end{array}$ & $\begin{array}{l}\bar{Z} \\
\bar{Z} \\
\overline{0.0^{*}} \\
\overline{0.0^{*}} \\
\mathrm{tr}^{*}\end{array}$ \\
\hline NOTS 7 & $09 N-02 W-29$ DCA 5 & 262.7 & 11 & 12 & - & - & - & - \\
\hline NOTS 7A & $09 N-02 W-29$ DCA 6 & $\begin{array}{l}330.1 \\
407.5 \\
480.0 \\
480.0\end{array}$ & $\begin{array}{r}93 \\
19 \\
3 \\
3\end{array}$ & $\begin{array}{r}92 \\
18 \\
3 \\
3\end{array}$ & $\begin{array}{l}92^{*} \\
\frac{18^{*}}{2.5^{*}}\end{array}$ & $\begin{array}{l}90^{*} \\
18^{*} \\
2.5^{*}\end{array}$ & $\begin{array}{l}2.0^{*} \\
0.0^{*} \\
<0.5^{*}\end{array}$ & $\begin{array}{l}0.0^{*} \\
<0.5^{*} \\
<0.5^{*}\end{array}$ \\
\hline
\end{tabular}


Table 12.-Concentrations of selected radionaclides in water from NoTS test holes

[Sampling depth, center of sampling interval below land surface; $p C i / L$, picocuries per Iiter; Th-230, thorium-230; ug/L, micrograms per liter; U-nat, uranium natural; - indicates no data are available; <, indicates concentration is less than the specified value; Cs-137, cesium-137; Sr/Y-90, strontium-90/yttrium-90; U, uranium. All samples analyzed by the National Water Quality Laboratory of the U.S. Geological Survey]

\begin{tabular}{|c|c|c|c|c|c|c|c|c|c|c|c|c|c|c|c|}
\hline $\begin{array}{c}\text { Test-hole } \\
\text { name }\end{array}$ & \multicolumn{2}{|l|}{$\begin{array}{c}\text { Local } \\
\text { identifier }\end{array}$} & \multirow{2}{*}{$\begin{array}{l}\text { Sampling } \\
\text { depth } \\
\text { (feet) }\end{array}$} & \multicolumn{3}{|c|}{$\begin{array}{c}\text { Gross alpha, } \\
\text { dissolved } \\
\text { (pCi/L as } \\
\text { Th-230) }\end{array}$} & \multicolumn{3}{|c|}{$\begin{array}{c}\text { Gross alpha, } \\
\text { suspended } \\
\text { (pCi/L as } \\
\text { Th-230) }\end{array}$} & \multicolumn{3}{|c|}{$\begin{array}{c}\text { Gross alpha, } \\
\text { dissolved } \\
\text { (ug/L as } \\
\text { U-nat) }\end{array}$} & \multicolumn{3}{|c|}{$\begin{array}{c}\text { Gross al pha, } \\
\text { suspended } \\
\text { (ug/L as } \\
\text { U-nat) }\end{array}$} \\
\hline NOTS $1 \mathrm{~A}$ & $16 \mathrm{~N}-02 \mathrm{~W}-21 \mathrm{BAA}$ & 3 & & $\begin{array}{r}72 \\
160\end{array}$ & $\begin{array}{l} \pm \\
\pm\end{array}$ & 17.2 & $\begin{array}{r}<0.4 \\
9.4\end{array}$ & $\begin{array}{l} \pm \\
\pm\end{array}$ & $\begin{array}{l}0.20 \\
3.7\end{array}$ & $\begin{array}{r}65 \\
150\end{array}$ & $\begin{array}{l} \pm \\
\pm\end{array}$ & $20^{9.0}$ & $\begin{array}{l}<0.4 \\
13\end{array}$ & $\begin{array}{l} \pm \\
\pm\end{array}$ & $\begin{array}{l}0.35 \\
5.2\end{array}$ \\
\hline NOTS 2 & $15 \mathrm{~N}-03 \mathrm{E}-31 \mathrm{BAA}$ & 2 & 106.4 & 43 & \pm & 6.1 & 5.1 & \pm & 2.5 & 39 & \pm & 5.9 & 5.7 & \pm & 2.8 \\
\hline NOTS 3 & $14 \mathrm{~N}-02 \mathrm{~W}-23 \mathrm{CCA}$ & 1 & $\begin{array}{l}119.5 \\
119.5 \\
164.9\end{array}$ & $\begin{array}{r}1.9 \\
2.0 \\
52\end{array}$ & $\begin{array}{l} \pm \\
\pm \\
\pm\end{array}$ & $\begin{array}{l}0.82 \\
0.81 \\
7.5\end{array}$ & $\begin{array}{r}<0.4 \\
<0.4 \\
5.9\end{array}$ & $\begin{array}{l} \pm \\
\pm \\
\pm\end{array}$ & $\begin{array}{l}0.41 \\
0.30 \\
3.0\end{array}$ & $\begin{array}{r}3.8 \\
4.0 \\
52\end{array}$ & $\begin{array}{l} \pm \\
\pm \\
\pm\end{array}$ & $\begin{array}{l}1.6 \\
1.6 \\
7.8\end{array}$ & $\begin{array}{r}<0.4 \\
<0.4 \\
7.1\end{array}$ & $\begin{array}{l} \pm \\
\pm \\
\pm\end{array}$ & $\begin{array}{l}0.39 \\
0.35 \\
3.6\end{array}$ \\
\hline NOTS 4 & $10 N-01 E-11$ BBB & 1 & $\begin{array}{l}101.0 \\
156.2 \\
189.0 \\
257.5\end{array}$ & $\begin{array}{r}1.5 \\
4.5 \\
7.8 \\
12\end{array}$ & $\begin{array}{l} \pm \\
\pm \\
\pm \\
\pm\end{array}$ & $\begin{array}{l}0.85 \\
1.5 \\
3.1 \\
2.3\end{array}$ & $\begin{array}{l}<0.4 \\
0.5 \\
1.4 \\
1.0\end{array}$ & $\begin{array}{l} \pm \\
\pm \\
\pm \\
\pm\end{array}$ & $\begin{array}{l}0.33 \\
0.53 \\
0.86 \\
0.82\end{array}$ & $\begin{array}{r}1.5 \\
4.3 \\
7.4 \\
12\end{array}$ & $\begin{array}{l} \pm \\
\pm \\
\pm \\
\pm\end{array}$ & $\begin{array}{l}0.83 \\
1.4 \\
3.0 \\
2.5\end{array}$ & $\begin{array}{r}<0.4 \\
0.6 \\
1.3 \\
0.8\end{array}$ & $\begin{array}{l} \pm \\
\pm \\
\pm \\
\pm\end{array}$ & $\begin{array}{l}0.54 \\
0.55 \\
0.78 \\
0.64\end{array}$ \\
\hline NOTS 5 & $08 \mathrm{~N}-03 \mathrm{E}-03 \mathrm{DAA}$ & 1 & $\begin{array}{r}62.0 \\
62.0 \\
131.0 \\
183.5\end{array}$ & $\begin{array}{l}46 \\
62 \\
12 \\
6.1\end{array}$ & $\begin{array}{l} \pm \\
\pm \\
\pm \\
\pm\end{array}$ & $\begin{array}{l}7.7 \\
8.4 \\
2.8 \\
1.8\end{array}$ & $\begin{array}{c}<0.4 \\
<0.4 \\
19 \\
3.2\end{array}$ & $\begin{array}{l} \pm \\
\pm \\
\pm \\
\pm\end{array}$ & $\begin{array}{l}0.29 \\
0.27 \\
4.8 \\
1.3\end{array}$ & $\begin{array}{l}45 \\
56 \\
11 \\
5.9\end{array}$ & $\begin{array}{l} \pm \\
\pm \\
\pm \\
\pm\end{array}$ & $\begin{array}{l}6.6 \\
8.2 \\
2.7 \\
1.8\end{array}$ & $\begin{array}{l}0.4 \\
<0.4 \\
17 \\
2.5\end{array}$ & $\begin{array}{l} \pm \\
\pm \\
\pm \\
\pm\end{array}$ & $\begin{array}{l}0.47 \\
0.44 \\
4.2 \\
1.0\end{array}$ \\
\hline NOTS 6 & $14 N-03 W-07$ DAA & 2 & $\begin{array}{l}106.2 \\
141.0 \\
180.8 \\
180.8 \\
222.8 \\
276.2 \\
296.2 \\
327.1 \\
475.1\end{array}$ & $\begin{array}{c}6.7 \\
7.1 \\
5.8 \\
11 \\
11 \\
19 \\
16 \\
16 \\
240\end{array}$ & $\begin{array}{l} \pm \\
\pm \\
\pm \\
\pm \\
\pm \\
\pm \\
\pm \\
\pm \\
\pm\end{array}$ & $\begin{array}{l}1.5 \\
1.5 \\
1.4 \\
2.3 \\
1.9 \\
2.8 \\
2.5 \\
2.6 \\
26\end{array}$ & $\begin{array}{r}<0.4 \\
<0.4 \\
<0.4 \\
<0.4 \\
<0.4 \\
<0.4 \\
<0.4 \\
0.5 \\
3.7\end{array}$ & $\begin{array}{l} \pm \\
\pm \\
\pm \\
\pm \\
\pm \\
\pm \\
\pm \\
\pm \\
\pm\end{array}$ & $\begin{array}{l}0.21 \\
0.23 \\
0.30 \\
0.27 \\
0.21 \\
0.41 \\
0.35 \\
0.51 \\
2.5\end{array}$ & $\begin{array}{c}9.9 \\
11 \\
8.2 \\
17 \\
16 \\
27 \\
23 \\
23 \\
350\end{array}$ & $\begin{array}{l} \pm \\
\pm \\
\pm \\
\pm \\
\pm \\
\pm \\
\pm \\
\pm \\
\pm\end{array}$ & $\begin{array}{l}2.1 \\
2.2 \\
1.9 \\
3.2 \\
2.9 \\
4.0 \\
3.5 \\
3.7 \\
33\end{array}$ & $\begin{array}{r}<0.4 \\
<0.4 \\
<0.4 \\
<0.4 \\
<0.4 \\
0.5 \\
0.6 \\
0.6 \\
2.8\end{array}$ & $\begin{array}{l} \pm \\
\pm \\
\pm \\
\pm \\
\pm \\
\pm \\
\pm \\
\pm \\
\pm\end{array}$ & $\begin{array}{l}0.36 \\
0.37 \\
0.55 \\
0.47 \\
0.40 \\
0.63 \\
0.55 \\
0.59 \\
1.9\end{array}$ \\
\hline NOTS 7 & $09 N-02 W-29 \mathrm{DCA}$ & 5 & 262.7 & 18 & \pm & 4.8 & 150 & \pm & 62 & 26 & \pm & 7.0 & 180 & \pm & 76 \\
\hline NOTS $7 \mathrm{~A}$ & $09 N-02 W-29 D C A$ & 6 & $\begin{array}{l}330.1 \\
407.5 \\
480.0 \\
480.0\end{array}$ & $\begin{array}{l}40 \\
5.1 \\
4.0 \\
13\end{array}$ & $\begin{array}{l} \pm \\
\pm \\
\pm \\
\pm\end{array}$ & $\begin{array}{l}4.5 \\
0.92 \\
0.83 \\
3.4\end{array}$ & $\begin{array}{l}3.5 \\
6.4 \\
8.8 \\
6.9\end{array}$ & $\begin{array}{l} \pm \\
\pm \\
\pm \\
\pm\end{array}$ & $\begin{array}{l}0.72 \\
1.5 \\
2.0 \\
1.5\end{array}$ & $\begin{array}{c}37 \\
4.7 \\
3.7 \\
12\end{array}$ & $\begin{array}{l} \pm \\
\pm \\
\pm \\
\pm\end{array}$ & $\begin{array}{l}4.1 \\
0.84 \\
0.75 \\
3.1\end{array}$ & $\begin{array}{l}3.8 \\
7.2 \\
7.9 \\
6.3\end{array}$ & $\begin{array}{l} \pm \\
\pm \\
\pm \\
\pm\end{array}$ & $\begin{array}{l}0.79 \\
1.7 \\
1.7 \\
1.3\end{array}$ \\
\hline
\end{tabular}


Table 12. -Concentrations of selected radionaulides in water from NOTS test holes-Cont inued

\begin{tabular}{|c|c|c|c|c|c|c|c|c|c|c|c|c|c|c|}
\hline $\begin{array}{c}\text { Test-hole } \\
\text { name }\end{array}$ & $\begin{array}{l}\text { Local } \\
\text { identifier }\end{array}$ & \multirow{2}{*}{$\begin{array}{l}\text { Sampling } \\
\text { depth } \\
\text { (feet) }\end{array}$} & \multicolumn{3}{|c|}{$\begin{array}{c}\text { Gross beta, } \\
\text { dissolved } \\
(\mathrm{pCi} / \mathrm{L} \text { as } \\
\mathrm{Cs}-137)\end{array}$} & \multicolumn{3}{|c|}{$\begin{array}{c}\text { Gross beta, } \\
\text { suspended } \\
(\mathrm{pCi} / \mathrm{L} \text { as } \\
\mathrm{Cs-137)}\end{array}$} & \multicolumn{3}{|c|}{$\begin{array}{c}\text { Gross beta, } \\
\text { dissolved } \\
(\mathrm{pCi} / \mathrm{L} \\
\mathrm{Sr} / \mathrm{Y}-90)\end{array}$} & \multicolumn{3}{|c|}{$\begin{array}{c}\text { Gross beta, } \\
\text { suspended } \\
(\mathrm{pCi} / \mathrm{L} \\
\mathrm{Sr} / \mathrm{Y}-90)\end{array}$} \\
\hline NOTS $1 \mathrm{~A}$ & $16 N-02 W-21$ BAA & & $\begin{array}{l}21 \\
62\end{array}$ & $\begin{array}{l} \pm \\
\pm\end{array}$ & $\begin{array}{l}3.2 \\
7.7\end{array}$ & $\begin{array}{l}<0.4 \\
36\end{array}$ & $\begin{array}{l} \pm \\
\pm\end{array}$ & $\begin{array}{l}0.45 \\
4.5\end{array}$ & $\begin{array}{l}16 \\
44\end{array}$ & $\begin{array}{l} \pm \\
\pm\end{array}$ & $\begin{array}{l}2.4 \\
5.5\end{array}$ & $\begin{array}{l}<0.4 \\
31\end{array}$ & $\begin{array}{l} \pm \\
\pm\end{array}$ & $\begin{array}{l}0.47 \\
3.9\end{array}$ \\
\hline NOTS 2 & $15 \mathrm{~N}-03 \mathrm{E}-31 \mathrm{BAA}$ & 106.4 & 19 & \pm & 3.0 & 3.4 & \pm & 0.97 & 13 & \pm & 2.2 & 3.0 & \pm & 0.85 \\
\hline NOTS 3 & $14 N-02 W-23 \mathrm{CCA}$ & $\begin{array}{l}119.5 \\
119.5 \\
164.9\end{array}$ & $\begin{array}{r}2.7 \\
2.2 \\
16\end{array}$ & $\begin{array}{l} \pm \\
\pm \\
\pm\end{array}$ & $\begin{array}{l}1.1 \\
1.0 \\
2.7\end{array}$ & $\begin{array}{r}<0.4 \\
<0.4 \\
9.1\end{array}$ & $\begin{array}{l} \pm \\
\pm \\
\pm\end{array}$ & $\begin{array}{l}0.48 \\
0.46 \\
1.6\end{array}$ & $\begin{array}{r}2.0 \\
1.6 \\
12\end{array}$ & $\begin{array}{l} \pm \\
\pm \\
\pm\end{array}$ & $\begin{array}{l}0.82 \\
0.77 \\
2.0\end{array}$ & $\begin{array}{r}<0.4 \\
<0.4 \\
8.0\end{array}$ & $\begin{array}{l} \pm \\
\pm \\
\pm\end{array}$ & $\begin{array}{l}0.48 \\
0.45 \\
1.4\end{array}$ \\
\hline NOTS 4 & $10 N-01 E-11 B B B$ & $\begin{array}{l}101.0 \\
156.2 \\
189.0 \\
257.5\end{array}$ & $\begin{array}{l}1.6 \\
3.2 \\
3.8 \\
6.7\end{array}$ & $\begin{array}{l} \pm \\
\pm \\
\pm \\
\pm\end{array}$ & $\begin{array}{l}0.85 \\
1.1 \\
1.3 \\
1.5\end{array}$ & $\begin{array}{r}<0.4 \\
1.1 \\
1.4 \\
2.0\end{array}$ & $\begin{array}{l} \pm \\
\pm \\
\pm \\
\pm\end{array}$ & $\begin{array}{l}0.45 \\
0.59 \\
0.64 \\
0.73\end{array}$ & $\begin{array}{l}1.2 \\
2.4 \\
2.7 \\
5.1\end{array}$ & $\begin{array}{l} \pm \\
\pm \\
\pm \\
\pm\end{array}$ & $\begin{array}{l}0.64 \\
0.82 \\
0.82 \\
1.2\end{array}$ & $\begin{array}{r}<0.4 \\
1.1 \\
1.4 \\
1.9\end{array}$ & $\begin{array}{l} \pm \\
\pm \\
\pm \\
\pm\end{array}$ & $\begin{array}{l}0.44 \\
0.58 \\
0.65 \\
0.70\end{array}$ \\
\hline NOTS 5 & $08 N-03 E-03$ DAA & $\begin{array}{r}62.0 \\
62.0 \\
131.0 \\
183.5\end{array}$ & $\begin{array}{l}25 \\
21 \\
15 \\
15\end{array}$ & $\begin{array}{l} \pm \\
\pm \\
\pm \\
\pm\end{array}$ & $\begin{array}{c}4.0 \\
3.5 \\
13 \\
9.7\end{array}$ & $\begin{array}{l}1.8 \\
1.2 \\
7.0 \\
3.0\end{array}$ & $\begin{array}{l} \pm \\
\pm \\
\pm \\
\pm\end{array}$ & $\begin{array}{l}0.68 \\
0.60 \\
1.3 \\
0.84\end{array}$ & $\begin{array}{l}17 \\
15 \\
9.3 \\
9.9\end{array}$ & $\begin{array}{l} \pm \\
\pm \\
\pm \\
\pm\end{array}$ & $\begin{array}{l}2.7 \\
2.4 \\
8.3 \\
6.4\end{array}$ & $\begin{array}{l}1.9 \\
1.2 \\
6.3 \\
3.0\end{array}$ & $\begin{array}{l} \pm \\
\pm \\
\pm \\
\pm\end{array}$ & $\begin{array}{l}0.70 \\
0.59 \\
1.2 \\
0.81\end{array}$ \\
\hline NOTS 6 & $14 \mathrm{~N}-03 \mathrm{~W}-07$ DAA & $\begin{array}{l}106.2 \\
141.0 \\
180.8 \\
180.8 \\
222.8 \\
276.2 \\
296.2 \\
327.1 \\
475.1\end{array}$ & $\begin{array}{r}3.6 \\
3.3 \\
4.4 \\
5.6 \\
6.7 \\
5.5 \\
4.5 \\
5.2 \\
51\end{array}$ & $\begin{array}{l} \pm \\
\pm \\
\pm \\
\pm \\
\pm \\
\pm \\
\pm \\
\pm \\
\pm\end{array}$ & $\begin{array}{l}1.2 \\
1.1 \\
1.3 \\
1.4 \\
1.6 \\
1.4 \\
1.3 \\
1.4 \\
6.7\end{array}$ & $\begin{array}{r}<0.4 \\
<0.4 \\
<0.4 \\
<0.4 \\
<0.4 \\
4.3 \\
2.5 \\
3.5 \\
90\end{array}$ & $\begin{array}{l} \pm \\
\pm \\
\pm \\
\pm \\
\pm \\
\pm \\
\pm \\
\pm \\
\pm\end{array}$ & $\begin{array}{l}0.43 \\
0.38 \\
0.53 \\
0.46 \\
0.43 \\
0.96 \\
0.75 \\
0.88 \\
11\end{array}$ & $\begin{array}{l}2.6 \\
2.5 \\
3.3 \\
4.1 \\
5.0 \\
4.2 \\
3.4 \\
3.9 \\
35\end{array}$ & $\begin{array}{l} \pm \\
\pm \\
\pm \\
\pm \\
\pm \\
\pm \\
\pm \\
\pm \\
\pm\end{array}$ & $\begin{array}{l}0.86 \\
0.82 \\
0.96 \\
1.1 \\
1.2 \\
1.0 \\
0.97 \\
1.0 \\
4.6\end{array}$ & $\begin{array}{r}<0.4 \\
<0.4 \\
<0.4 \\
<0.4 \\
<0.4 \\
4.2 \\
2.5 \\
3.4 \\
83\end{array}$ & $\begin{array}{l} \pm \\
\pm \\
\pm \\
\pm \\
\pm \\
\pm \\
\pm \\
\pm \\
\pm\end{array}$ & $\begin{array}{l}0.44 \\
0.39 \\
0.52 \\
0.48 \\
0.43 \\
0.94 \\
0.74 \\
0.86 \\
9.6\end{array}$ \\
\hline NOTS 7 & $09 N-02 W-29 D C A$ & 262.7 & 7.5 & \pm & 1.7 & 120 & \pm & 26 & 5.7 & \pm & 1.3 & 100 & \pm & 22 \\
\hline NOTS $7 A$ & $09 N-02 W-29$ DCA & $\begin{array}{l}330.1 \\
407.5 \\
480.0 \\
480.0\end{array}$ & $\begin{array}{l}10 \\
3.7 \\
9.3 \\
12\end{array}$ & $\begin{array}{l} \pm \\
\pm \\
\pm \\
\pm\end{array}$ & $\begin{array}{l}1.4 \\
0.94 \\
1.5 \\
3.0\end{array}$ & $\begin{array}{c}17 \\
9.3 \\
13 \\
8.5\end{array}$ & $\begin{array}{l} \pm \\
\pm \\
\pm \\
\pm\end{array}$ & $\begin{array}{l}2.0 \\
1.4 \\
1.9 \\
1.4\end{array}$ & $\begin{array}{l}9.0 \\
3.3 \\
8.0 \\
9.6\end{array}$ & $\begin{array}{l} \pm \\
\pm \\
\pm \\
\pm\end{array}$ & $\begin{array}{l}1.3 \\
0.83 \\
1.2 \\
2.4\end{array}$ & $\begin{array}{l}17 \\
7.4 \\
10 \\
6.8\end{array}$ & $\begin{array}{l} \pm \\
\pm \\
\pm \\
\pm\end{array}$ & $\begin{array}{l}2.0 \\
1.1 \\
1.5 \\
2.4\end{array}$ \\
\hline
\end{tabular}


Table 12. - Concentrations of selected radionaulides in water from NoTS test holes-Cont inued

\begin{tabular}{|c|c|c|c|c|c|c|c|c|c|c|c|c|c|}
\hline $\begin{array}{l}\text { Test-hole } \\
\text { name }\end{array}$ & $\begin{array}{c}\text { Local } \\
\text { identifier }\end{array}$ & \multirow{2}{*}{$\begin{array}{c}\begin{array}{c}\text { Sampl ing } \\
\text { depth } \\
\text { (feet) }\end{array} \\
\begin{array}{l}176.0 \\
229.0\end{array}\end{array}$} & \multicolumn{2}{|c|}{$\begin{array}{l}\text { Radi um-226, } \\
\text { dissolved } \\
(\mathrm{pC} \mathrm{i} / \mathrm{L})\end{array}$} & \multicolumn{3}{|c|}{$\begin{array}{l}\text { Rad i um-228, } \\
\text { di ssol ved } \\
(\mathrm{pC} \mathrm{i} / \mathrm{L})\end{array}$} & \multicolumn{3}{|c|}{$\begin{array}{c}\text { Radon-222, } \\
\text { total } \\
(\mathrm{pCi} / \mathrm{L})\end{array}$} & \multicolumn{3}{|c|}{$\begin{array}{l}\text { Tritium, } \\
\text { total } \\
(\mathrm{pCi} / L)\end{array}$} \\
\hline NOTS $1 \mathrm{~A}$ & $16 N-02 W-21 B A A$ & & $\begin{array}{l}0.06 \\
0.04\end{array}$ & $\begin{array}{l} \pm 0.013 \\
\pm \quad 0.012\end{array}$ & $\begin{array}{l}<1.0 \\
<1.0\end{array}$ & $\begin{array}{l} \pm \\
\pm\end{array}$ & $\begin{array}{l}0.73 \\
0.36\end{array}$ & $\begin{array}{l}<80 \\
118\end{array}$ & $\begin{array}{l} \pm \\
\pm\end{array}$ & $\begin{array}{l}51 \\
36\end{array}$ & - & & - \\
\hline NOTS 2 & $15 N-03 E-31$ BAA & 106.4 & 0.03 & \pm 0.013 & $<1.0$ & \pm & 0.97 & 200 & \pm & 40 & - & & - \\
\hline NOTS 3 & $14 \mathrm{~N}-02 \mathrm{~W}-23 \mathrm{CCA}$ & $\begin{array}{l}119.5 \\
119.5 \\
164.9\end{array}$ & $\begin{array}{l}0.32 \\
0.34 \\
0.05\end{array}$ & 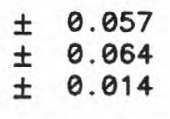 & $\begin{array}{l}<1.0 \\
<1.0 \\
<1.0\end{array}$ & $\begin{array}{l} \pm \\
\pm \\
\pm\end{array}$ & $\begin{array}{l}0.68 \\
0.67 \\
0.62\end{array}$ & $\begin{array}{l}<80 \\
<80 \\
290\end{array}$ & $\begin{array}{l} \pm \\
\pm \\
\pm\end{array}$ & $\begin{array}{l}38 \\
36 \\
47\end{array}$ & E & & E \\
\hline NOTS 4 & $10 \mathrm{~N}-01 \mathrm{E}-11 \mathrm{BBB}$ & $\begin{array}{l}101.0 \\
156.2 \\
189.0 \\
257.5\end{array}$ & $\begin{array}{l}0.11 \\
0.29 \\
0.52 \\
0.31\end{array}$ & $\begin{array}{ll} \pm & 0.023 \\
\pm & 0.052 \\
\pm & 0.088 \\
\pm & 0.056\end{array}$ & $\begin{array}{r}<1.0 \\
1.3 \\
<1.0 \\
1.5\end{array}$ & $\begin{array}{l} \pm \\
\pm \\
\pm \\
\pm\end{array}$ & $\begin{array}{l}0.46 \\
0.71 \\
0.73 \\
0.62\end{array}$ & $\begin{array}{r}<80 \\
<80 \\
430 \\
93\end{array}$ & $\begin{array}{l} \pm \\
\pm \\
\pm \\
\pm\end{array}$ & $\begin{array}{l}36 \\
35 \\
33 \\
42\end{array}$ & $\overline{-}$ & & E \\
\hline NOTS 5 & $08 \mathrm{~N}-03 \mathrm{E}-03 \mathrm{DAA}$ & $\begin{array}{r}62.0 \\
62.0 \\
131.0 \\
183.5\end{array}$ & $\begin{array}{l}0.56 \\
0.50 \\
1.1 \\
0.90\end{array}$ & $\begin{array}{ll} \pm & 0.093 \\
\pm & 0.097 \\
\pm & 0.189 \\
\pm & 0.147\end{array}$ & $\begin{array}{l}1.3 \\
1.1 \\
1.2 \\
2.5\end{array}$ & $\begin{array}{l} \pm \\
\pm \\
\pm \\
\pm\end{array}$ & $\begin{array}{l}0.73 \\
0.73 \\
0.76 \\
0.90\end{array}$ & $\begin{array}{r}580 \\
490 \\
1,300 \\
<80\end{array}$ & $\begin{array}{l} \pm \\
\pm \\
\pm \\
\pm\end{array}$ & $\begin{array}{l}39 \\
39 \\
42 \\
51\end{array}$ & E & & $\overline{-}$ \\
\hline NOTS 6 & $14 N-03 W-07$ DAA & $\begin{array}{l}106.2 \\
141.0 \\
180.8 \\
180.8 \\
222.8 \\
276.2 \\
296.2 \\
327.1 \\
475.1\end{array}$ & $\begin{array}{l}0.28 \\
0.26 \\
0.24 \\
0.23 \\
0.31 \\
0.22 \\
0.20 \\
0.18 \\
0.08\end{array}$ & $\begin{array}{ll} \pm & 0.055 \\
\pm & 0.045 \\
\pm & 0.043 \\
\pm & 0.043 \\
\pm & 0.060 \\
\pm & 0.039 \\
\pm & 0.036 \\
\pm & 0.033 \\
\pm & 0.017\end{array}$ & $\begin{array}{l}<1.0 \\
<1.0 \\
<1.0 \\
<1.0 \\
<1.0 \\
<1.0 \\
<1.0 \\
<1.0 \\
<1.0\end{array}$ & $\begin{array}{l} \pm \\
\pm \\
\pm \\
\pm \\
\pm \\
\pm \\
\pm \\
\pm \\
\pm\end{array}$ & $\begin{array}{l}0.46 \\
0.40 \\
0.57 \\
0.53 \\
0.46 \\
0.40 \\
0.37 \\
0.45 \\
0.73\end{array}$ & $\begin{array}{l}200 \\
300 \\
350 \\
360 \\
320 \\
260 \\
520 \\
330 \\
180\end{array}$ & $\begin{array}{l} \pm \\
\pm \\
\pm \\
\pm \\
\pm \\
\pm \\
\pm \\
\pm \\
\pm\end{array}$ & $\begin{array}{l}33 \\
31 \\
39 \\
35 \\
47 \\
39 \\
40 \\
53 \\
43\end{array}$ & $\begin{array}{l}z \\
z \\
z \\
z \\
z\end{array}$ & & $\begin{array}{l}- \\
z \\
z \\
z \\
-\end{array}$ \\
\hline NOTS 7 & $09 N-02 W-29 D C A$ & 262.7 & - & - & - & & - & $<80$ & \pm & 43 & - & & - \\
\hline NOTS $7 \mathrm{~A}$ & $09 N-02 W-29 D C A$ & $\begin{array}{l}330.1 \\
407.5 \\
480.0 \\
480.0\end{array}$ & $\begin{array}{r}0.08 \\
0.08 \\
0.06 \\
-\end{array}$ & $\begin{array}{rr} \pm & 0.017 \\
\pm & 0.017 \\
\pm & 0.018 \\
& -\end{array}$ & $\begin{array}{r}<1.0 \\
<1.0 \\
<1.0 \\
\end{array}$ & $\begin{array}{l} \pm \\
\pm \\
\pm\end{array}$ & $\begin{array}{c}0.64 \\
0.92 \\
0.31 \\
-\end{array}$ & $\begin{array}{l}<80 \\
<80 \\
<80 \\
<80\end{array}$ & $\begin{array}{l} \pm \\
\pm \\
\pm \\
\pm\end{array}$ & $\begin{array}{l}40 \\
26 \\
26 \\
26\end{array}$ & $\begin{array}{l}6.1 \\
1.2 \\
4.0 \\
3.8\end{array}$ & $\begin{array}{l} \pm \\
\pm \\
\pm \\
\pm\end{array}$ & $\begin{array}{l}0.57 \\
0.64 \\
0.58 \\
0.58\end{array}$ \\
\hline
\end{tabular}


Table 12. - Concentrations of selected radionaulides in water from NoTS test holes-Cont inued

\begin{tabular}{|c|c|c|c|c|c|c|c|c|c|c|c|c|c|c|}
\hline $\begin{array}{c}\text { Test-hole } \\
\text { name }\end{array}$ & $\begin{array}{c}\text { Local } \\
\text { identifier }\end{array}$ & \multirow{2}{*}{$\begin{array}{c}\begin{array}{c}\text { Sampling } \\
\text { depth } \\
\text { (feet) }\end{array} \\
\\
176.0 \\
229.0\end{array}$} & \multicolumn{3}{|c|}{$\begin{array}{l}\text { Uran i um-234, } \\
\text { dissolved } \\
(\mathrm{pCi} / \mathrm{L})\end{array}$} & \multicolumn{3}{|c|}{$\begin{array}{l}\text { Urani um-235, } \\
\text { dissolved } \\
(\mathrm{pCi} / \mathrm{L})\end{array}$} & \multicolumn{3}{|c|}{$\begin{array}{l}\text { Urani um-238, } \\
\text { dissolved } \\
(\mathrm{pCi} / \mathrm{L})\end{array}$} & \multicolumn{3}{|c|}{$\begin{array}{c}\text { Uranium natural. } \\
\text { dissolved } \\
\text { (ug/L as } U)\end{array}$} \\
\hline NOTS $1 \mathrm{~A}$ & $16 \mathrm{~N}-02 \mathrm{~W}-21 \mathrm{BAA} 3$ & & $\begin{array}{l}32 \\
44\end{array}$ & $\begin{array}{l} \pm \\
\pm\end{array}$ & $\begin{array}{l}2.4 \\
4.6\end{array}$ & $\begin{array}{l}0.8 \\
1.5\end{array}$ & $\begin{array}{l} \pm \\
\pm\end{array}$ & $\begin{array}{l}0.26 \\
0.38\end{array}$ & $\begin{array}{l}22 \\
36\end{array}$ & $\begin{array}{l} \pm \\
\pm\end{array}$ & $\begin{array}{l}3.4 \\
3.8\end{array}$ & $\begin{array}{r}66 \\
110\end{array}$ & $\begin{array}{l} \pm \\
\pm\end{array}$ & $\begin{array}{l}10 \\
12\end{array}$ \\
\hline NOTS 2 & $15 N-03 E-31$ BAA 2 & 106.4 & 23 & \pm & 2.4 & 0.6 & \pm & 0.18 & 14 & \pm & 1.5 & 40 & \pm & 4.6 \\
\hline NOTS 3 & $14 N-02 W-23 \mathrm{CCA}$ & $\begin{array}{l}119.5 \\
119.5 \\
164.9\end{array}$ & $\begin{array}{l}0.6 \\
0.8 \\
24\end{array}$ & $\begin{array}{l} \pm \\
\pm \\
\pm\end{array}$ & $\begin{array}{l}0.08 \\
0.10 \\
2.4\end{array}$ & $\begin{array}{r}<0.1 \\
<0.1 \\
0.5\end{array}$ & $\begin{array}{l} \pm \\
\pm \\
\pm\end{array}$ & $\begin{array}{l}0.01 \\
0.01 \\
0.12\end{array}$ & $\begin{array}{l}0.2 \\
0.3 \\
9.7\end{array}$ & $\begin{array}{l} \pm \\
\pm \\
\pm\end{array}$ & $\begin{array}{l}0.04 \\
0.05 \\
1.0\end{array}$ & $\begin{array}{l}0.6 \\
0.8 \\
29\end{array}$ & $\begin{array}{l} \pm \\
\pm \\
\pm\end{array}$ & $\begin{array}{l}0.13 \\
0.16 \\
3.2\end{array}$ \\
\hline NOTS 4 & $10 N-01 E-11$ BBB & $\begin{array}{l}101.0 \\
156.2 \\
189.0 \\
257.5\end{array}$ & $\begin{array}{l}0.6 \\
1.2 \\
2.3 \\
6.1\end{array}$ & $\begin{array}{l} \pm \\
\pm \\
\pm \\
\pm\end{array}$ & $\begin{array}{l}0.09 \\
0.16 \\
0.27 \\
0.63\end{array}$ & $\begin{array}{l}<0.1 \\
<0.1 \\
<0.1 \\
<0.1\end{array}$ & $\begin{array}{l} \pm \\
\pm \\
\pm \\
\pm\end{array}$ & $\begin{array}{l}0.01 \\
0.01 \\
0.01 \\
0.02\end{array}$ & $\begin{array}{l}0.2 \\
0.3 \\
0.3 \\
0.8\end{array}$ & $\begin{array}{l} \pm \\
\pm \\
\pm \\
\pm\end{array}$ & $\begin{array}{l}0.04 \\
0.06 \\
0.07 \\
0.11\end{array}$ & $\begin{array}{l}0.6 \\
0.9 \\
1.0 \\
2.3\end{array}$ & $\begin{array}{l} \pm \\
\pm \\
\pm \\
\pm\end{array}$ & $\begin{array}{l}0.14 \\
0.18 \\
0.20 \\
0.34\end{array}$ \\
\hline NOTS 5 & $08 \mathrm{~N}-03 \mathrm{E}-03$ DAA & $\begin{array}{r}62.0 \\
62.0 \\
131.0 \\
183.5\end{array}$ & $\begin{array}{c}18 \\
18 \\
9.3 \\
7.6\end{array}$ & $\begin{array}{l} \pm \\
\pm \\
\pm \\
\pm\end{array}$ & $\begin{array}{l}1.9 \\
1.9 \\
1.2 \\
0.86\end{array}$ & $\begin{array}{r}0.5 \\
0.6 \\
0.3 \\
<0.1\end{array}$ & $\begin{array}{l} \pm \\
\pm \\
\pm \\
\pm\end{array}$ & $\begin{array}{l}0.15 \\
0.17 \\
0.14 \\
0.05\end{array}$ & $\begin{array}{r}15 \\
14 \\
1.6 \\
0.9\end{array}$ & $\begin{array}{l} \pm \\
\pm \\
\pm \\
\pm\end{array}$ & $\begin{array}{l}1.6 \\
1.5 \\
0.36 \\
0.17\end{array}$ & $\begin{array}{r}44 \\
42 \\
5.0 \\
2.6\end{array}$ & $\begin{array}{l} \pm \\
\pm \\
\pm \\
\pm\end{array}$ & $\begin{array}{l}4.8 \\
4.6 \\
1.1 \\
0.54\end{array}$ \\
\hline NOTS 6 & $14 N-03 W-07$ DAA & $\begin{array}{l}106.2 \\
141.0 \\
180.8 \\
180.8 \\
222.8 \\
276.2 \\
296.2 \\
327.1 \\
475.1\end{array}$ & $\begin{array}{r}3.9 \\
4.4 \\
8.1 \\
6.8 \\
7.7 \\
14 \\
9.7 \\
3.5 \\
110\end{array}$ & $\begin{array}{l} \pm \\
\pm \\
\pm \\
\pm \\
\pm \\
\pm \\
\pm \\
\pm \\
\pm\end{array}$ & $\begin{array}{l}0.47 \\
0.54 \\
1.0 \\
0.98 \\
0.93 \\
1.6 \\
1.3 \\
0.38 \\
12\end{array}$ & $\begin{array}{r}0.2 \\
<0.1 \\
<0.1 \\
<0.1 \\
0.1 \\
0.2 \\
0.7 \\
<0.1 \\
5.1\end{array}$ & $\begin{array}{l} \pm \\
\pm \\
\pm \\
\pm \\
\pm \\
\pm \\
\pm \\
\pm \\
\pm\end{array}$ & $\begin{array}{l}0.07 \\
0.04 \\
0.06 \\
0.08 \\
0.07 \\
0.11 \\
0.29 \\
0.03 \\
0.70\end{array}$ & $\begin{array}{r}1.8 \\
1.8 \\
2.3 \\
2.2 \\
2.3 \\
6.0 \\
4.7 \\
1.4 \\
110\end{array}$ & $\begin{array}{l} \pm \\
\pm \\
\pm \\
\pm \\
\pm \\
\pm \\
\pm \\
\pm \\
\pm\end{array}$ & $\begin{array}{r}0.26 \\
0.27 \\
0.41 \\
0.49 \\
0.39 \\
0.83 \\
0.81 \\
0.18 \\
12\end{array}$ & $\begin{array}{c}5.5 \\
5.3 \\
7.0 \\
6.6 \\
7.0 \\
18 \\
14 \\
4.1 \\
320\end{array}$ & $\begin{array}{l} \pm \\
\pm \\
\pm \\
\pm \\
\pm \\
\pm \\
\pm \\
\pm \\
\pm\end{array}$ & $\begin{array}{l}0.81 \\
0.82 \\
1.3 \\
1.5 \\
1.2 \\
2.5 \\
2.5 \\
0.56 \\
35\end{array}$ \\
\hline NOTS 7 & $09 N-02 W-29 D C A$ & 262.7 & - & & - & - & & - & - & & - & - & & - \\
\hline NOTS $7 \mathrm{~A}$ & $09 N-02 W-29$ DCA & $\begin{array}{l}330.1 \\
407.5 \\
480.0 \\
480.0\end{array}$ & $\begin{array}{r}24 \\
3.6 \\
3.4 \\
\end{array}$ & $\begin{array}{l} \pm \\
\pm \\
\pm\end{array}$ & $\begin{array}{l}3.0 \\
0.56 \\
0.59 \\
-\end{array}$ & $\begin{array}{l}1.0 \\
0.1 \\
0.3 \\
-\end{array}$ & $\begin{array}{l} \pm \\
\pm \\
\pm\end{array}$ & $\begin{array}{c}0.28 \\
0.10 \\
0.17 \\
-\end{array}$ & $\begin{array}{r}12 \\
1.8 \\
1.9 \\
\end{array}$ & $\begin{array}{l} \pm \\
\pm \\
\pm\end{array}$ & $\begin{array}{l}1.5 \\
0.35 \\
0.40 \\
-\end{array}$ & $\begin{array}{r}35 \\
5.4 \\
5.8 \\
-\end{array}$ & $\begin{array}{l} \pm \\
\pm \\
\pm\end{array}$ & $\begin{array}{l}4.6 \\
1.1 \\
1.3 \\
-\end{array}$ \\
\hline
\end{tabular}


Table 12. - Concentrations of selected radionaclides in water from NOTS test holes-Cont inued

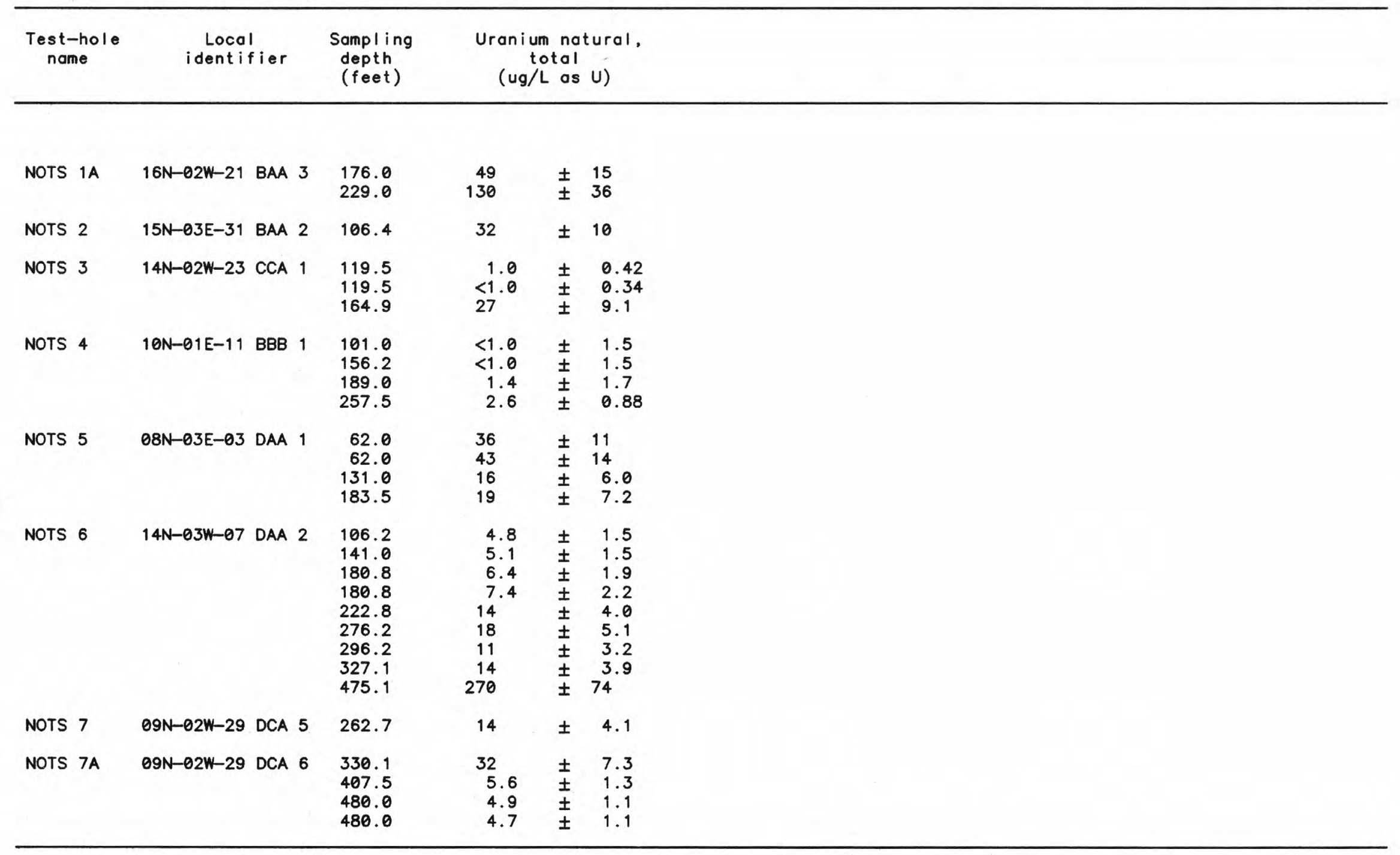


Table 13. - $\delta$-values in permil for stable isotopes in water from NOTS test holes

[Sampling depth, center of sampling interval below land surface; PDB, Peedee Belemnite; SMOW; Standard Mean Ocean Water; CDT, Canyon Diablo Troilite; $\delta$-value in permil, ((isotope ratio in sample minus ratio in standard) divided by ratio in standard) multiplied by 1,$000 ;$ - indicates no data are available. All samples analyzed by the National Water Quality Laboratory of the U.S. Geological Survey]

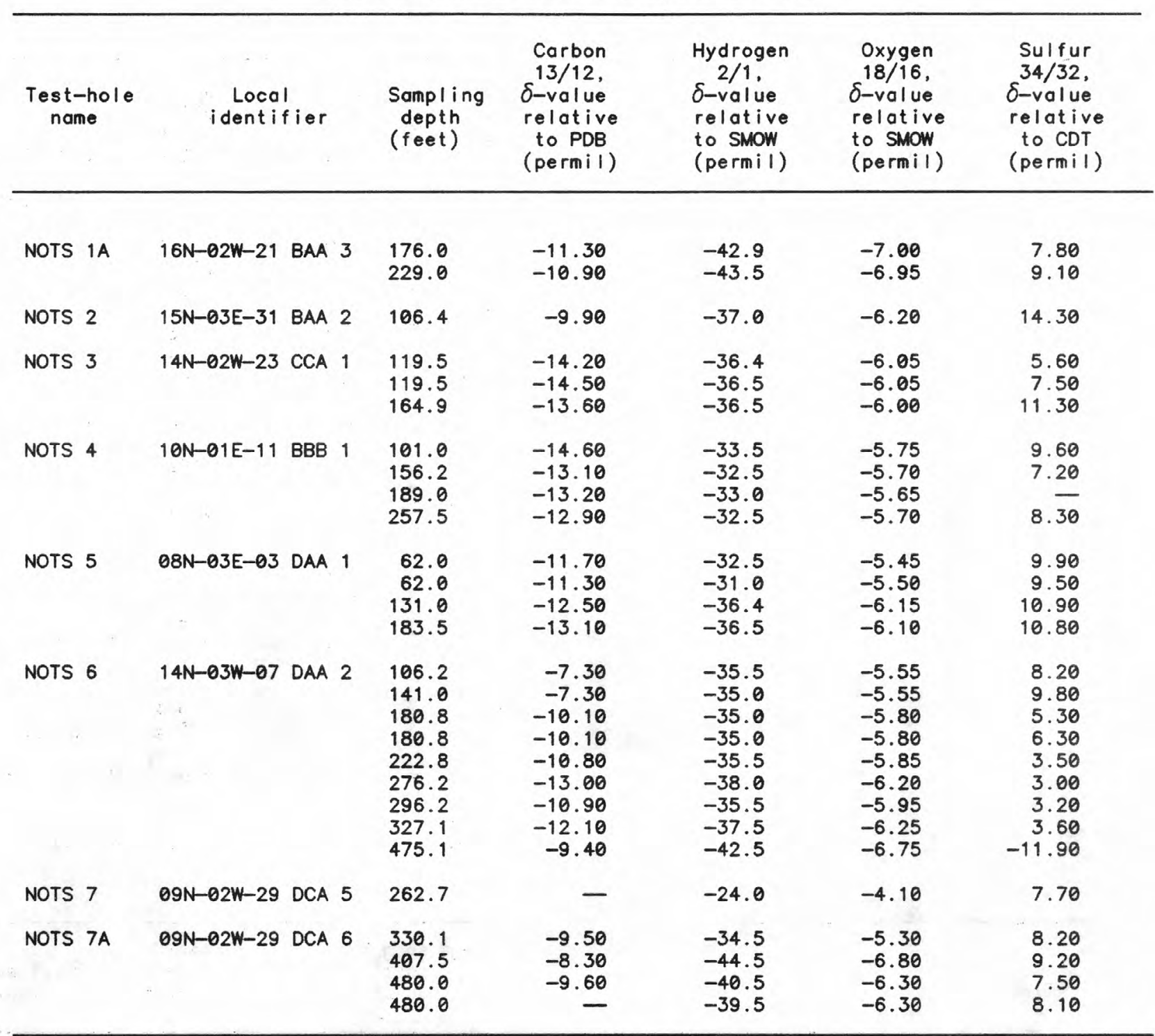


